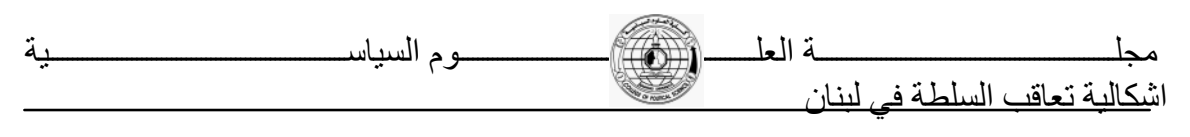

\title{
اشكالية تعاقب السلطة في لبنان
}

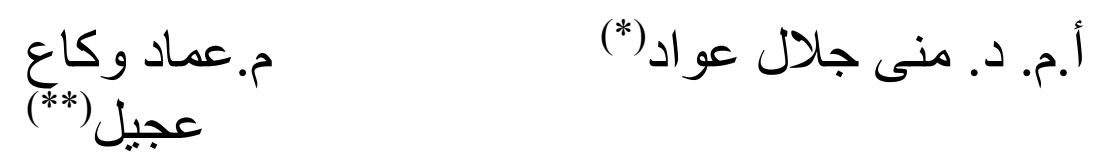

$$
\text { ملخص البحث }
$$

تُعَد السلطة السياسية في لبنان، هدفاً أساسياً لكل تنظيم سياسي، سواءأ كان

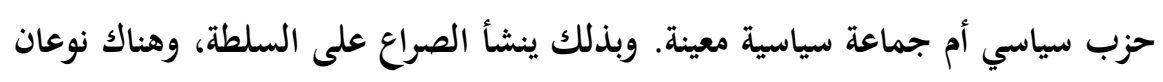

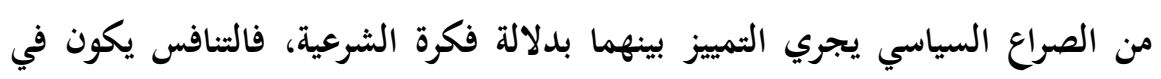

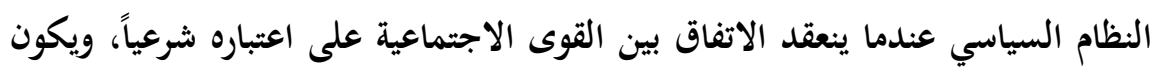

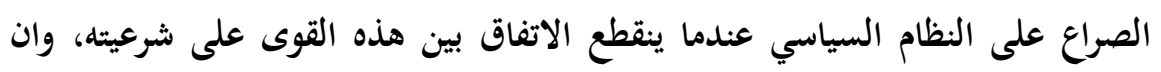

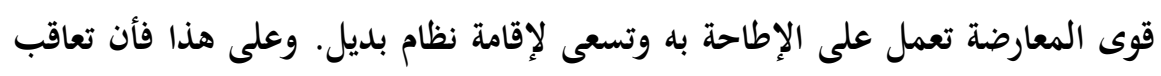

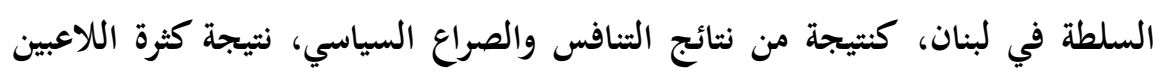
الاقليميين والدوليين على الساحة اللبنانية.

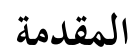

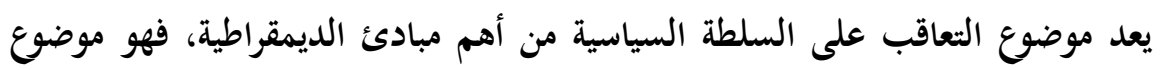

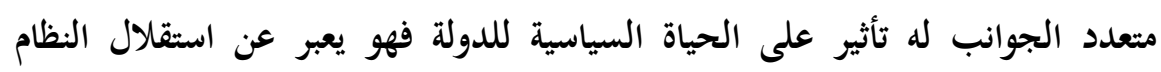

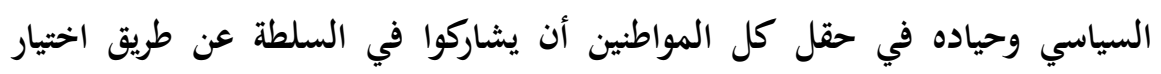

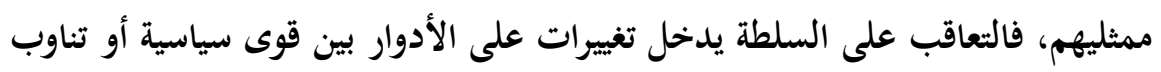

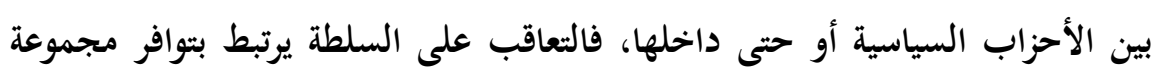

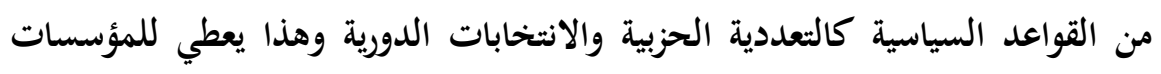
السياسية حصانة واستقرار، اذ يشير موضوع التعاقب على السلطة إلى عملية تبادل

(") كلية العلوم السياسية/ جامعة بغداد.

(") 


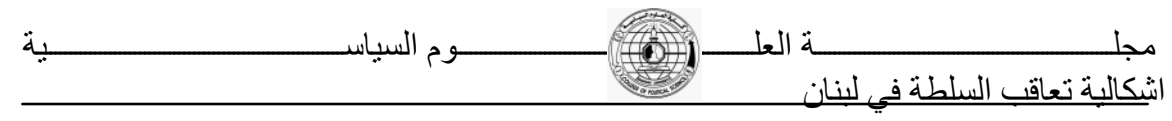

الأدوار بين مختلف القوى السياسية، فالدول على اختلاف أنظمتها السياسية تتبع آلية معينة سلمية أو غير سلمية حتى تصل إلى تحقيق الاستقرار السياسي للدفع بعجلة التنمية، تكمن أهمية موضوع التعاقب على السلطة في جوهر العملية السياسية لأي نظام سياسي قائم على أسس أصيلة لممارسة السلطة من شأنه توطيد العلاقة بين مكونات

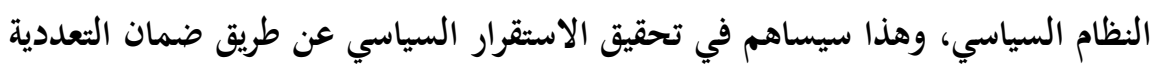
وضمان حكم الأغلبية عن طريق انتخابات دورية، وهذا كله يصب في دعم الديمقراطية

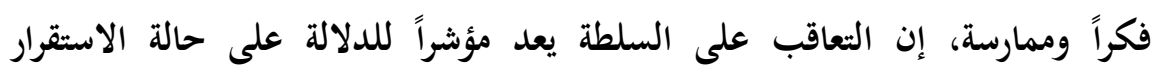
السياسي فهو مقياس دقيق لمدى التطور الديمقراطي، ويمثل مبدأ بنائي ومؤسسي للعملية الديمقراطية.

ان الفكرة الاساسية لمشكلة البحث تتعلق بأزمة تعاقب السلطة في لبنان، فهذه

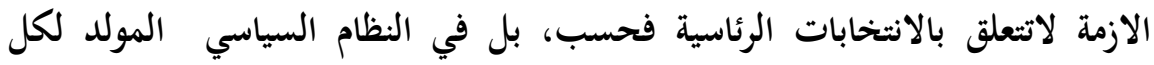

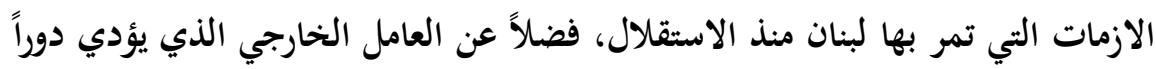
كبيراً ومؤثراً في الحياة السياسية في لبنان.

يحاول البحث الانطلاق من فرضية مفادها: ان التعاقب على السلطة في لبنان مبني على قاعدتين رئيسيتين هما: الإطار الدستوري الخاص، وجهات سياسية ترتبط بهذا الإطار الدستوري على أسس معينة.

اعتمد البحث مناهج عدة للوصول الى هدف البحث منها: منهج التحليل النظمي النه

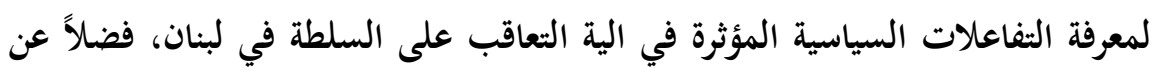
المنهج الثاريخي.

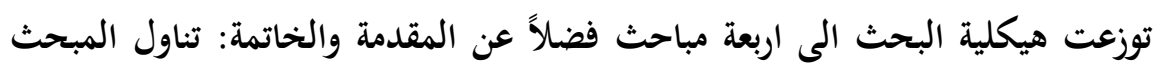
الاول حيثيات وآليات التعاقب على السلطة في لبنان، فيما تناول المبحث الثاني:

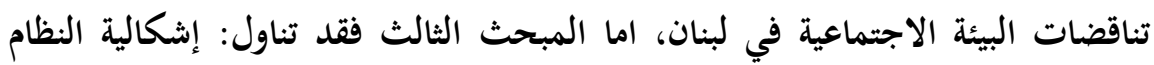
السياسي في لبنان، في حين تناول المبحث الرابع: السياسات الإقليمية والدولية وتعاقب السلطة في لبنان. 


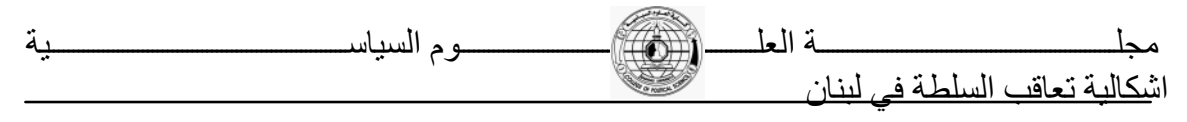

$$
\text { المبحث الاول: حيثيات وآليات التعاقب على السلطة }
$$

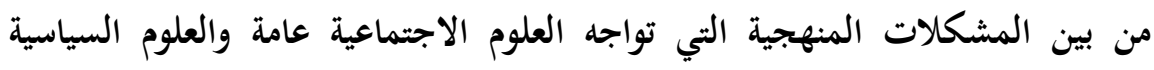

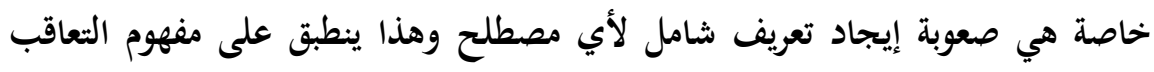

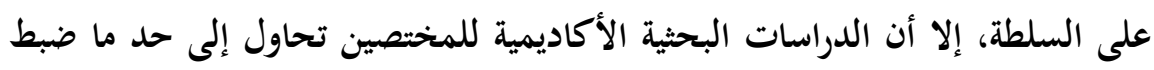

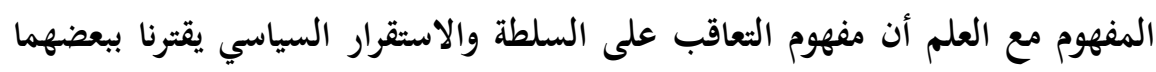

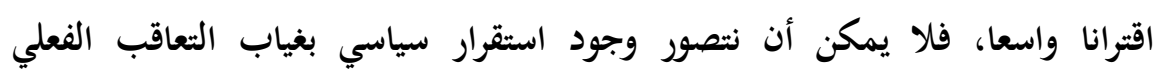

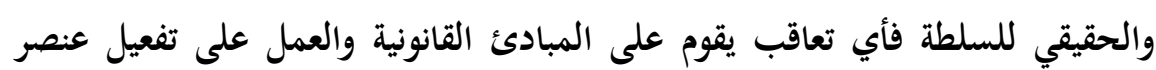

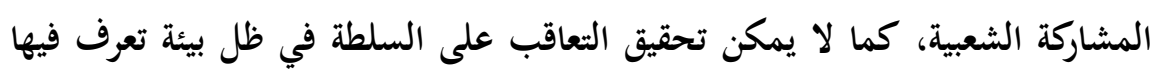

$$
\text { مشكلات وأزمات سياسية. }
$$

المطلب الاول: تعريف التعاقب على السلطة.

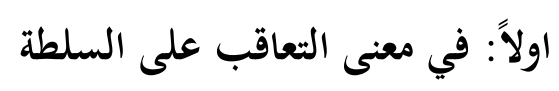

إن محاولة تعريف مفهوم التعاقب السلطة لاتخلو من صعوبات التعاق وإشكالا تترتبط بتعدد

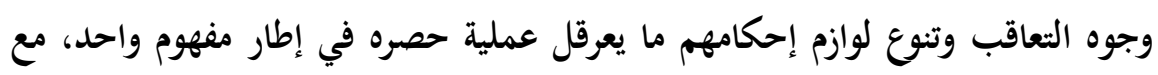
ذلك وبشكل عام يعني هذا المبدأ: إن تتعاقب أو تتناوب على السلطة القوى السياسية

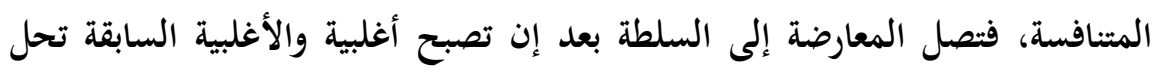

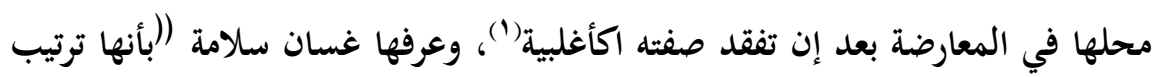

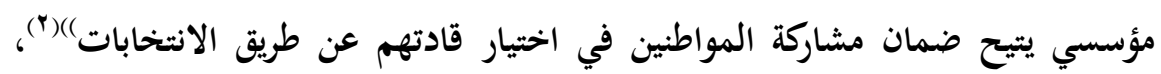

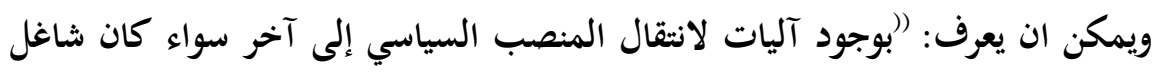

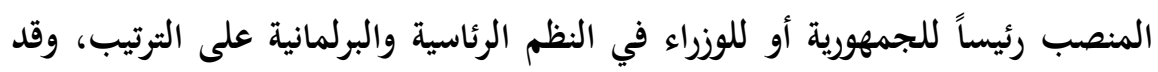

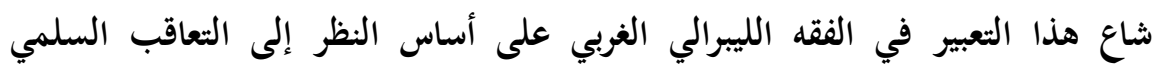

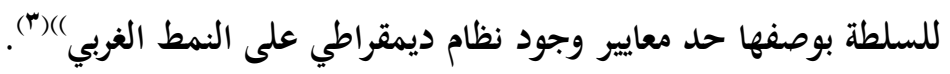




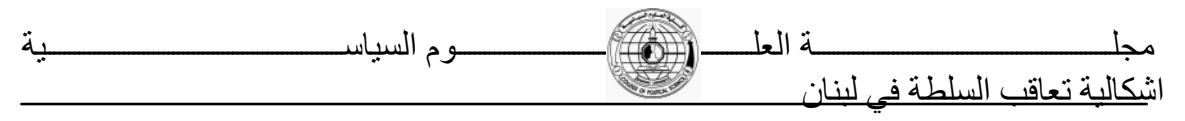

ورغم إن مبدأ التعاقب على السلطة هو مبدأ دستوري تتم مراعاته من الدول الديمقراطية

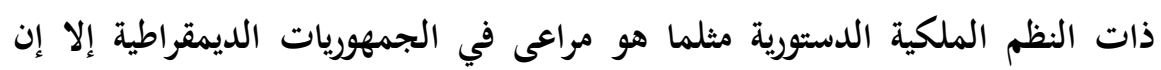

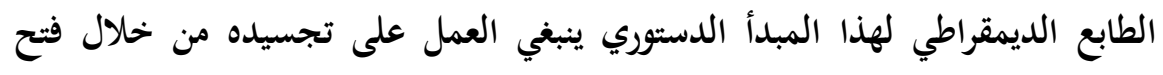

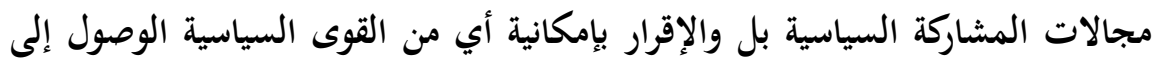

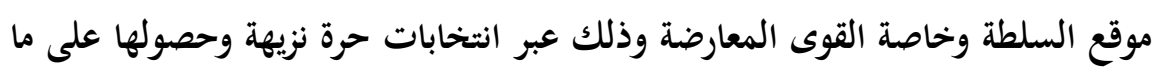

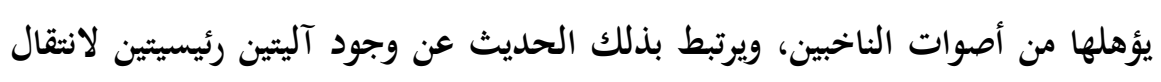

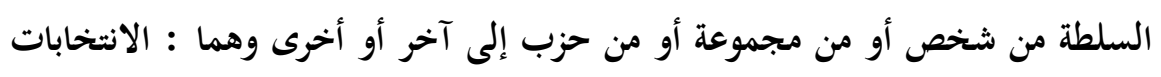

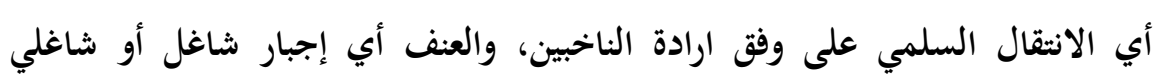

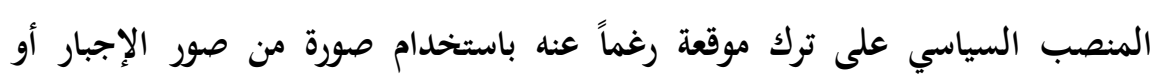

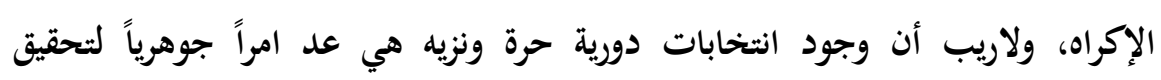
التعاقب السلمي للسلطة (\&). ان التعاقب على السلطة بين القوى السياسية الفاعلة في الساحة السياسية كما يقول

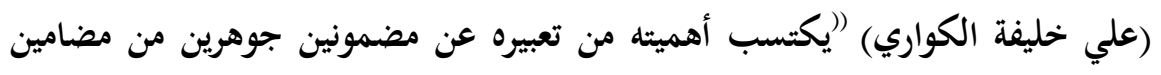

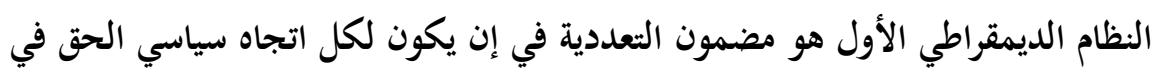

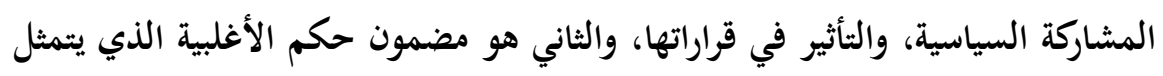

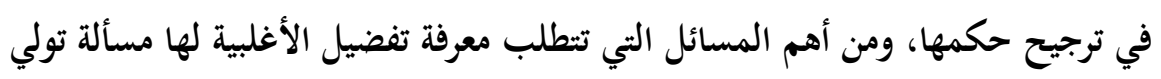
السلطة باعتبار الشعب مصدر السلطات وتطبيق المبدأ حكم الأغلبية)(ه).

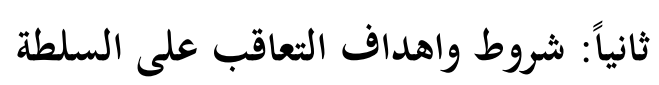
يتطلب ترسيخ مبدأ التعاقب على السلطة مجموعة من الشروط منها ("):

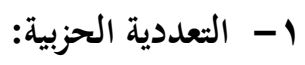

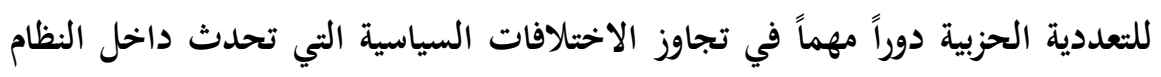

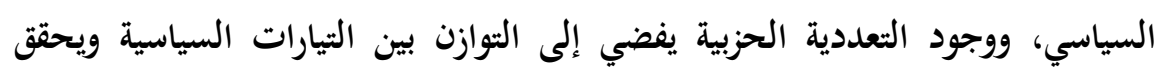

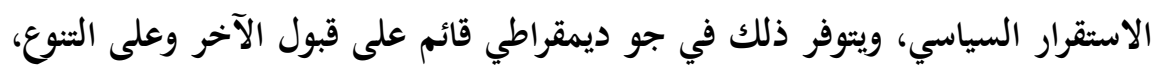

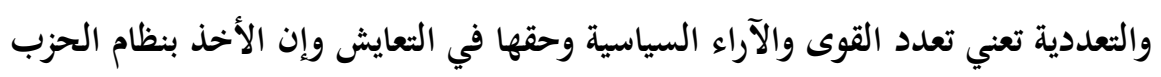




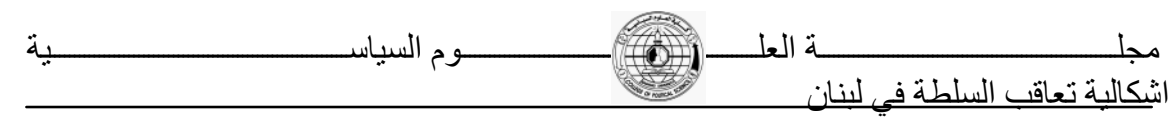

الواحد من شأنه أن يحد من حرية الاختيار ما دامت السلطة بيد الحزب المهيمن وبهذا

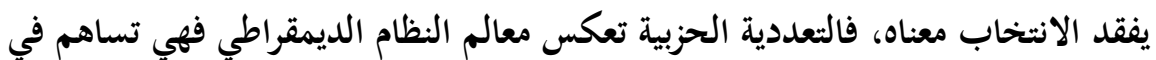

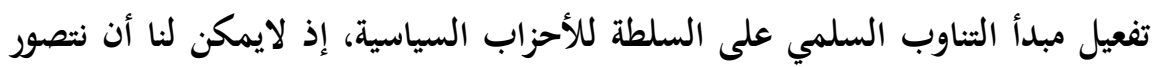

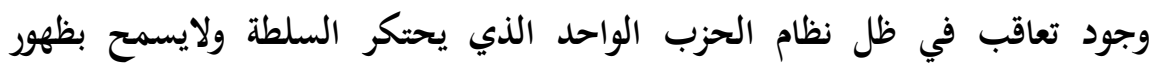

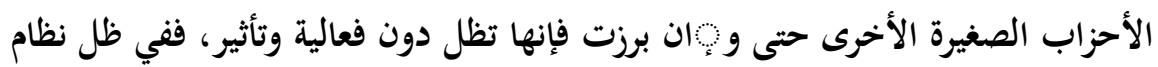

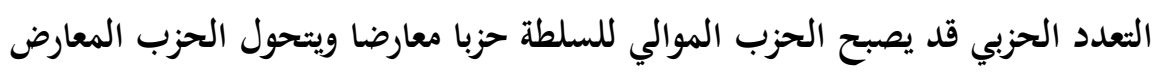

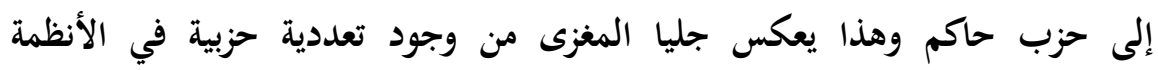

$$
\text { r- الانياسية. }
$$

حتى تكون عملية التعاقب على السلطة سلمية وشرعية يتم اللجوء للانتخاب كأداة

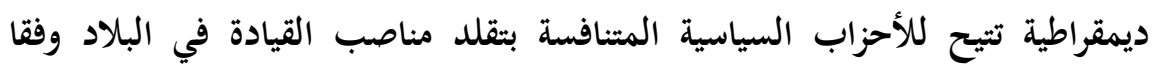

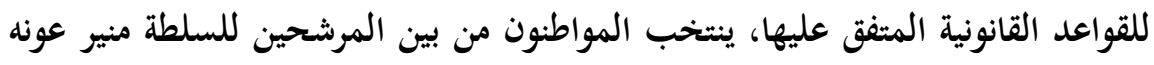

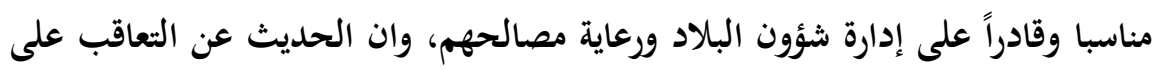

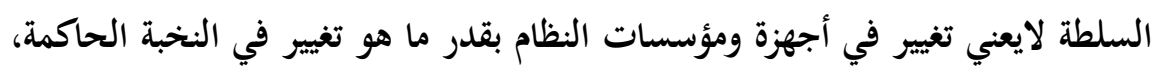

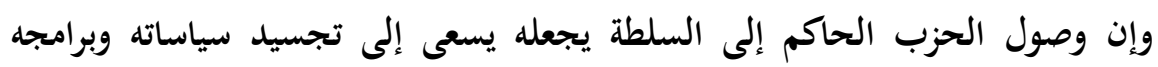
وينعكس ذلك في مؤسسات الدولة وأجهزتها. المطلب الثاني: اليات التعاقب على السلطة

هنا كمجموعة من الآليات للتعاقب على السلطة منها الآليات السلمية وغير السلمية.

$$
\text { اولاًا: الآليات السلمية: وتشمل: }
$$

أحد الآليات المشروعة والسلمية لتحقيق تعاقب سلمي على السلطة ـالانتخاب هو

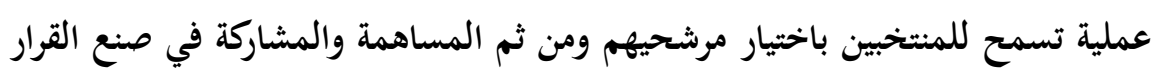

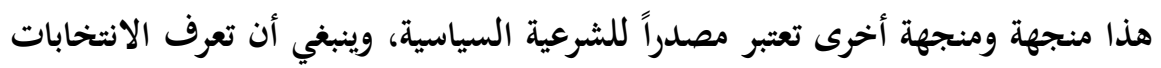




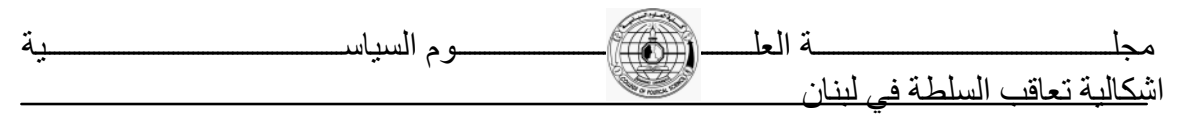

الحرية والنزاهة حتى نستطيع النكلم عن التعاقب السلمي للسلطة، وهناك مجموعة من

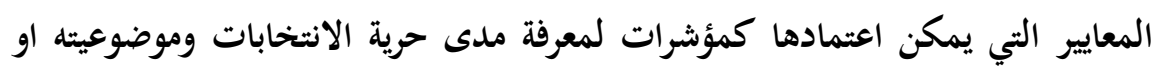

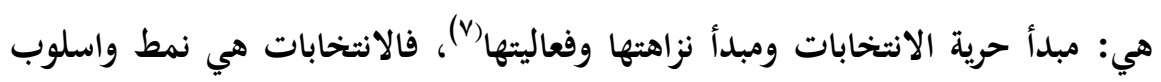

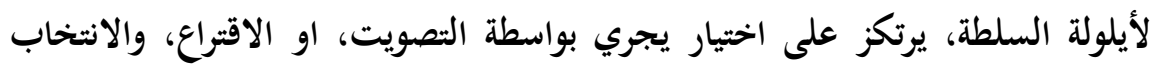

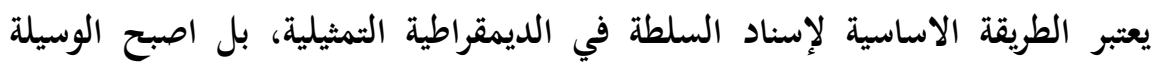

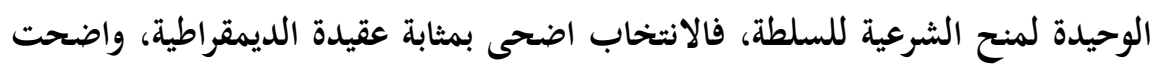

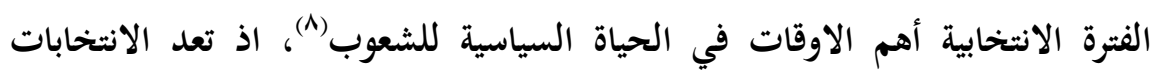

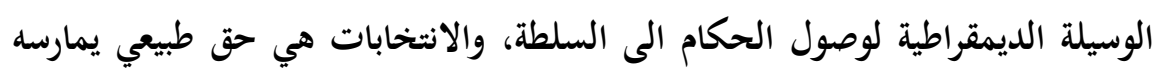

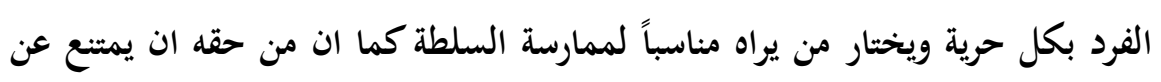

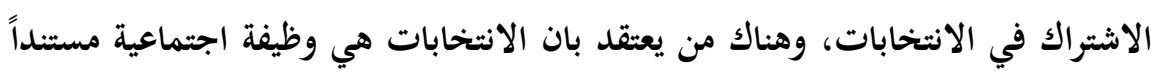

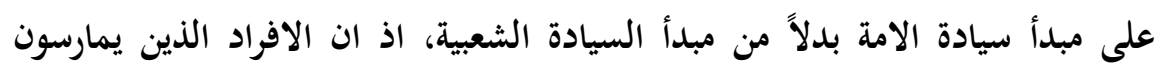

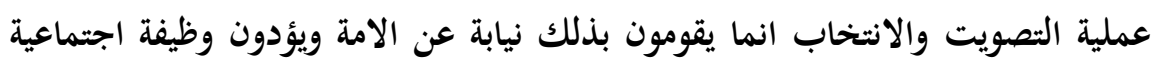

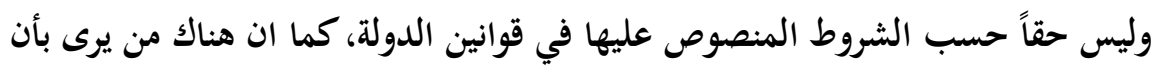
الانتخاب ليس بحق ولا وظيفة اجتماعية وانما هو سلطة قانونية مصدرها الاساسي التياسي

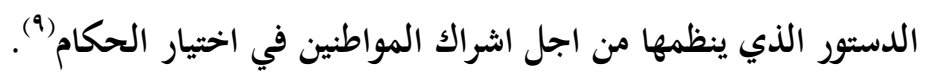

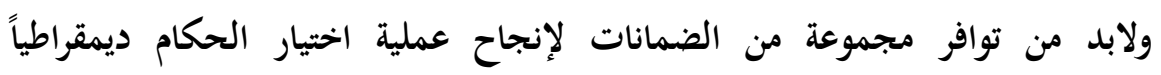

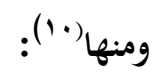

أ-كفالة الحريات العامة: كحرية الاختيار والتعبير والعمل والتجمع والتنقل في ظل

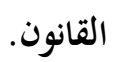

ب - تمتع المؤسسات السياسية والدستورية بمستوى من الثبات الدستوري والاستقرار

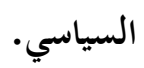

ج - تمثيل المؤسسات السياسية والدستورية لعموم المجتمع وليس لفئة اجتماعية محددة. 


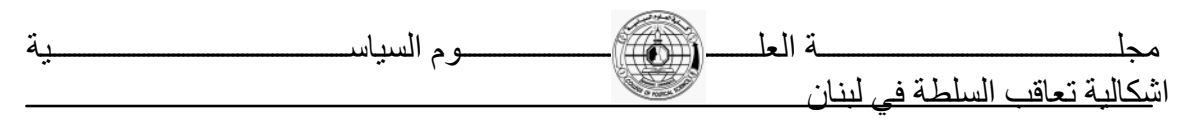

د - الإقرار بوجود المعارضة ومشاركتها الفاعلة في عملية التنافس السلمي على

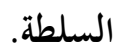

هـ - المساواة التامة بين النخب الحاكمة وبين خصومهم السياسيين خصوصا فيما يتعلق بإتاحة الفرص أمامهم للعمل بين صفوف الجماهير والوصول إليهم بحرية.

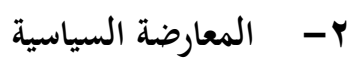

من ناحية المبدأ يعد البرلمان بالنسبة للمعارضة السياسية المكان السياسي المميز لما

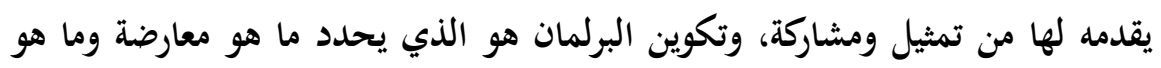

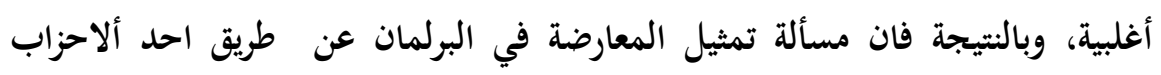

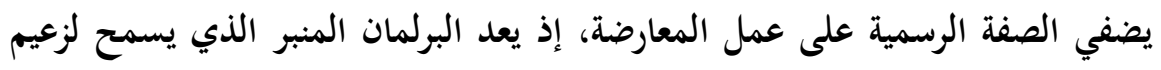

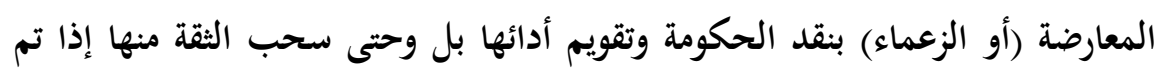

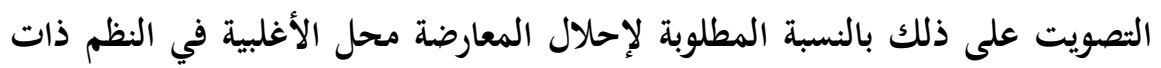

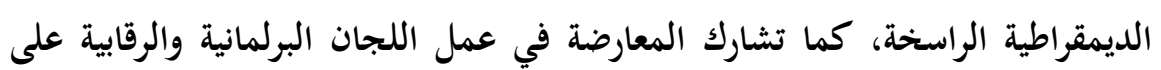

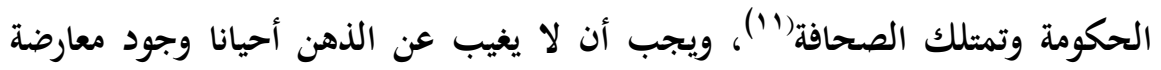

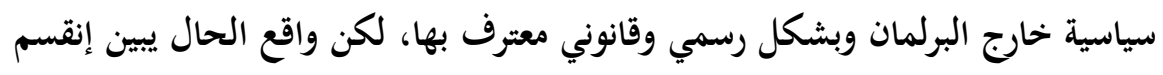

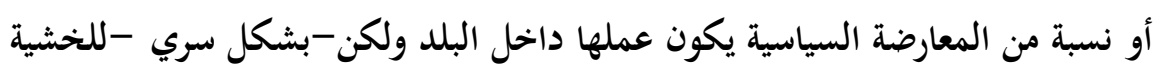

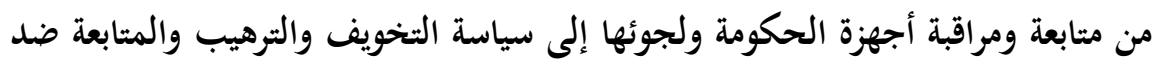

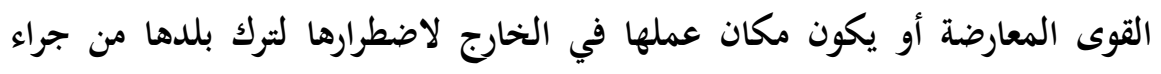

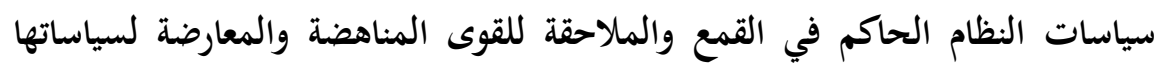

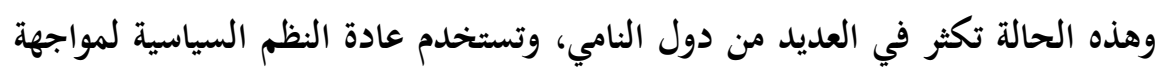

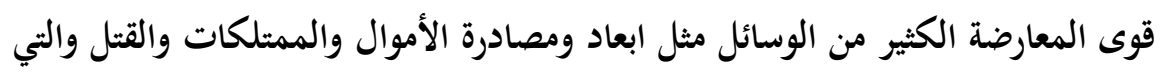

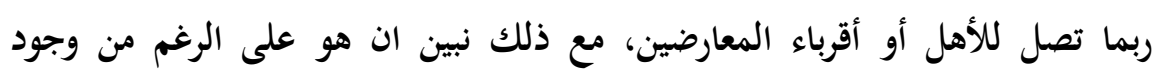

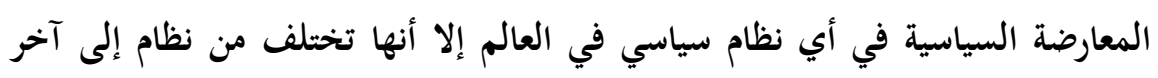




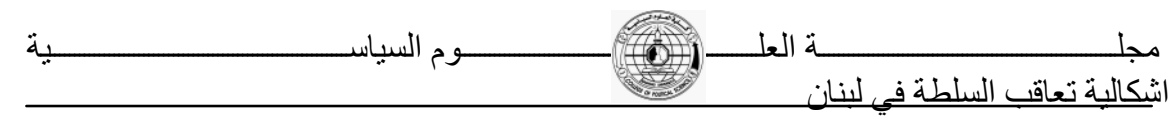

بحسب طبيعة النظام السياسي الذي تكون موجودة فيه وحسب نظرة ذلك النظام لتلك المعارضة، فمن حيث وضعها القانوني يمكن تمييز نوعين منها : المعارضة غير الشرعية التي تعني : القوى التي ترفض النخبة الحاكمة دخولها في إطار النظام السياسي وتمنعها قانونيا "ودستوريا "من المشاركة، والمعارضة الشرعية : وهي القوى التي تعترف النخبة

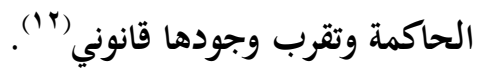

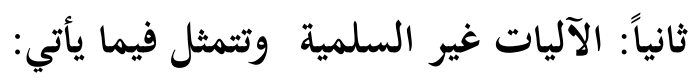
الانقلابات العسكرية والثورات التي تبتعد على الشرعية والقوانين الدستورية لتعاقب

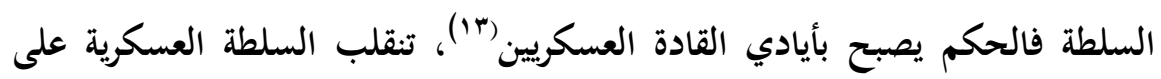

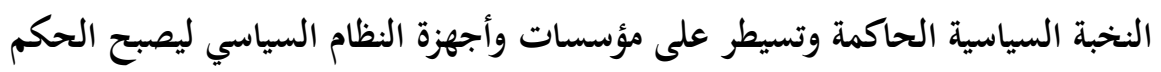
عسكري الا يتماشى ويتنافى ومبادئ الحكم الديمقراطي لأن الوصول إلى السلطة لم يكن على وفق المرجعية القانونية.

ثالثاً: معوقات التعاقب السلمي على السلطة: قد يقف في سبيل تفعيل مبدأ التعاقب على السلطة مجموعة من العراقيل والمعوقات وتتمثل في (ع) (1):

1-وجود اختلاف في القواعد والقوانين الدستورية وعدم وجود ضوابط محددة. r-الائتلاف الحكومي غير المتجانس الذي يخلق عدم استقرار على مستوى السلطة. r - الثفرد بالسلطة من طرف نخبة سياسية معينة ولفترة طويلة من الزمن. ع -تراجع دور المشاركة الشعبية في الحياة السياسية. ه-كثرة الأزمات الداخلية في النظام السياسي التي من شأنها أن تؤثر على مستقبل الدولة الدياه

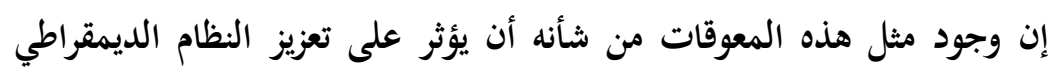

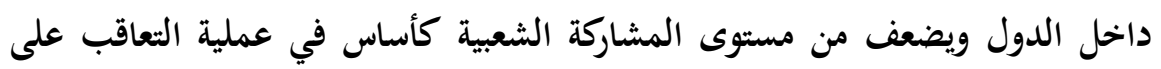

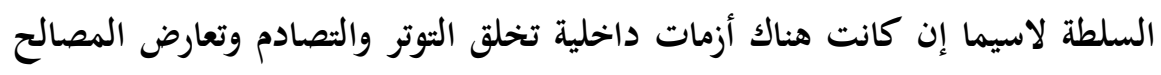
بين الفئات التي يتكون منها النظام، والذي يؤثر بالسلب على عمل مؤسسات التهات الجهاز 


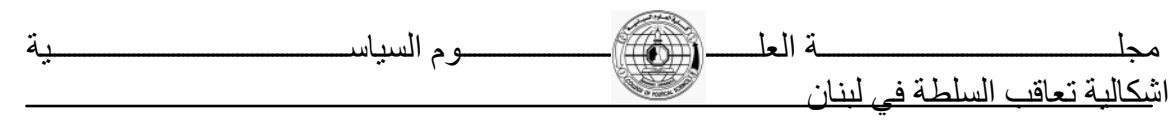

الحاكم. على ضوء ما تقدم يمكن القول إن تعاقب السلطة من أهم عناصر وركائز

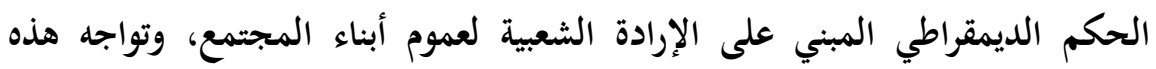

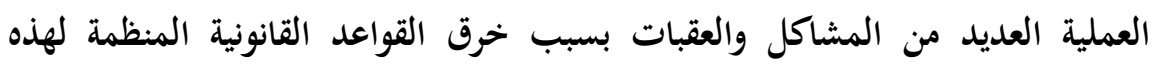

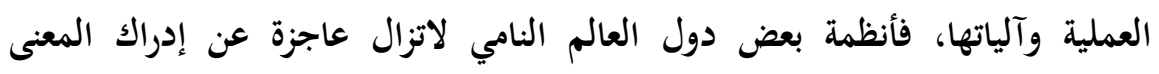
الصحيح للسلطة في كونها سلطة الدولة وليست سلطة الحكام وانه لايمكن احتكارها من قبل قوة اجتماعية - سياسية واحدة، وحيث إن من مهام الدولة الحديثة تحقيق

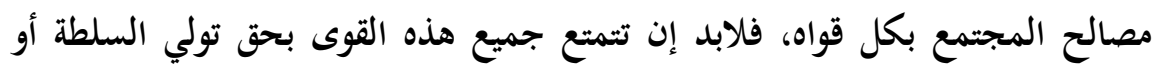

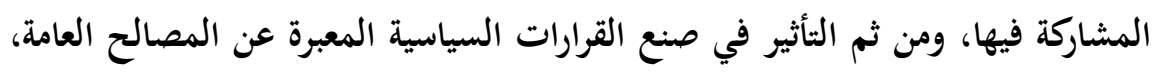

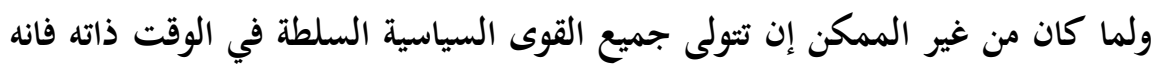

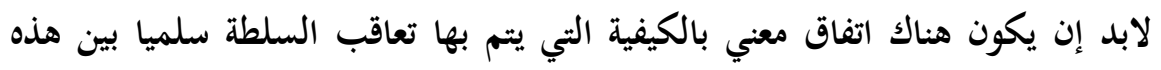

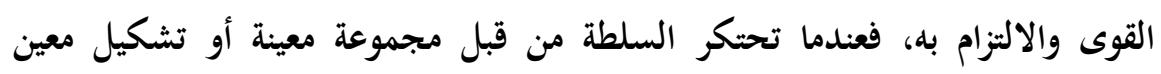

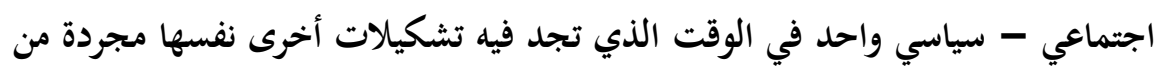

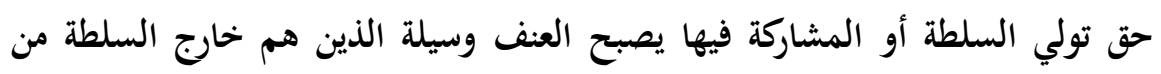

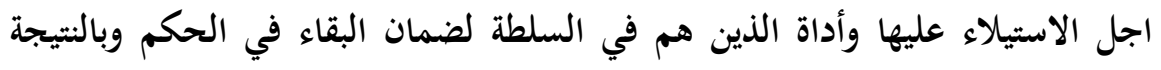

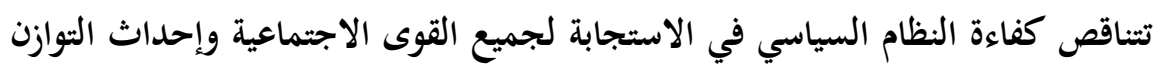

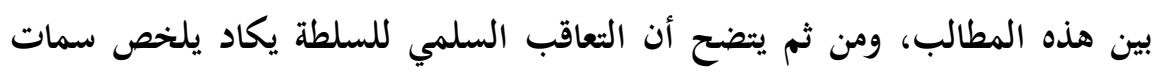

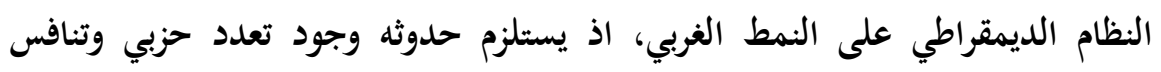
سياسي حقيقي وانتخابات دورية حرة ونزيهة ورأي عام قوي وقادر على الثأثير ووسائل إعلام تقوم بدور رقابي فاعل في محاسبة القائمين على السلطة (10). المبحث الثاني: تناقضات البيئة الاجتماعية في لبنان

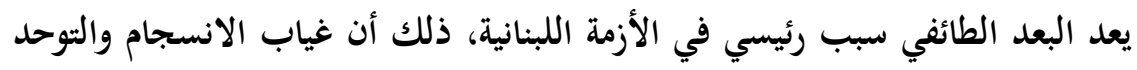

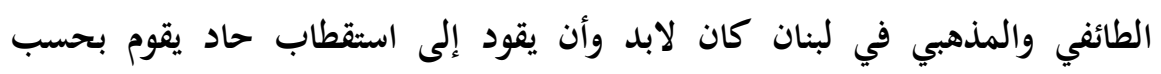




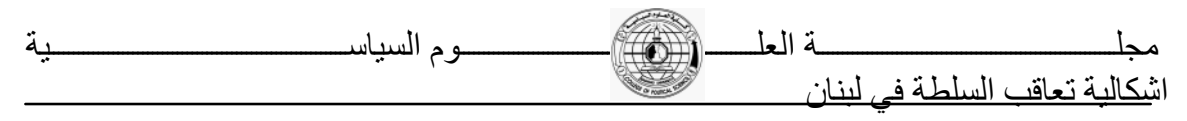

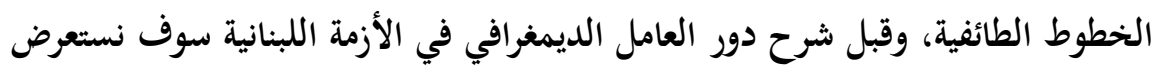
أهم ما يتميز به المجتمع اللبناني (الثركيبة السكانية).

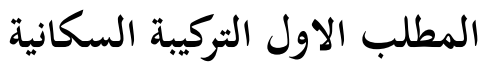

شكلت لبنان عبر التاريخ، وبفضل موقعها وطبيعتها الجغرافية مكاناً تلتقي فيه التهبه

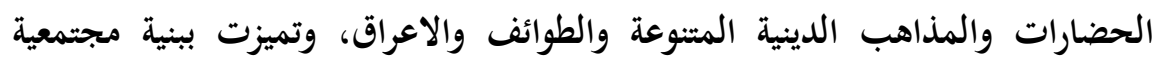
معقدة جعلت قضية العيش المشترك فيها بين الجماعات المختلفة محور حياتها

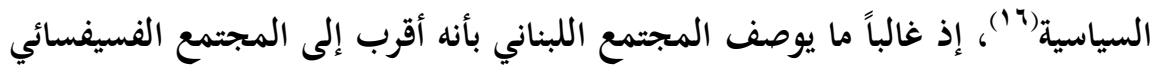

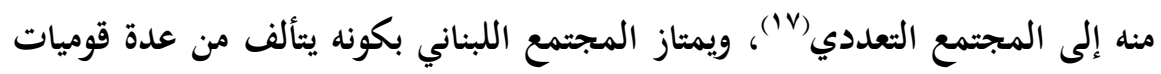

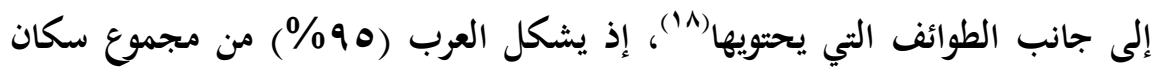

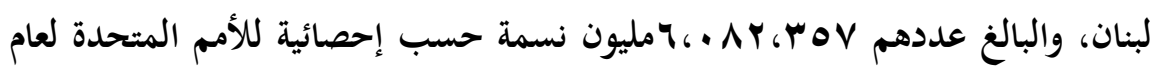

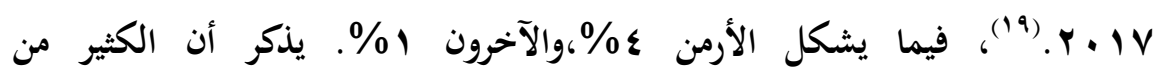

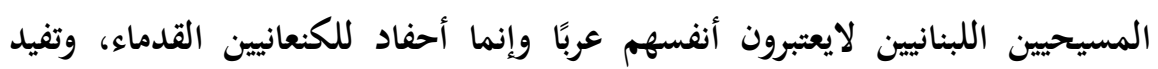

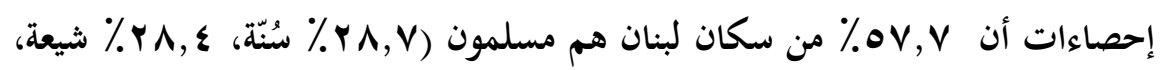

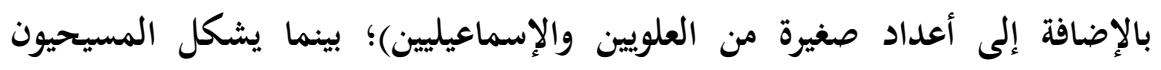

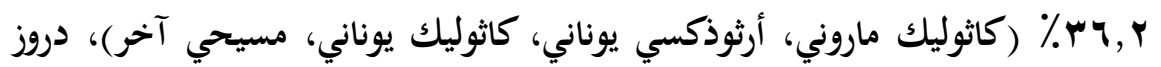

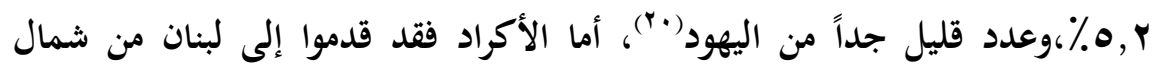

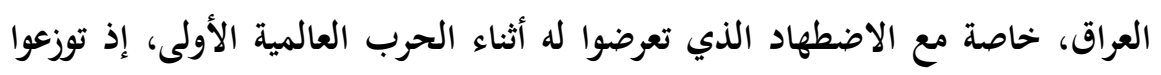

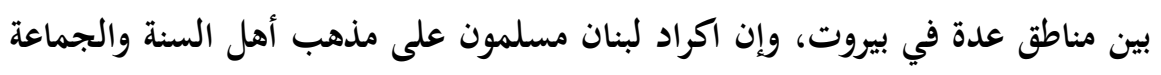

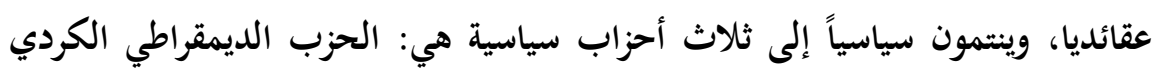

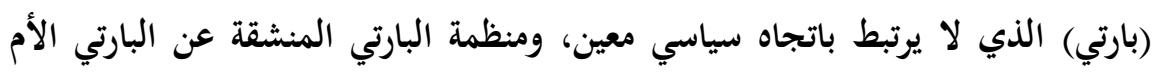

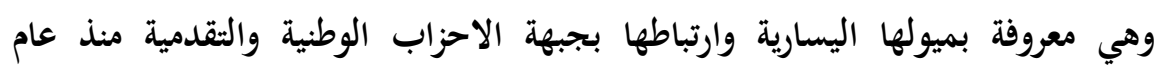

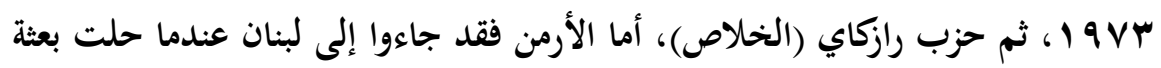

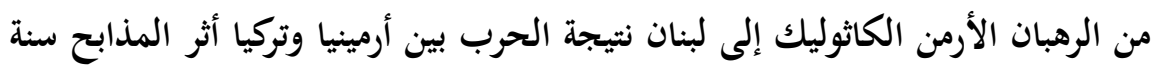

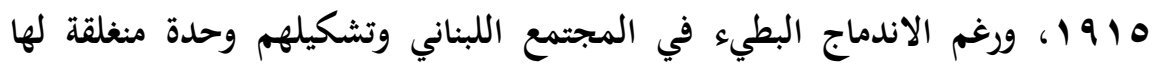




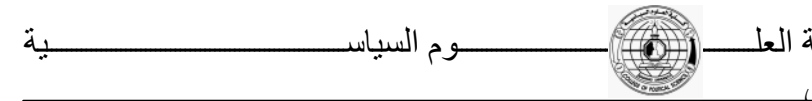

اثيكالبة تعاقب السلطة في لبنان

مدارسها وأنديتها وصحفها وأحزابها، إلا أن الأرمن انتقلوا إلى المؤسسات الصناعية والشركات التجارية.(1) ويمكن تصنيف سكان لبنان إلى مجموعتين دينيتين كبيرتين: إسلامية ومسيحية، وهناك أقلية يهودية تبلغ قرابة 5000 نسمة وأقليات دينية أخرى صغيرة، أما الطوائف المعترف بها رسميا فعددها 18 طائفة.(r) ينظر الى جدول

(1) (1) (1)

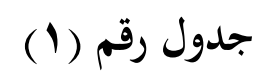

الطوائف المعترف بها في لبنان

\begin{tabular}{|c|c|}
\hline الطوائف الاسلامية & الطوائف المسيحية \\
\hline الطائفة السنية & البطريركية المارونية \\
\hline الطائفة الشيعية ( الجعفرية) & بطريركية الروم الأرثوذكسية \\
\hline الطائفة الدرزية & البطريركية الكاثوليكية الملكية \\
\hline الطائفة العلوية & البطريركية الأرمنية الأرثوذكسية \\
\hline \multirow{9}{*}{ الطائفة الاسماعيلية } & البطريركية الأرمنية الكاثوليكية \\
\hline & البطريركية السريانية الأرثوذكسية \\
\hline & البطريركية السريانية أو السريانية الكاثوليكية \\
\hline & الطائفة الشرقية النسطورية \\
\hline & البطريركية الكلدانية \\
\hline & الكنيسة اللاتينية \\
\hline & الكنيسة الإنجيلية \\
\hline & الكنيسة القبطية الأرثوذكسية \\
\hline & الكنيسة الأشورية \\
\hline
\end{tabular}

الجدول من إعداد الباحثين بالاعتماد على حسان حلاق، دراسات في المجتمع اللبناني، دار النهضة العربية للطباعة

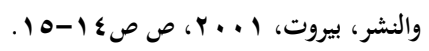




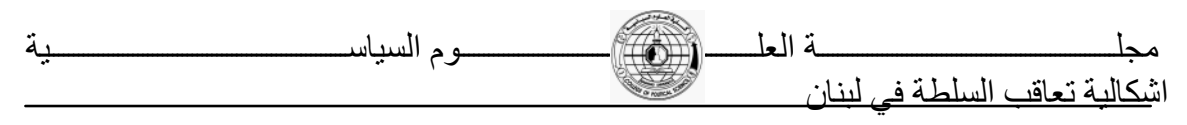

المطلب الثاني: الثركيبة السكانية والاستقرار السياسي

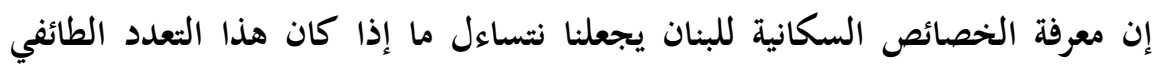

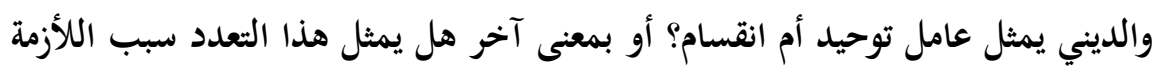

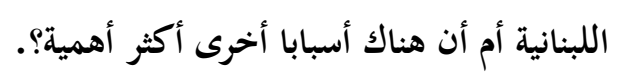

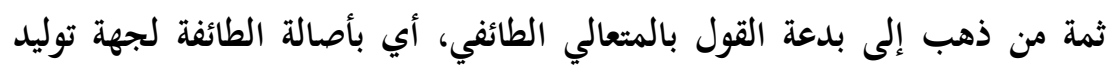

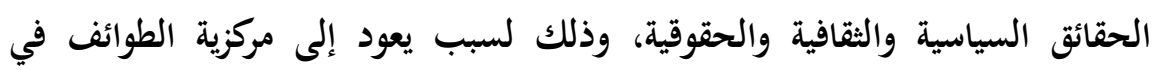

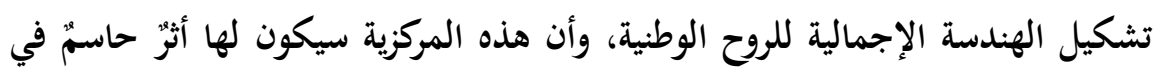

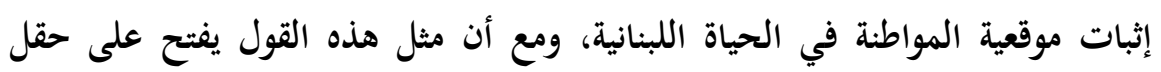

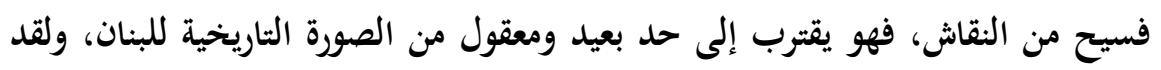

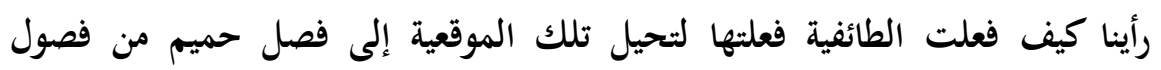
حركنها، ثم ليظهر لنا كم لسلطان الطوائف من شأن حاسم في تشكيل حياة مواطنيه،

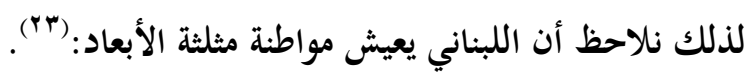
اولاً: فهو في سياق الانتماء الطائفي، مواطن في طائفته، يدين بالولاء لقياداتها المدنية والدينية.

ثانياً: وهو أيضًا يعيش مواطنة جغرافية مثلةلة بالرموز والتاريخ البعيد والحديث.

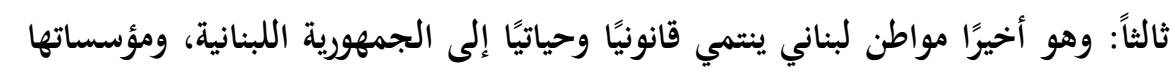
الدستورية. غير أن المفارقة المذهلة في هذا المقام، هي أن الجمهورية اللبنانية في الوقت الذي

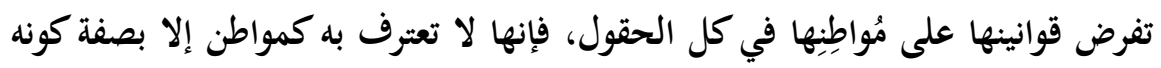

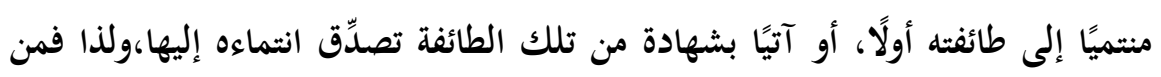

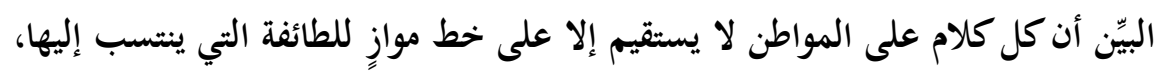

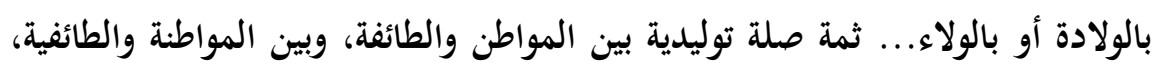

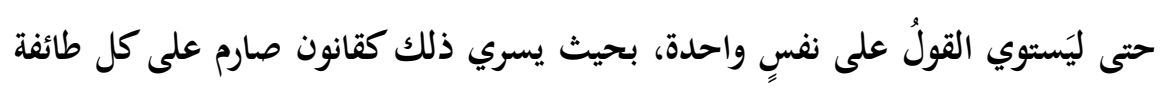

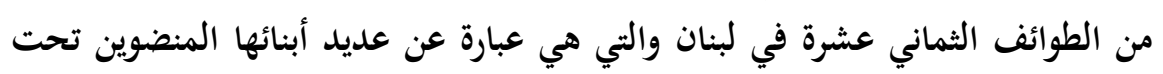




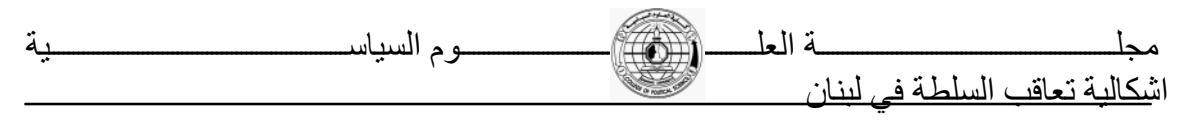

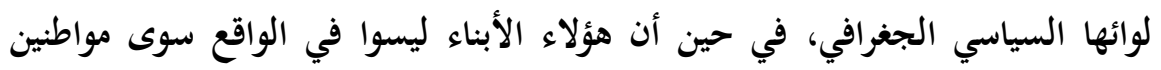

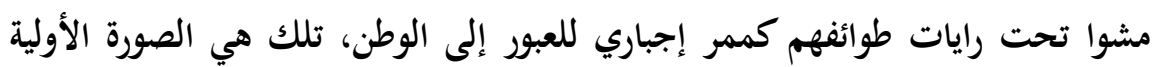

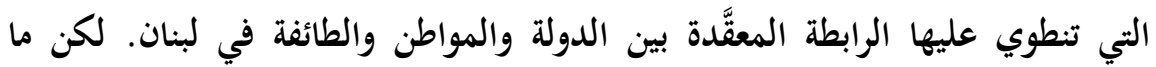

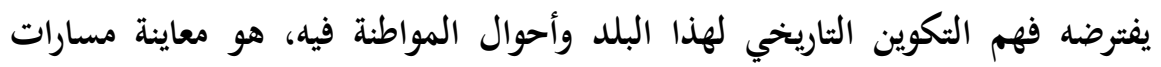
الطوائف، وأثر منظومتها السياسية والقانونية في ترسيخ البنيان الكلي للدولة الطائفية،

والمجتمع الطائفي (r).

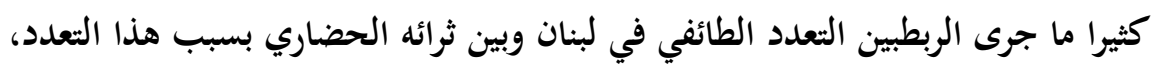

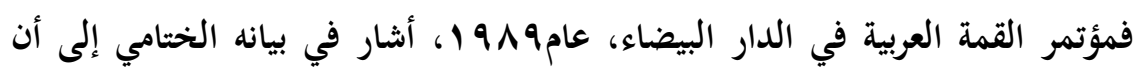

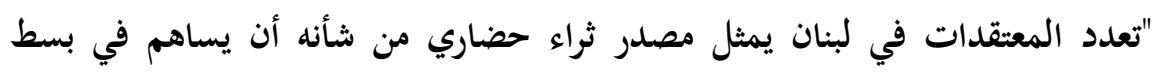

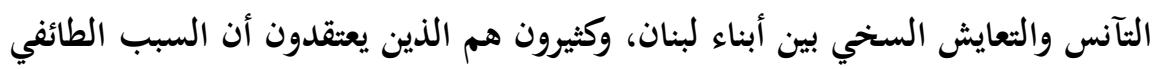

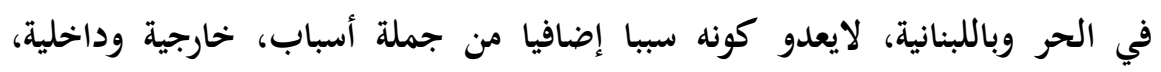

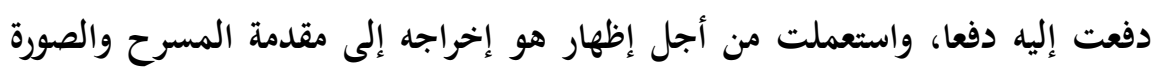
إمكانيات هائلة(10).

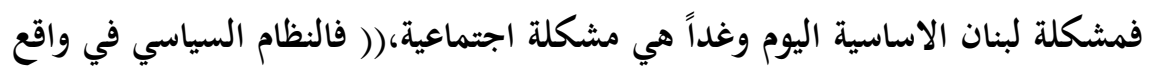

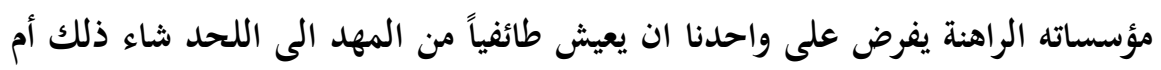

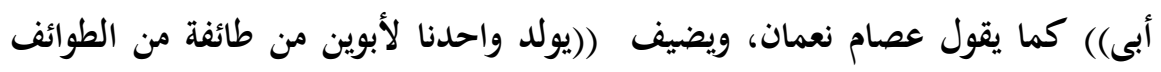

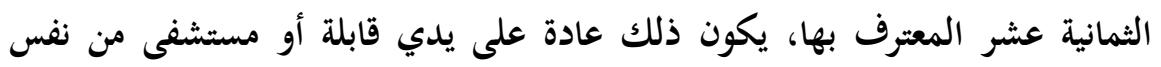

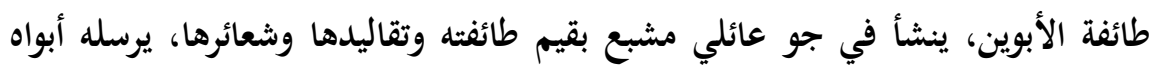

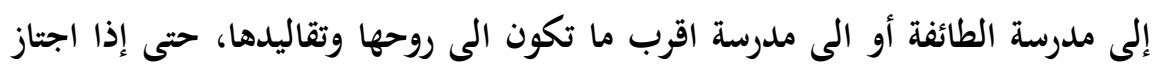

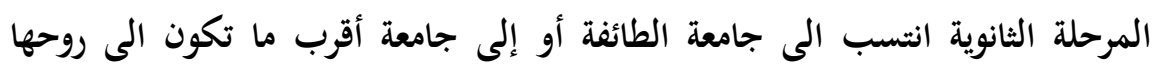

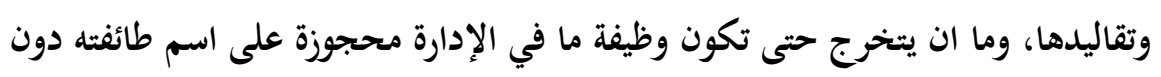

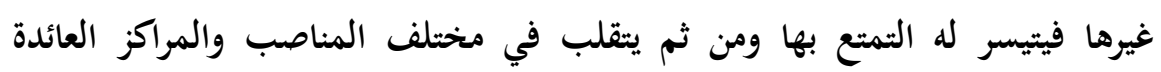

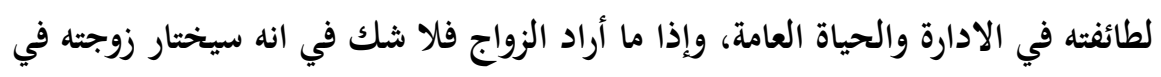

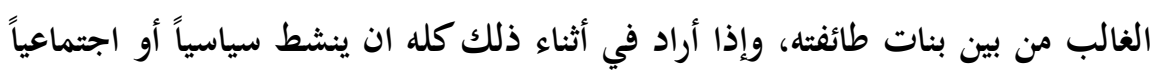




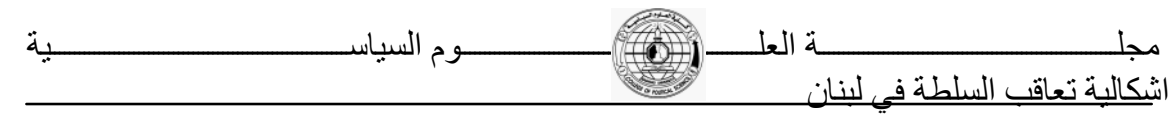

فبامكانه الانتساب إلى الحزب المعبر عن أهداف طائفته ومصالحها أو إلى الجمعية

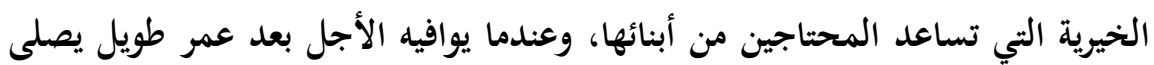

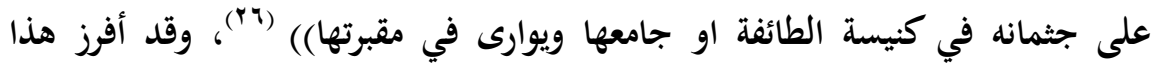

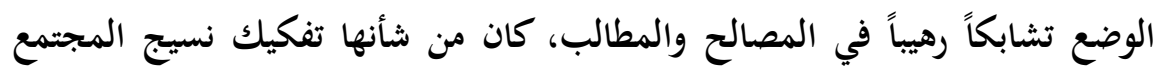

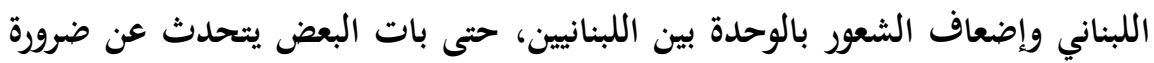

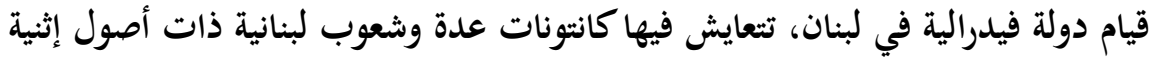
ودينية مختلفة، ومن ثم اصبح لكل طائفة مؤسساتها المدنية، التي تعمل على تقديم الخدمات لأبناء تلك الطائفة. (viv) فالطائفة في لبنان، تحاصر الفرد منذ ولادته بدءا بالعائلة مرورا بالعادات والتقاليد

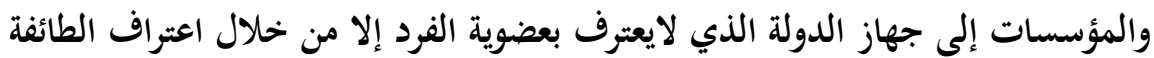

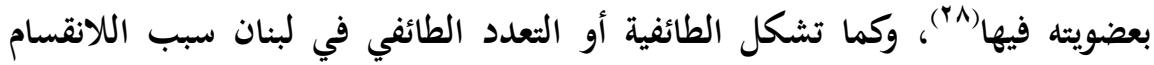

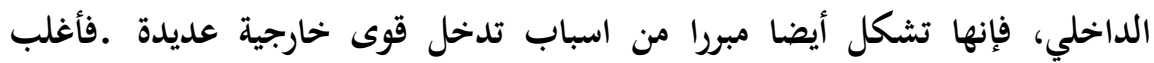
الطوائف في لبنان ترتبط ارتباطات سياسية بدول أجنبية، فمثلا المسيحيون ولاسيما

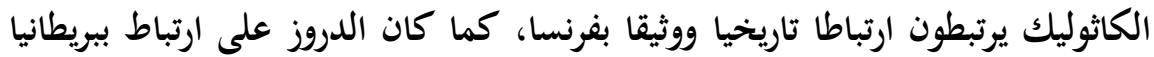

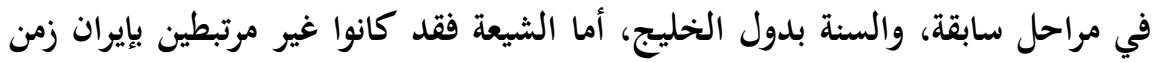

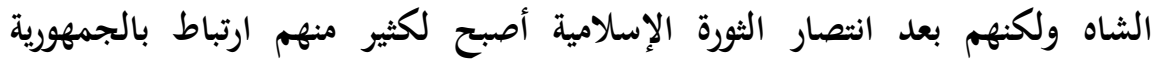
الإسلامية بإيران وكذلك سوريا(99). المبحث الثالث: اشكالية النظام السياسي في لبنان

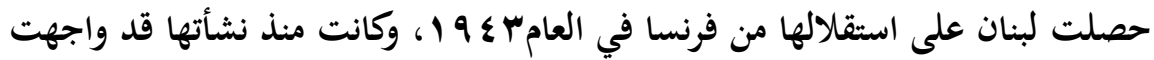
حالة عدم استقرار سياسي فضلا عن كونها دولة ضعيفة تفتقر الى مقومات الدولة القوية

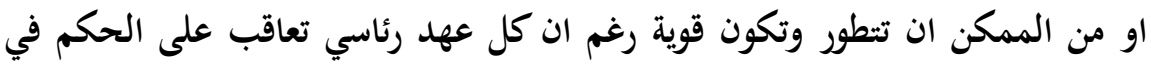
لبنان، اختار رموزا سياسية معينة لمباشرة الحكم، ان كان على مستوى رئاسة الحكومة أندان

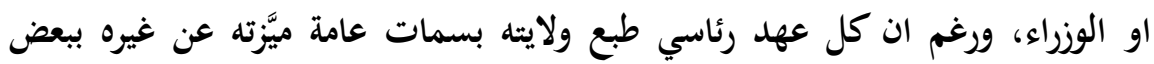

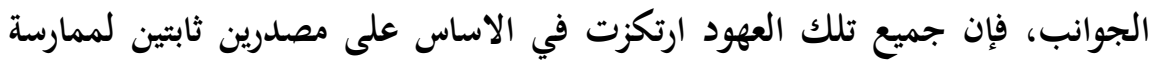




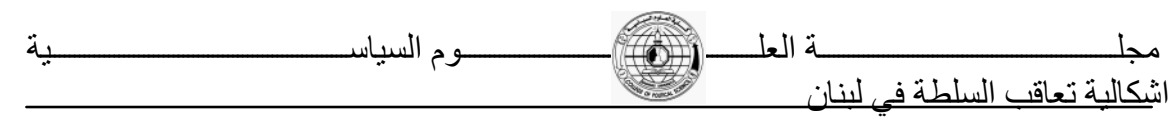

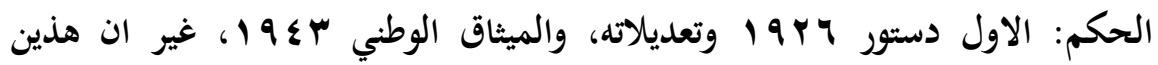

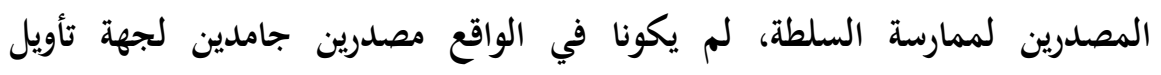

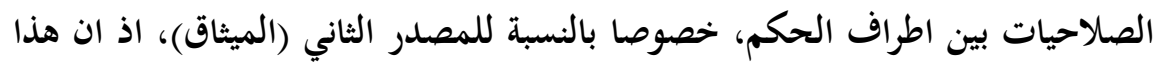

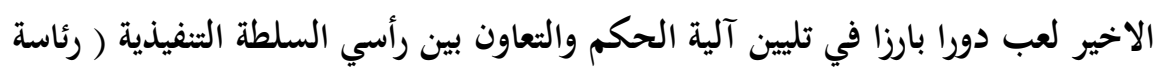

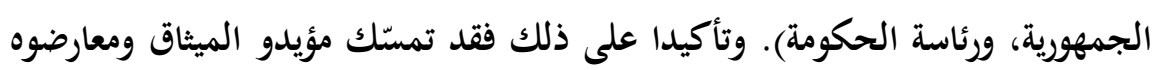

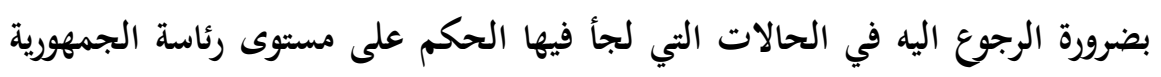

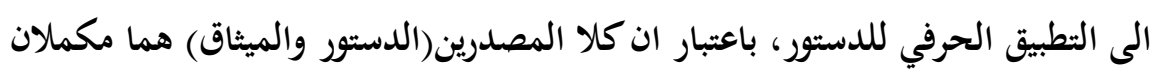

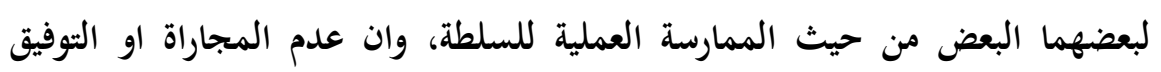

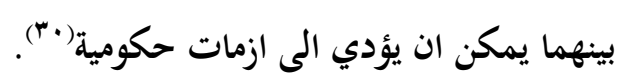

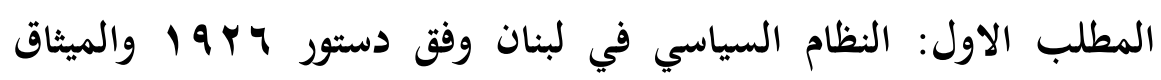

\section{الوطني لعام بـ 19}

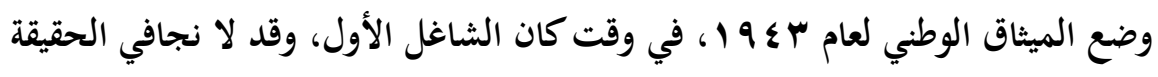

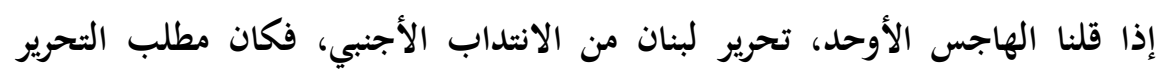

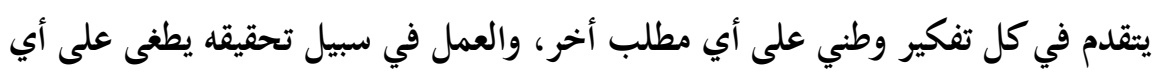

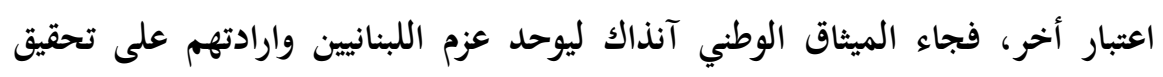

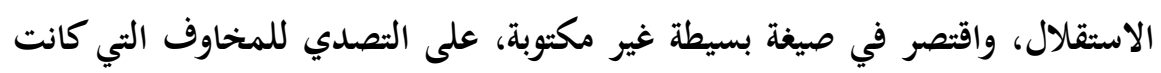

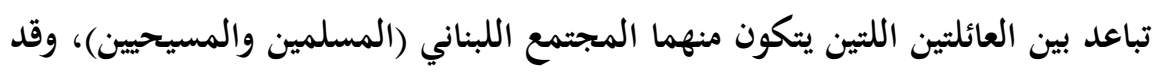

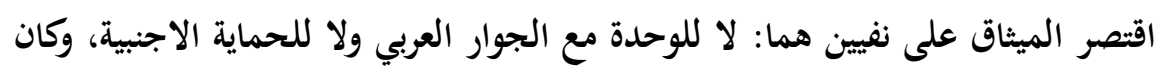

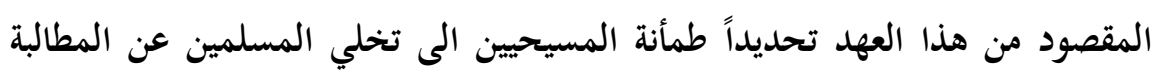

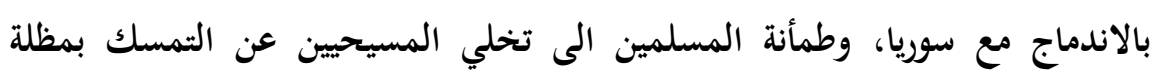

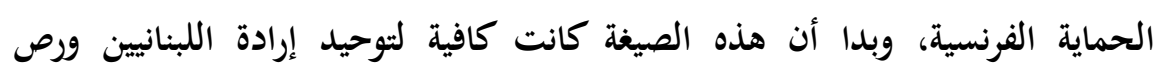
صفوفهم على مطلب الاستقلال. وفيما يتعلق بالنظام السياسي في لبنان فيمكن التطرق إليه ولو بشكل مختصر من خلال التهال المؤسسات الدستورية التي تمارس الحكومة مهامها من خلالها. 


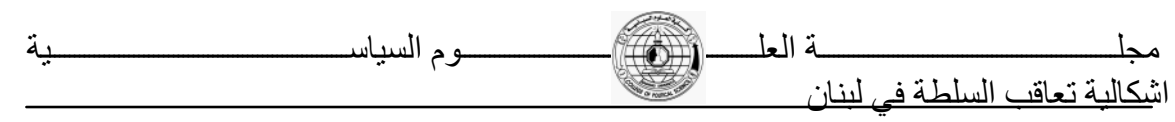

أولاً: السلطة التشريعية، السلطة التشريعية في لبنان تتولاها هيئة واحدة هي مجلس

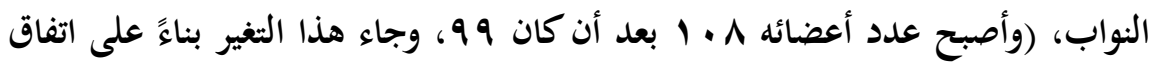

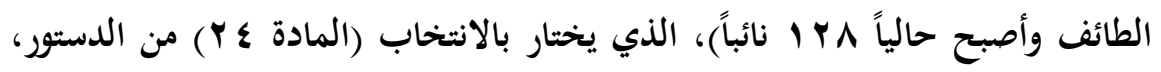

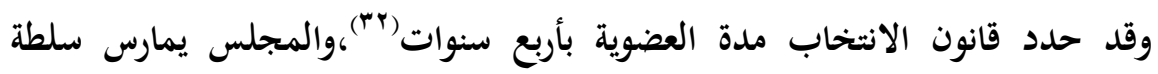

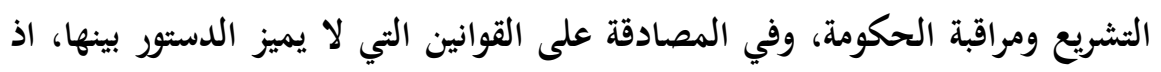

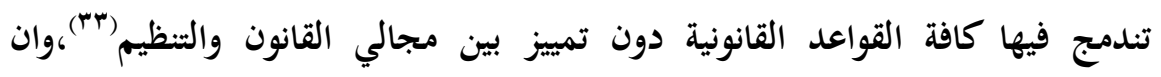

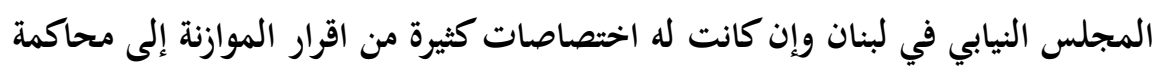

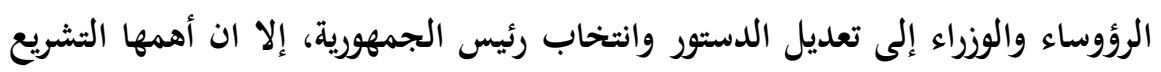

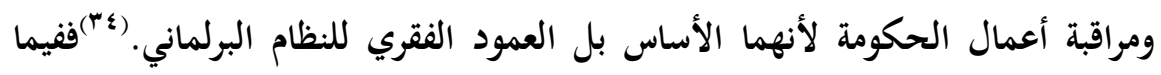

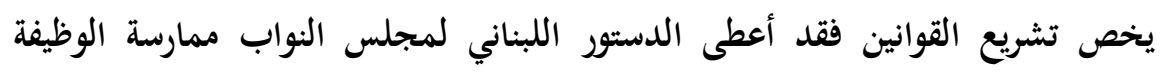

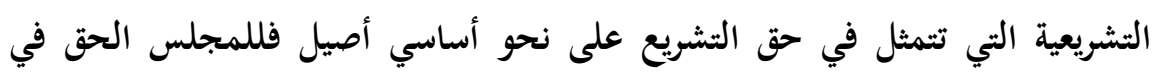

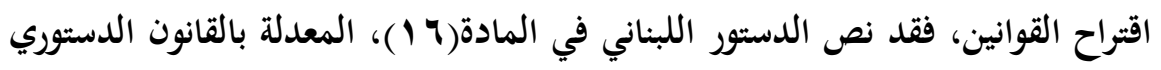

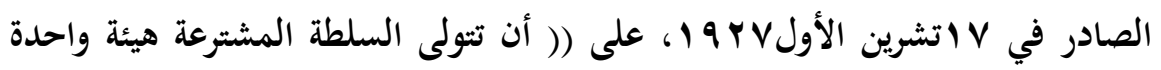

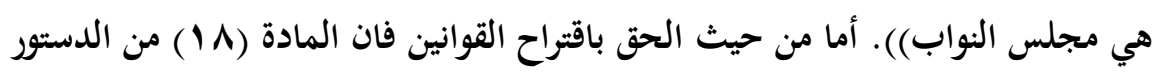

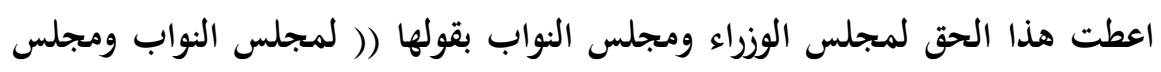

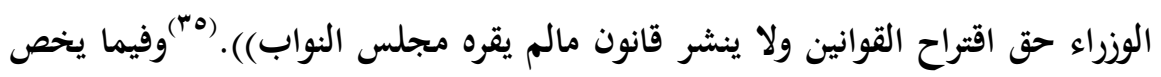

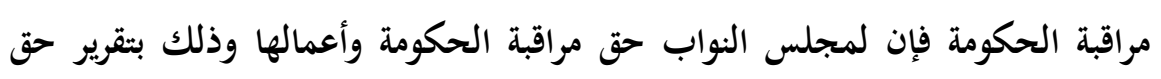

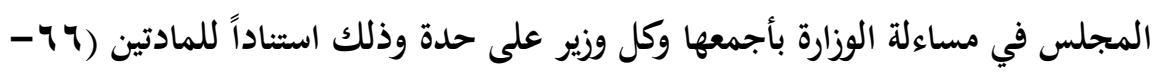

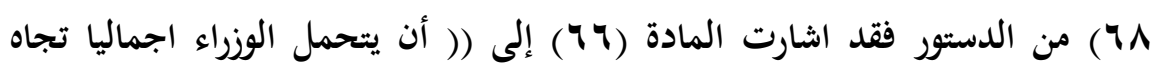

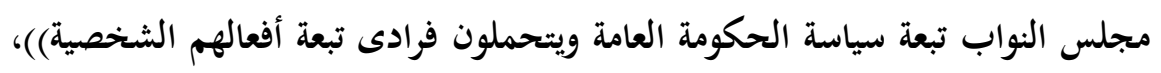

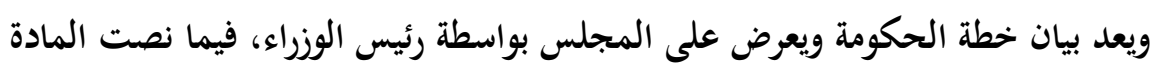

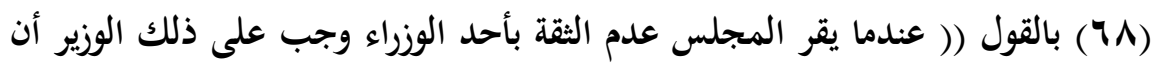

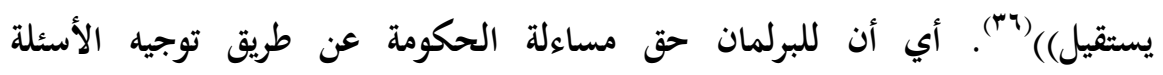

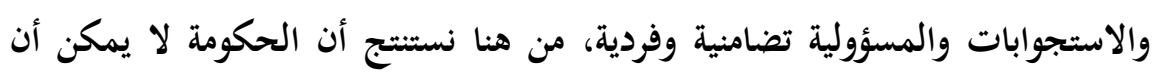




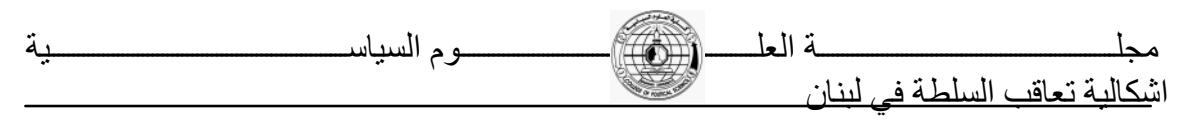

تبقى في الحكم إلا إذا حصلت على ثقة مجلس النواب، لإنها ضرورة دستورية لاستمرار

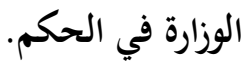

ثانياً: السلطة التنفيذية، تتكون السلطة التنفيذية في لبنان من رئيس الجمهورية والوزارة. اولاً: رئيس الجمهورية: لقد ورث رئيس جمهورية لبنان بعد الاستقلال العامجاء 19

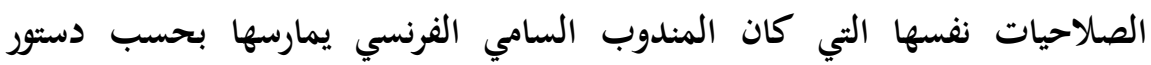

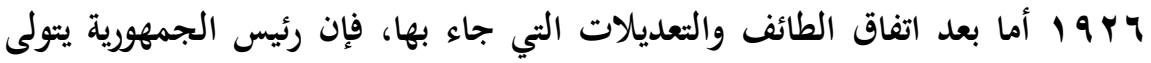
فقط سلطة رعائية، إذ جاء في المادة 9 \ من الدستور أن "رئيس الجمهورية هو رئيس

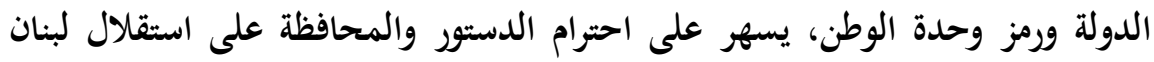

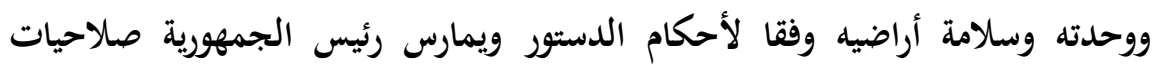

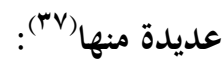
ا - يرأس مجلس الوزراء عندما يشاء دون أن يشارك في التصويت، ويرأس المجلس

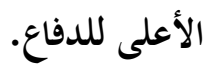

ب-بيتولى المفاوضة في عقد المعاهدات الدولية وإبرامها بالاتفاق مع رئيس الحكومة. ع-يسمي رئيس الجمهورية رئيس الحكومة المكلف بالتشاور مع رئيس مجلس النواب. ه- يصدر مرسوم تسمية رئيس مجلس الوزراء منفردا. צ- يصدر بالاتفاق مع رئيس مجلس الوزراء مرسوم تشكيل الحكومة ومراسيم قبول استقالة الوزراء أو إقالتهم.

- يصدر منفردا المراسيم بقبول استقالة الحكومة واعتبارها مستقيلة. ^-يحيل مشاريع القوانين التي ترفع إليه من مجلس الوزراء إلى مجلس النواب.

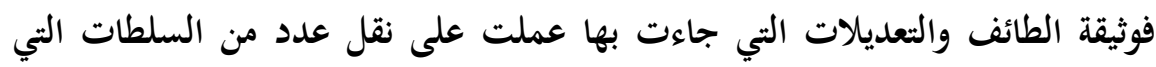
كان رئيس الجمهورية من وطابها، اذ كرس اتفاق الطائف استقلالية السلطة التنفيذية

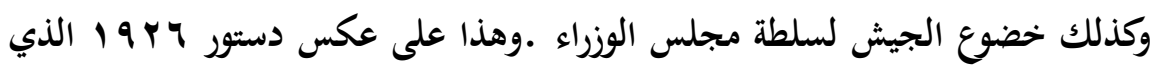
أكد في المادة V منه على أن (السلطة التنفيذية ترجع إلى رئيس الجمهورية الذي 


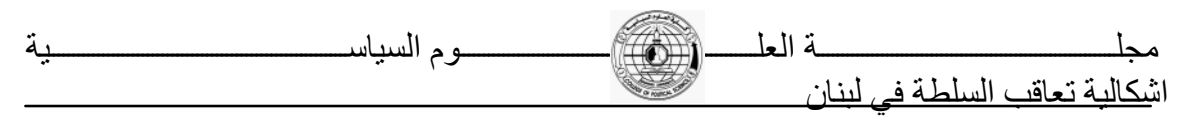

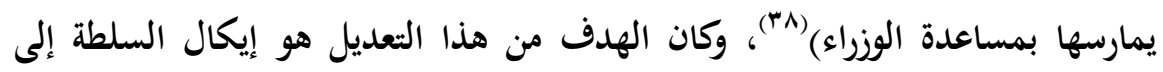

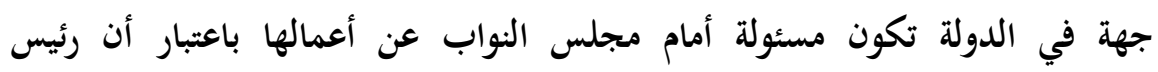

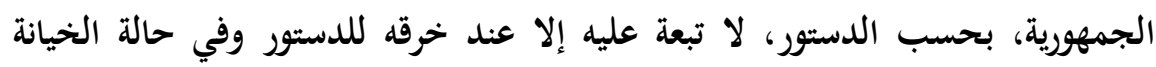

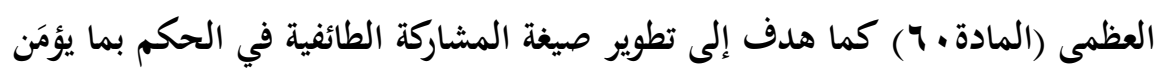

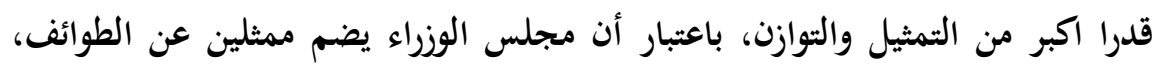

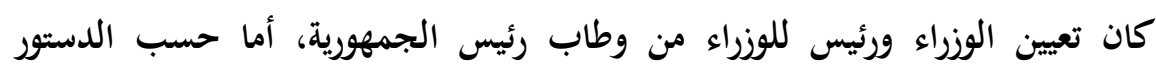

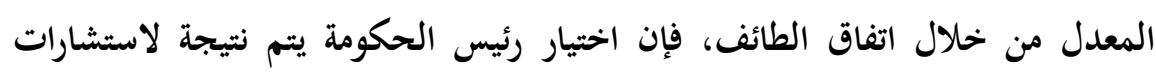

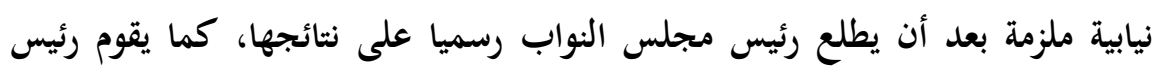

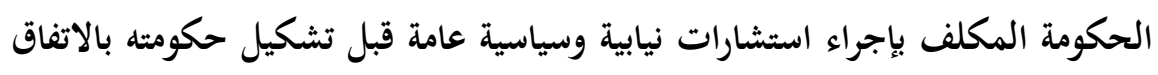

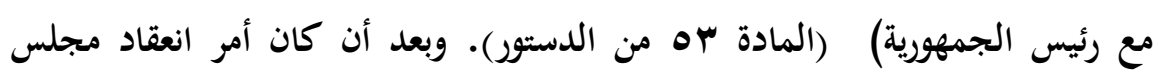

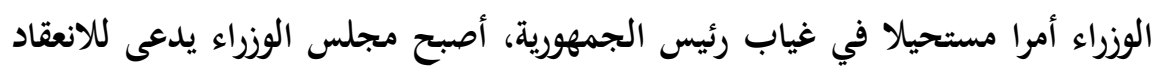

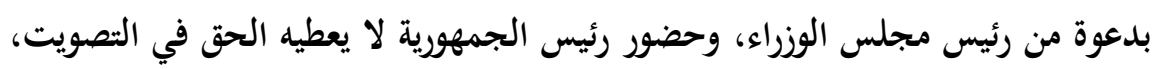

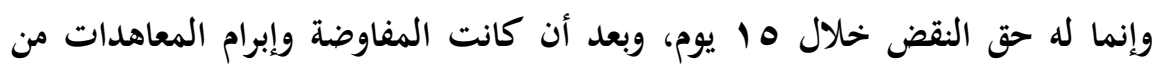

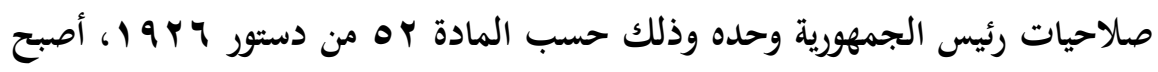

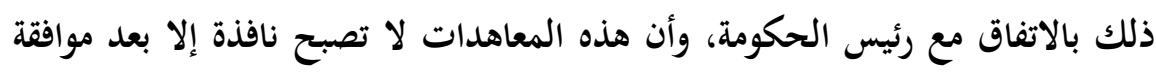

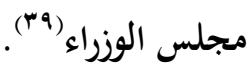

ثانياً: مجلس الوزراء: يتولى مجلس الوزراء-حسب الدستور المعدل من خلال اتفاق المال الطائف -السلطة الإجرائية، وهذا ما عبرت عنه المادة (IV): تناط السلطة الإجرائية بمجلس الوزراء ـ وهو يتولاها على وفق احكام هذا الدستور.

$$
\text { ومن الصلاحيات التي يمارسها مجلس الوزراء: }
$$

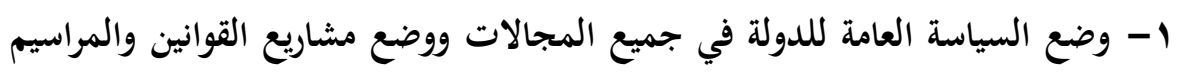

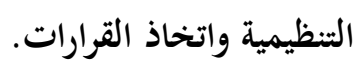




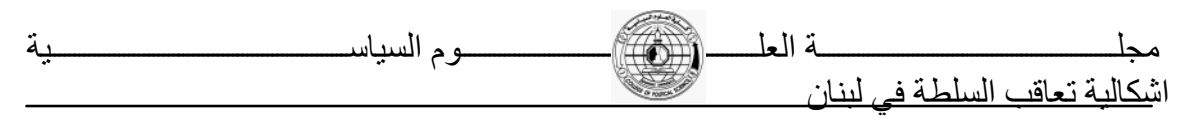

r- السهر على تنفيذ القوانين والإشراف على أعمال كل أجهزة الدولة من إدارات

$$
\text { ومؤسسات مدنية وعسكرية. }
$$

ب- ب- تعيين موظفي الدولة وصرفهم وقبول استقالتهم على وفق القانون.

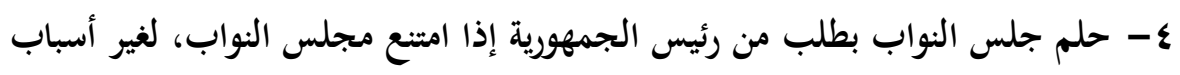

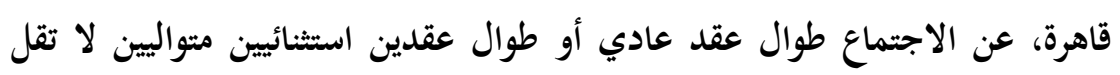

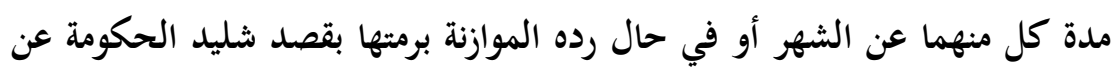

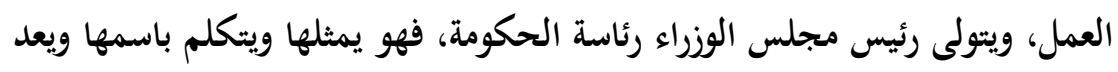

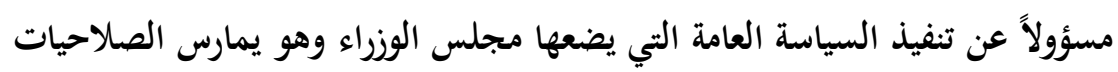

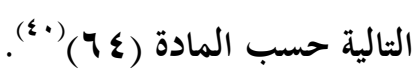

ه- يرأس مجلس الوزراء، ويجري الاستشارات لتشكيل الحكومة ويوقع مع رئيس الجمهورية مرسوم تشكيلها.

צ- يطرح سياسة الحكومة أمام البرلمان، ويوقع مع رئيس الجمهورية جميع المراسيم

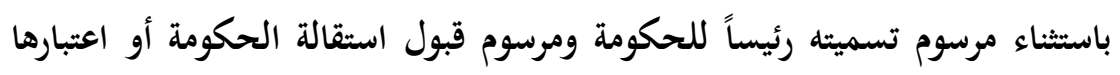

$$
\text { مستقيلة. }
$$

المطلب الثاني: تناقضات النظام السياسي في لبنان

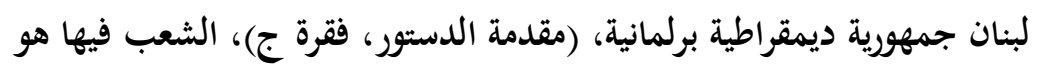

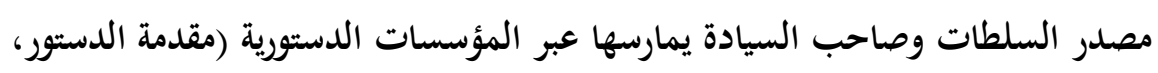

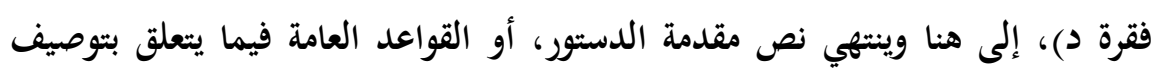

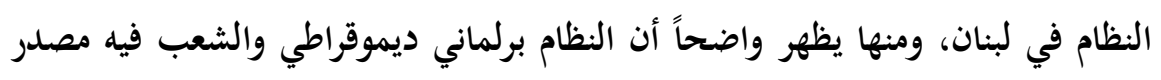

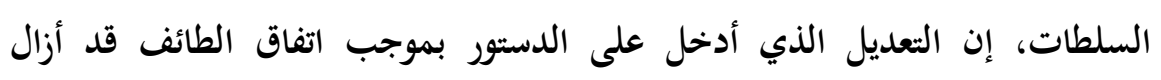

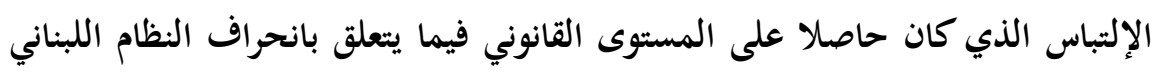

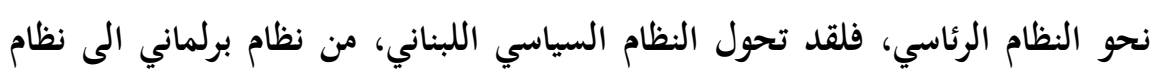

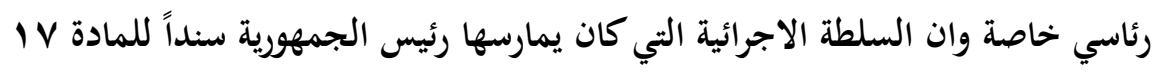




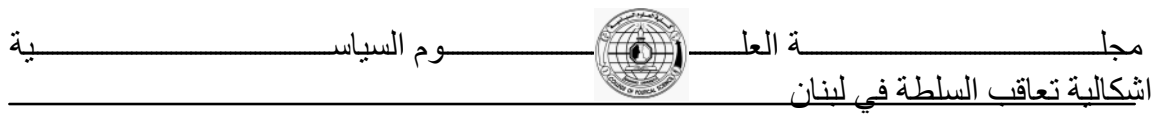

من الدستور بمعاونة الوزراء، تحولت بعد تعديل هذه المادة الى مجلس الوزراء مجتمعاً

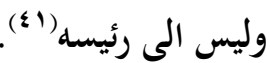

وقد أجمع رجال القانون والسياسة على أنّ تعديلات الطائف غيّرت طبيعة

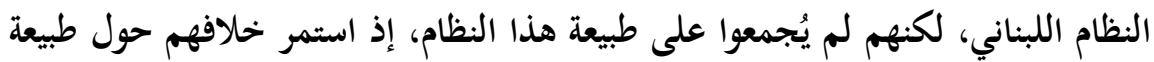

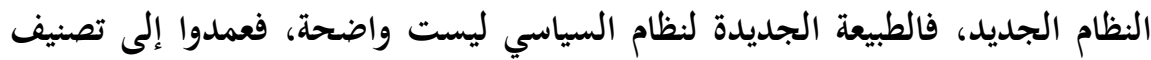

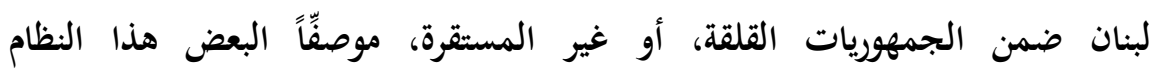

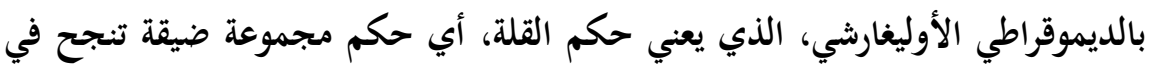

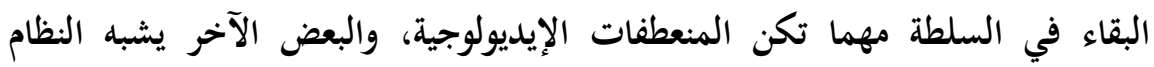

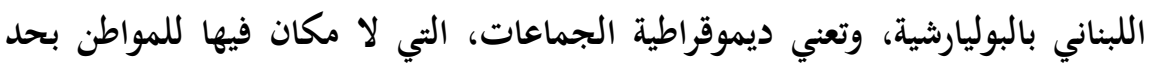
ذاته، وهذه الجماعات هي جماعات طائفية-إقطاعية- مافيوية في لبنان بطبيعة الحال،

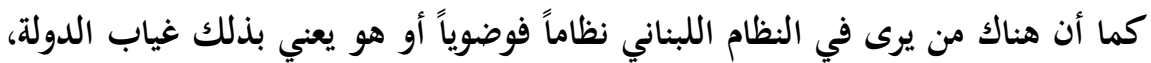

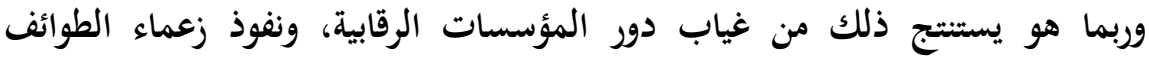

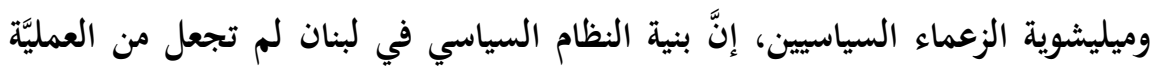

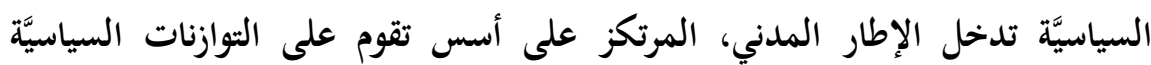

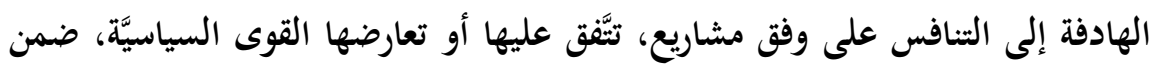

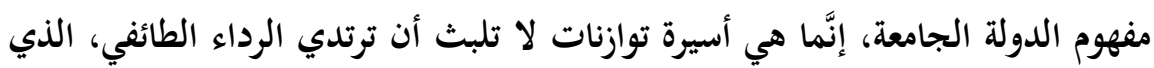

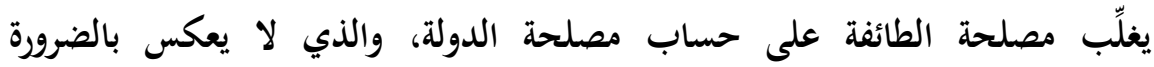
الطروحات السياسيَّة التي تربّح طرحاً على آخر وفق معايير الديمقراطيَّة التنافسيَّة، إنَّما

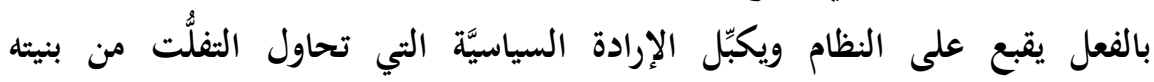

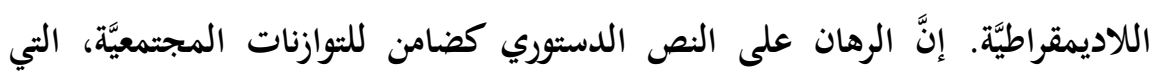

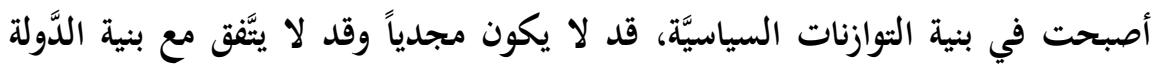

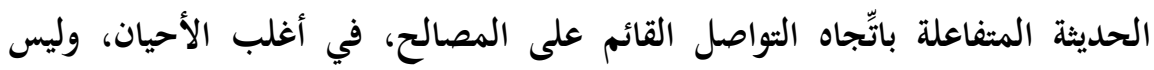

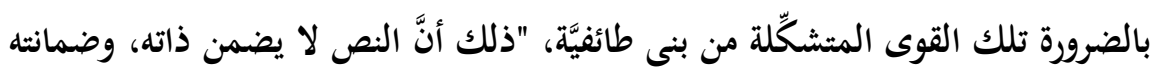

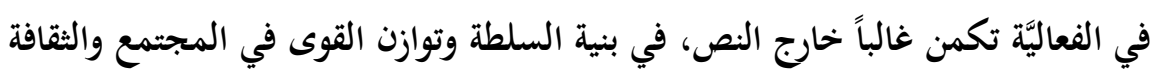




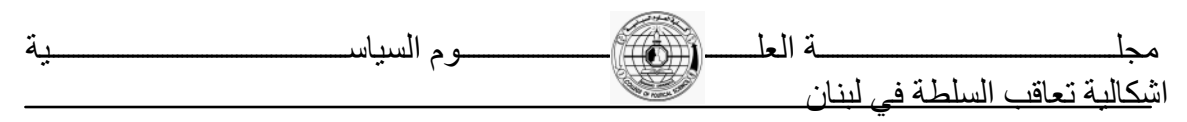

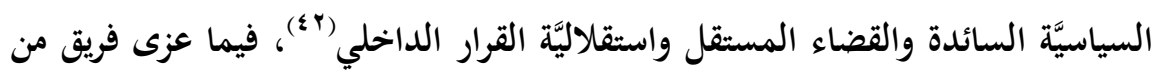

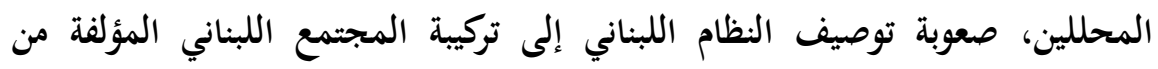

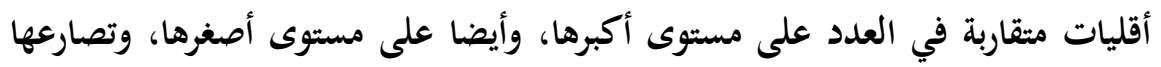

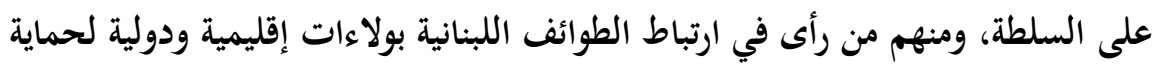

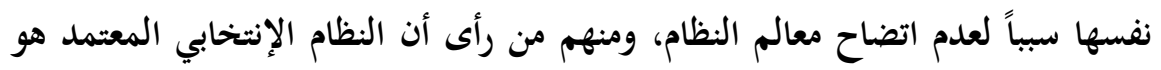

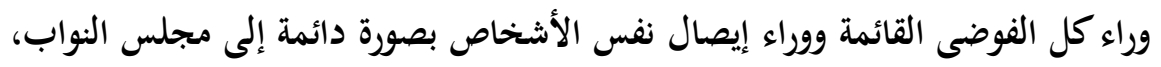

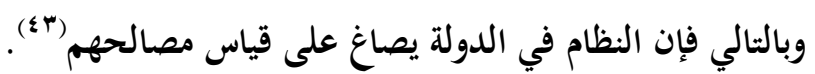

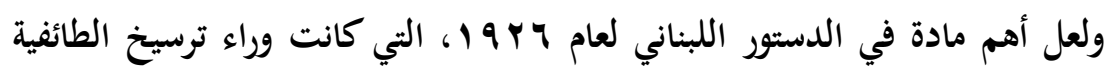

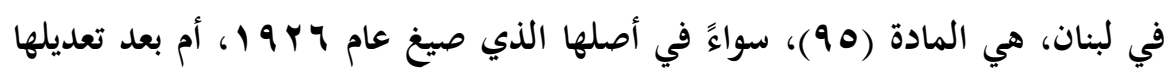

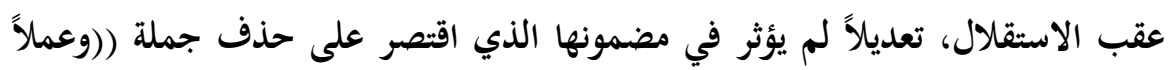

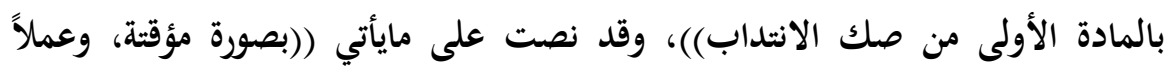

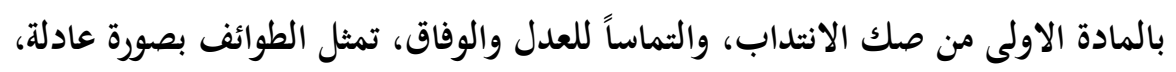

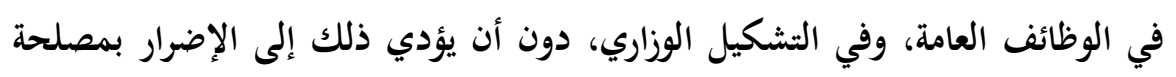

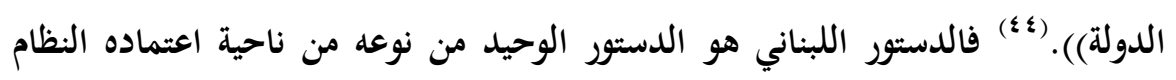

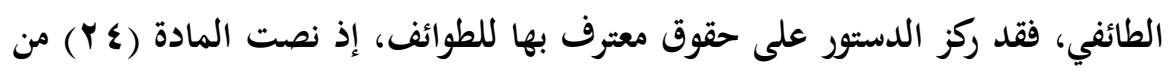

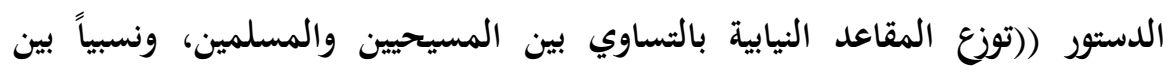

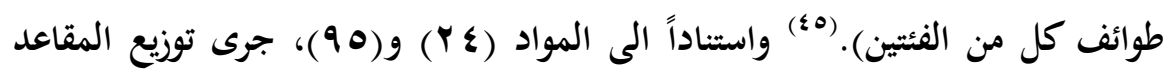

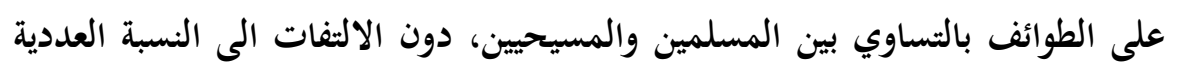

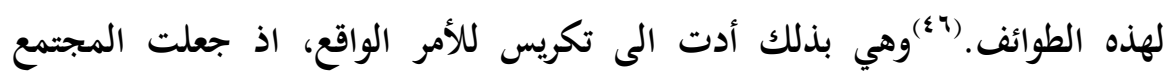

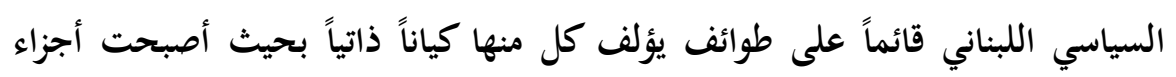

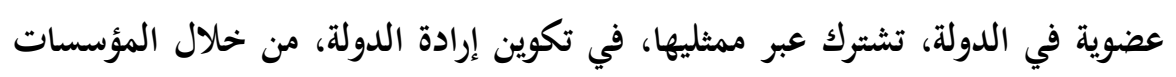

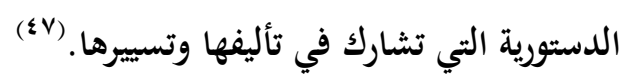

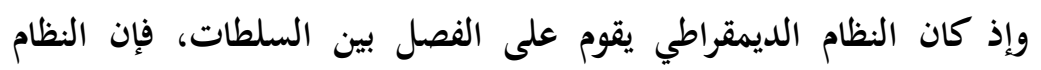

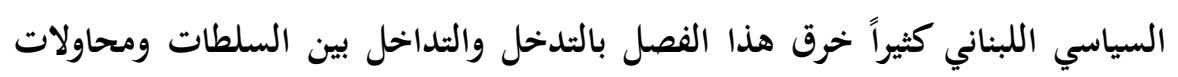




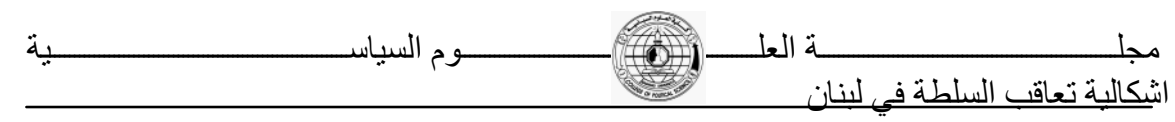

الاستئثار والهيمنة على القوى المسيطرة على مؤثرات القضاء وكذلك على البرلمان،

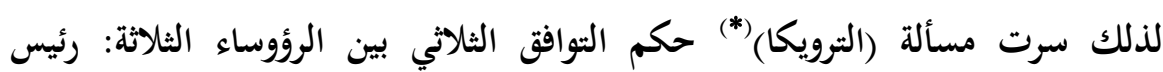

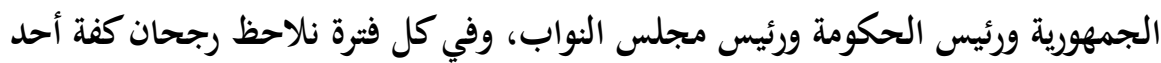
الرؤساء الثلاثة على باقي المؤسسات، في حين خضعت السلطة القضائية لهيمنة رجال السياسة واستخدام القضاء في ميدان التنافس والصراع السياسي، وبذلك فقد التد النظام الديمقراطي أحد أهم ركائزه وهو الفصل بين السلطات لتقوم كل منهما بدورها، فالسلطة التنفيذية المتمثلة بالحكومة تدخلت في العمل التشريعي والبرلماني وأخضعت القضاء لسلطنها، فيما يمارس القضاء العمل السياسي عبر الخضوع لرغبات السلطة التنفيذية،

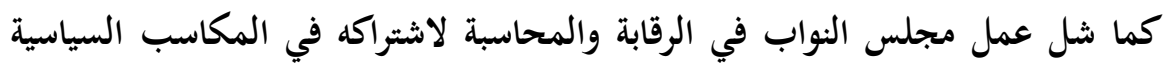
للسلطة التنفيذية والقضائية. (^؛)

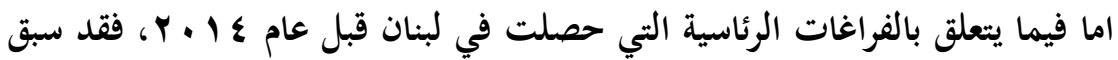

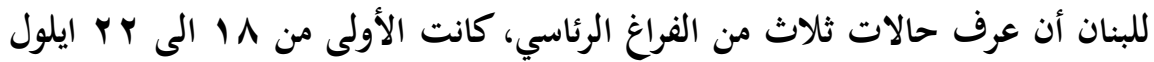
190r بعد عزل الرئيس بشارة الخوري، تشكلت حكومة عسكرية برئاسة فؤاد شهاب

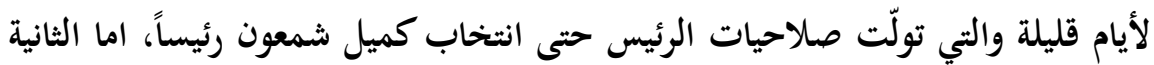

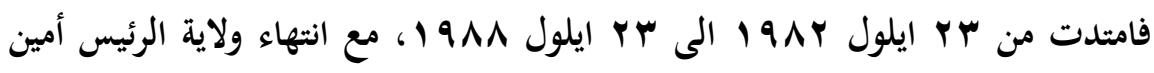

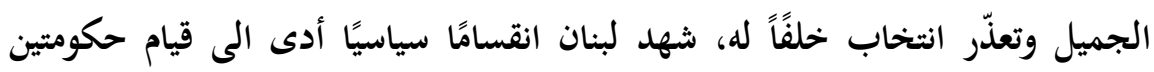
الأولى برئاسة العماد ميشال عون والثانية برئاسة الدكتور سليم الحص واللتين تنازعتا

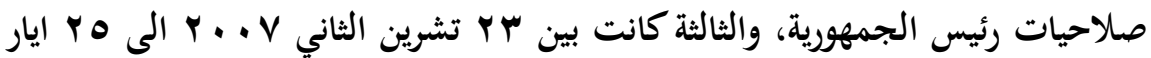

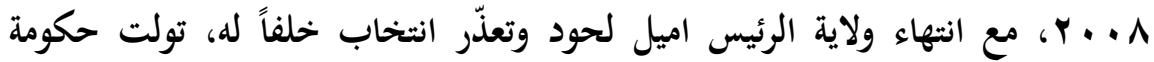
الرئيس فؤاد السنيورة صلاحيات رئس الجمهورية حتى انتخاب العماد ميشال

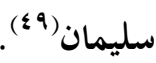

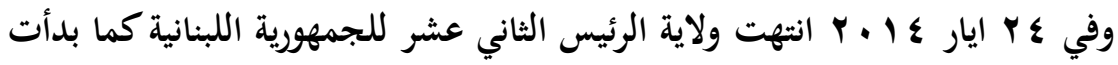

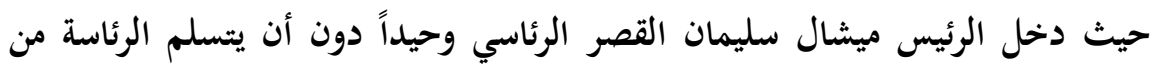

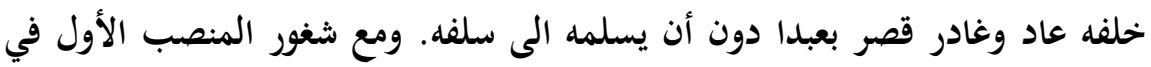




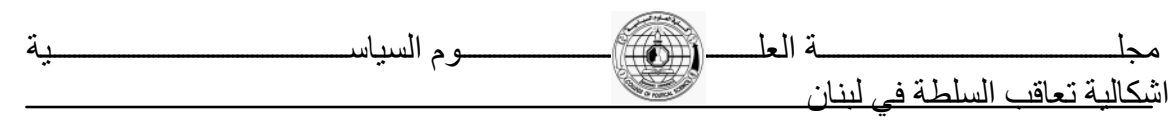

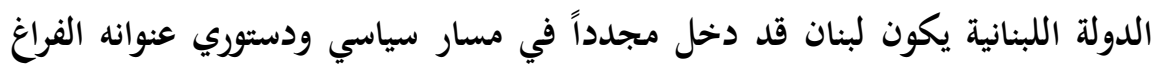

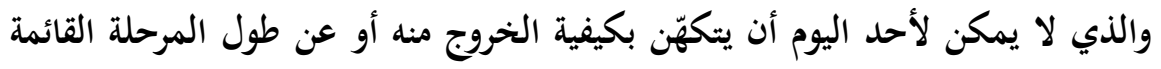

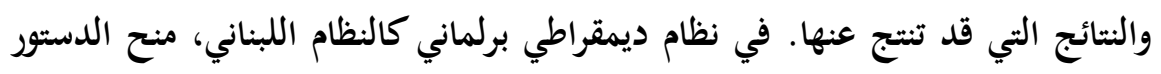

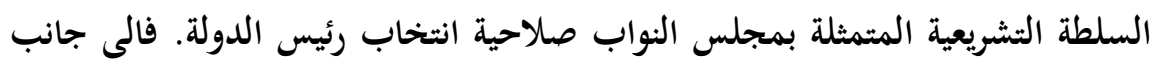

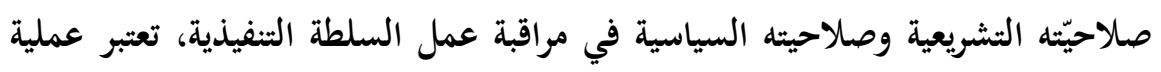

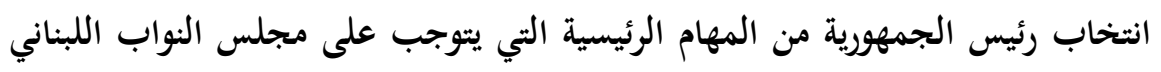

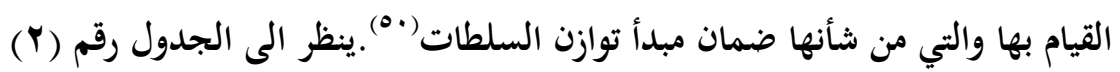

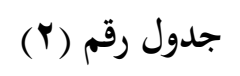

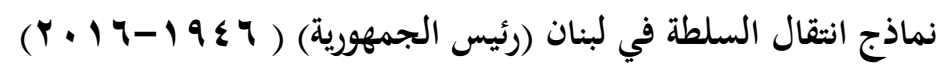

\begin{tabular}{|c|c|c|c|c|}
\hline ملاحظات & نموذج انقلقال & متى وكيف ترك السلطة & متى وكيف تولى & الحاكم \\
\hline تم تمديد رئاسته & انتخابي- سلمي & ra 190 العزل بالقوة & r r 19 1 بالانتخاب & 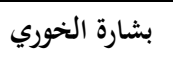 \\
\hline \multirow{6}{*}{ رفض تسليم السلطة بعد } & انتخابي- سلمي & 1901 1901 العزل بالقوة & بو1904 بالانتخاب & كميل شعون \\
\hline & تدخل عسكري عنيف & צ \9 19 انتهاء مدته القانونية & 1901 بالقوة & فؤاد شهاب \\
\hline & انتخابي- سلمي & • Y ا انتهاء مدته القانونية & ـ צ 19 بالانتخاب & شارل حلو \\
\hline & انتخابي سلمي & 79V7 انتهاء مدته القانونية & 19v. 19 بالانتخاب & سليمان \\
\hline & & & & فرنجية \\
\hline & انتخابي- سلمي & 19AY انتهاء مدته القانونية & 49V 19v بالانتخاب & الياس سركيس \\
\hline \multirow[t]{2}{*}{ اغتيل قبل توليه السلطة } & انتخابي-غير سلمي & كا9 19 الاغتيال & raA19 بالانتخاب & بشير الجميل \\
\hline & انتخابي- سلمي & 19 19 انتهاء مدته القانونية & raA1 19 بالانتخاب & امين الجميل \\
\hline اغتيل بعدة توليه السلطة & انتخابي- سلمي & (919 1919 الاغتيال & 19/9 19 بالانتخاب & رينيه معوض - لموض \\
\hline تم التمديد له نصف فترة & انتخابي- سلمي & 19 191 انتهاء مدته القانونية & 919 19 بالانتخاب & الياس الهراوي \\
\hline تم التمديد له نصف فترة & انتخابى - سلمى & V . . F انتهاء مدته القانونية & 1991 19 بالانتخاب & إميل لحود \\
\hline
\end{tabular}




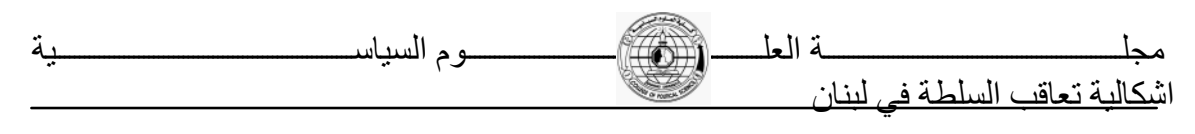

\begin{tabular}{|l|c|c|c|c|}
\hline & & & & \\
\hline & ميشال \\
& & ميمان & \\
\hline
\end{tabular}

المصدر: صلاح سالم زرنوقة، أنماط انتقال السلطة في الوطن العربي: منذ الاستقلال وحتى بداية ربيع الثورات العربية،موكز

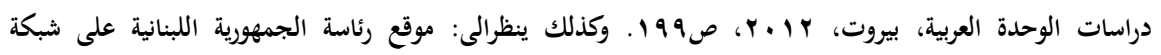
WWw.presidency.gov.lb/:المعلومات الدولية(الانترنت) نستنتج من خلال تحليل الجدول أعلاه ان مسألة التعاقب على السلطة في لبنان لم

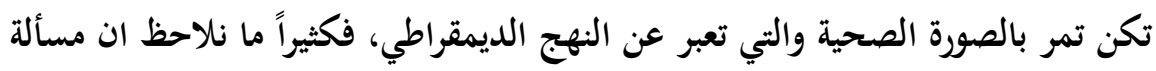
انتقال السلطة تمر بمنعطف حرج وخطير من خلال رفض تسليم السلطة، او اغنيال

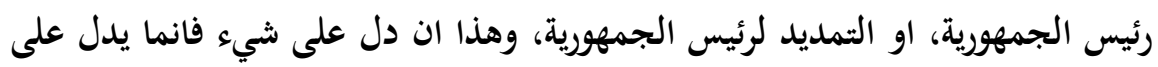
عدم الاستقرار السياسي وبالنتيجة والتي أثرت بشكل كبير على مسألة انتقال السلطة. يمكن القول ان آفة لبنان فيما يتعلق بقضية انتقال السلطة ترجع في الحقيقة التئل الى أمرين:

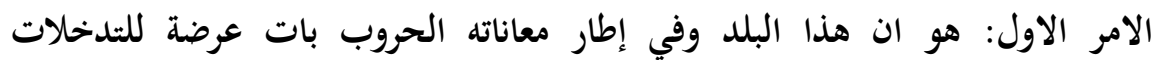

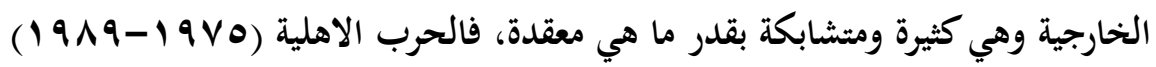
لم تكن حرباً في لبنان فقط، بل كانت حرباً على لبنان، اي من خلالاله، ومن ثمّ كانت حالات الخروج عن الخط الديمقراطي مرتبطة بعوامل خحارجية أو ناجمة عنها، على سبن سبيل

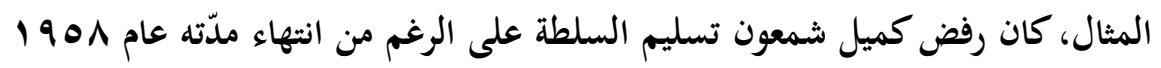

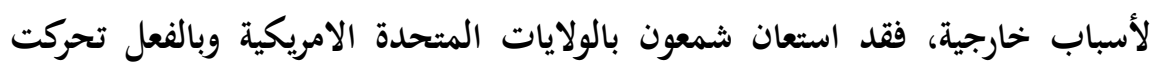

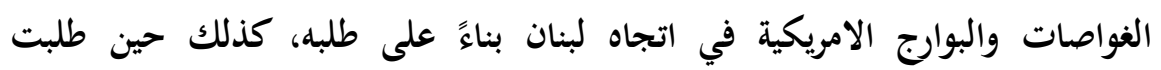
مجموعة من ضباط الجيش المسلمين الذين قاموا بمحاولة انقلاب تم اجهاضها في لئي

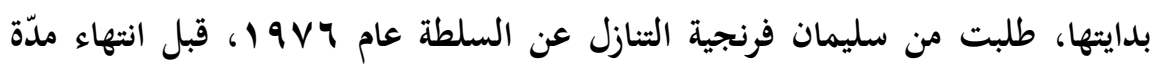

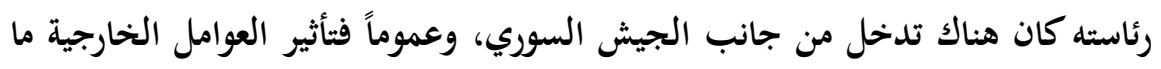

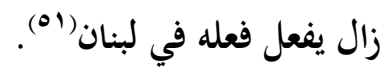
الامر الثاني: هو ان لبنان عانى ويعاني وجود أزمة نظام بوجه عام، هذه الازمة لم تكن ناجمة عن مشكلة في انتقال السلطة وإنما هي التي انعكست على على انتقال السلطة، 


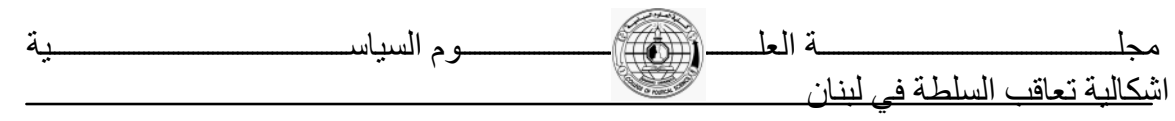

بعبارة أخرى لم تكن العلاقة بين انتقال السلطة والنظام السياسي في لبنان تفاعلية كما هي الحال في كل نظم العالم، وانما كانت علاقة من جانب واحد احتلت فيها عملية

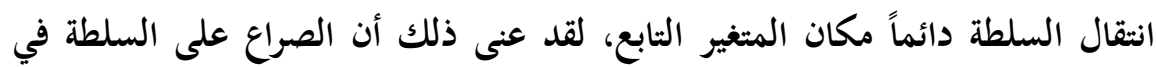

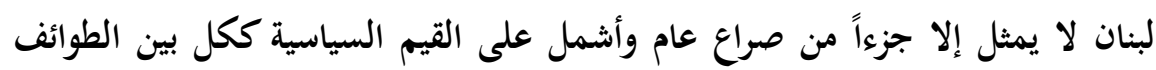

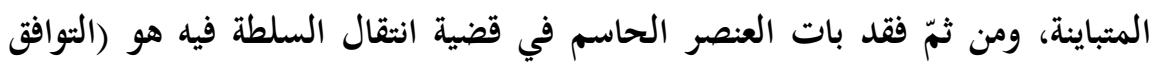

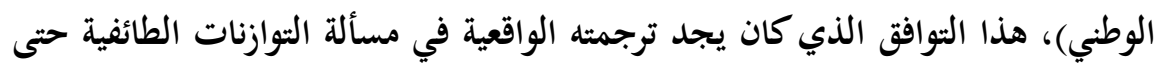
وقت قريب، ولكن لسوء الحظ فقد تعاونت الحرب الاهلية والتدخلات الخارجية والبيئة الاقليمية، تعاونت كلها على إضعاف الدولة في لبنان، ومن ثم فقد أقحمت نوعاً جديداً من التوازنات في معادلة التوافق الوطني، وهو التوازنات بين المؤسسات المدنية لهنية

$$
\text { والمؤسسات العسكرية(ه). }
$$

وهنا لابد من التطرق للانتخابات النيابية لعام \1 ـ ب، وما افرزته تلك الانتخابات، فهي

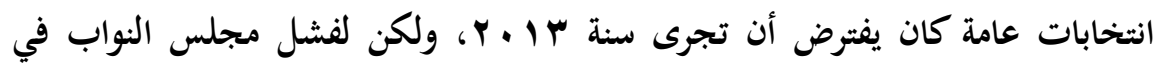

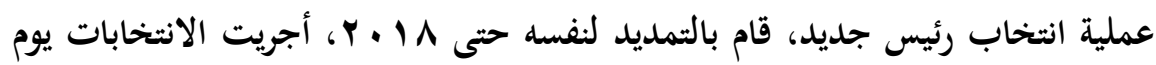

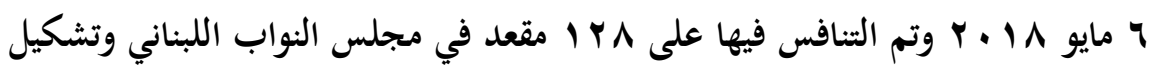

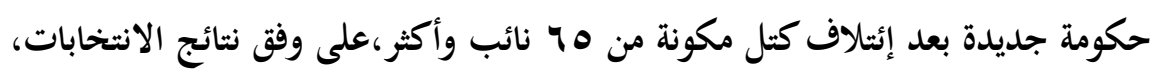
فاز حزب الله وحلفاؤه السياسيون بمقاعد أكثر مما حصلوا عليه من قبل، وتقلصت وند حصة تيار المستقبل بقيادة رئيس الوزراء سعد الحريري بنسبة الثلث، ضاعفت القوات اللبنانية، وهي حزب يميني مسيحي مناهض لحزب الله، مقاعدها من ^ 1 إلى 17 الى داخل

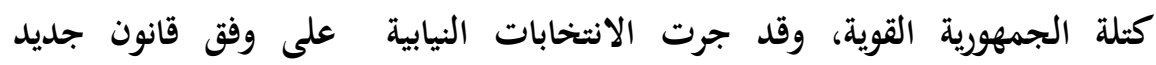

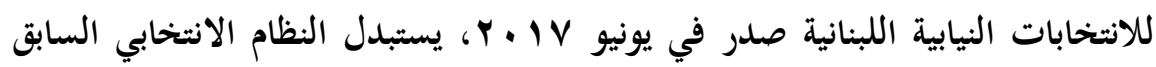

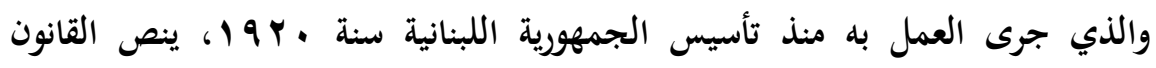

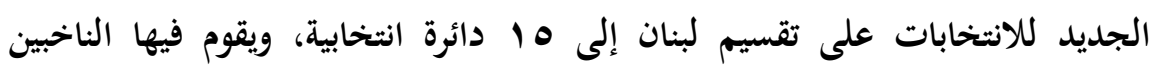

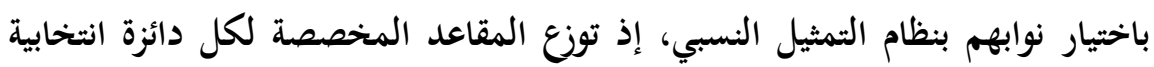

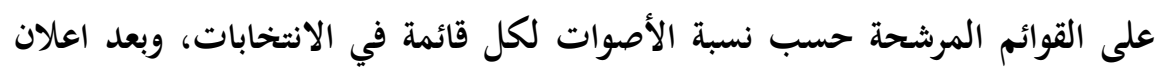




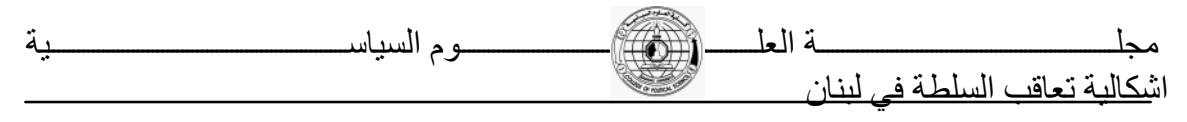

نتائج الانتخابات كلف الرئيس اللبناني العماد ميشيل عون رئيس حكومة تصريف

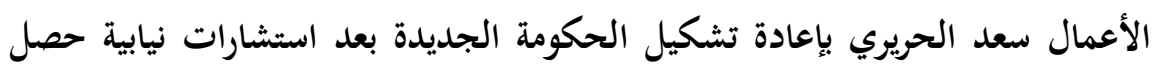

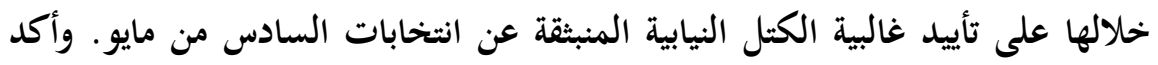

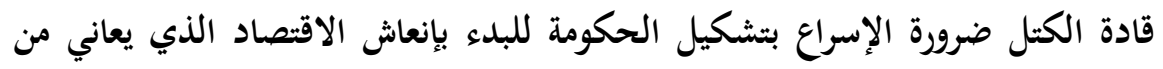

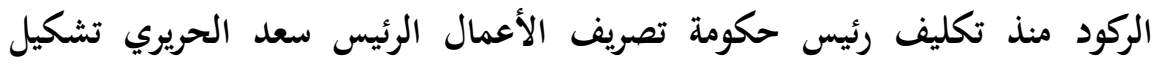

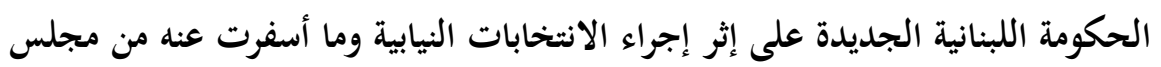

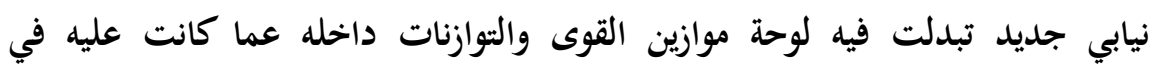

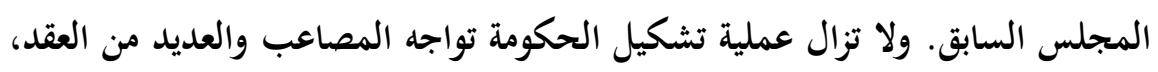

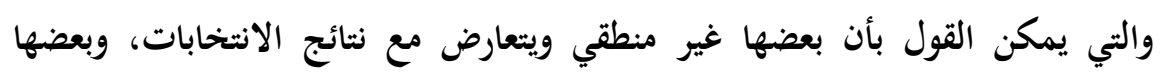

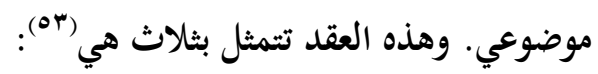

العقدة الأولى: مطالبة كتلة القوات اللبنانية بحصة وزارية تفوق حجمها النها النيابي، فهي

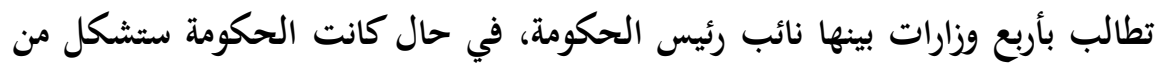

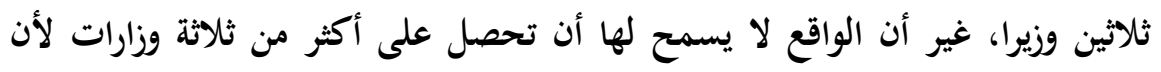

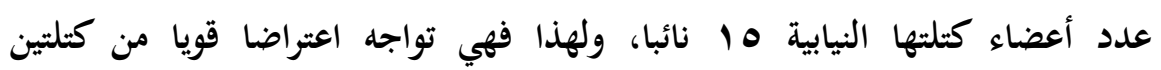

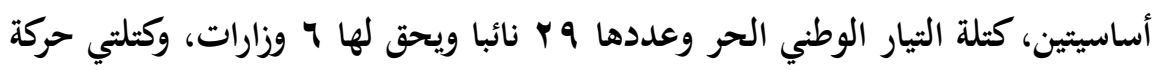

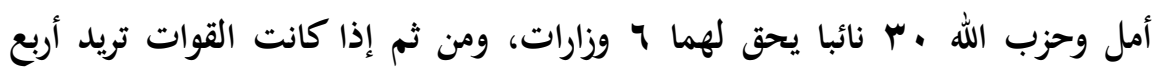

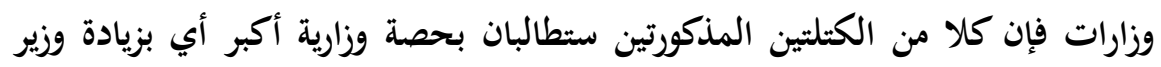

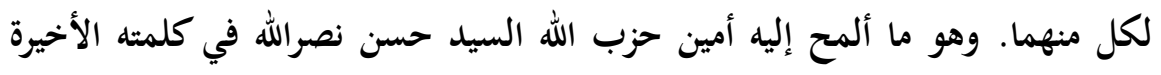

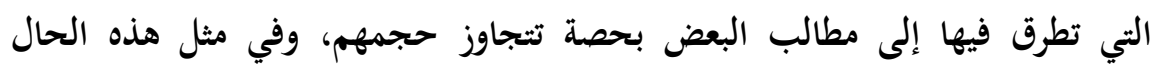

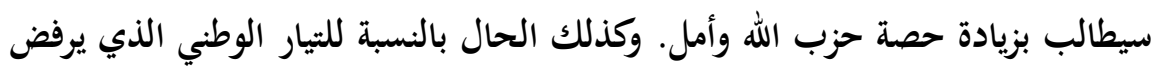
إعطاء القوات حصة أكبر من حجمها النيابي.

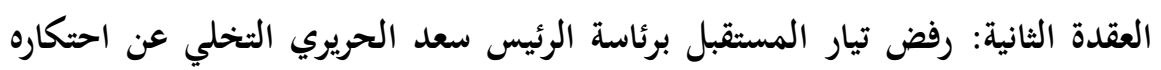

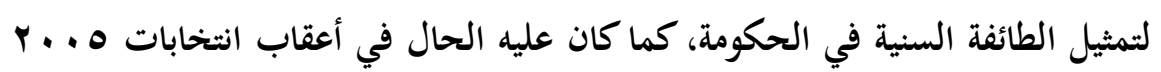

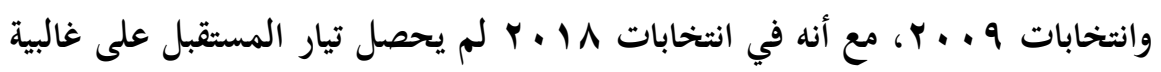




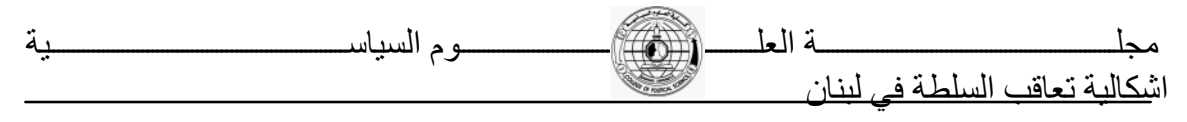

المقاعد السنية، فحسب النتائج هناك عشرة نواب سنة فازوا من خارج تيار المستقبل،

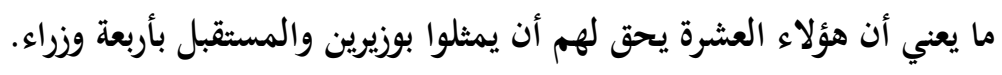

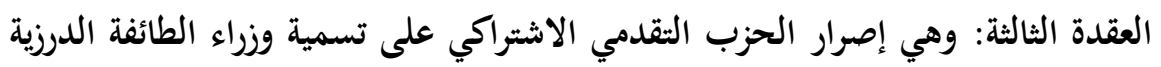

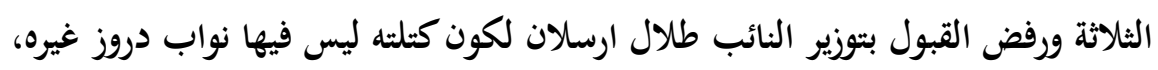
وكتلة التقدمي تضم معظم النواب الدروز.

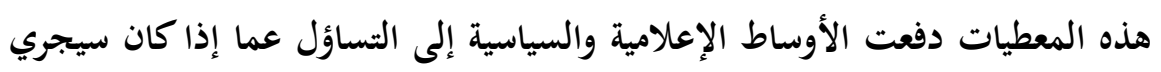
تذليل هذه العقد في فترة قريبة وتشكل الحكومة في فترة قصيرة، أم أن الأمر سيطول أكثر من ذلك؟، في هذا السياق هناك اتجاهان:

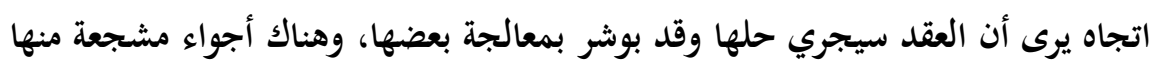

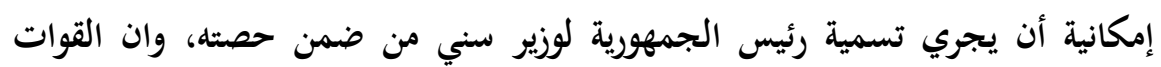

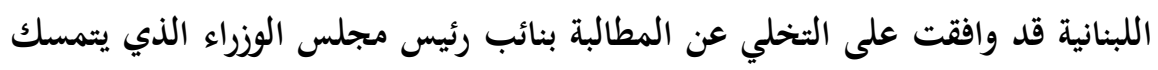

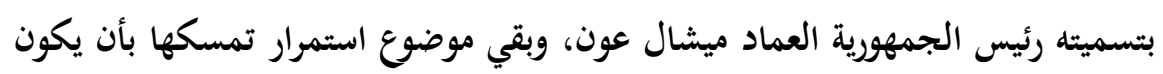

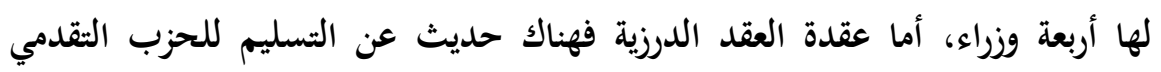

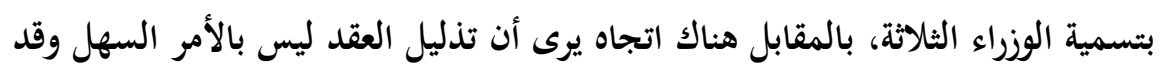

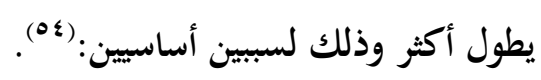

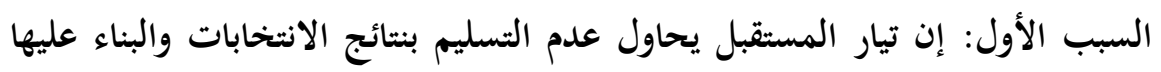
في تشكيل الحكومة، وهو يتصرف أو يريد أن يستمر في سياسة الاحتكار والإني الاستئنار

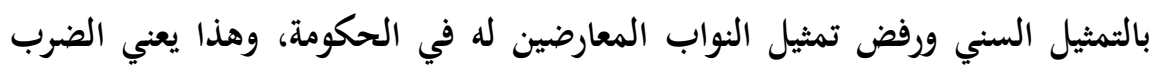

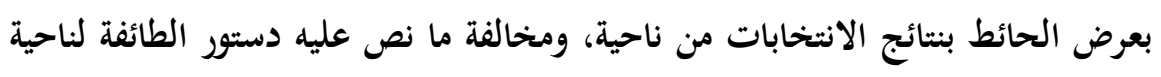

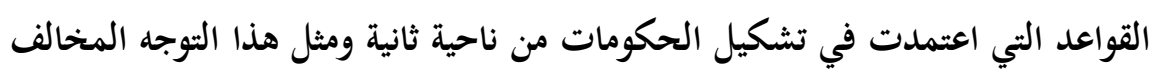

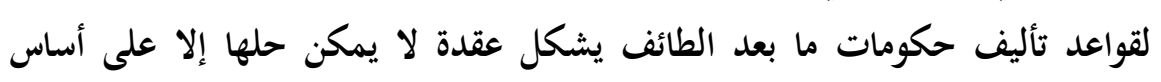

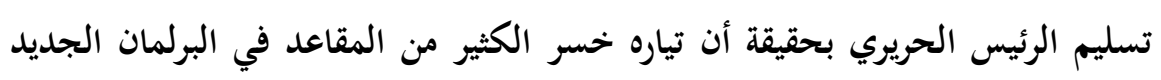

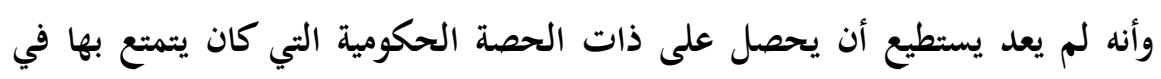




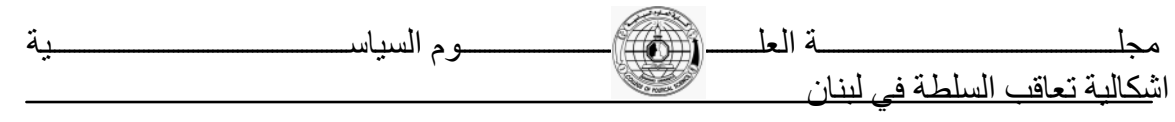

الحكومة السابقة، وإلا ما هي قيمة إجراء الانتخابات وما نتج عنها إذا لم تنعكس في إعادة تشكيل السلطة.

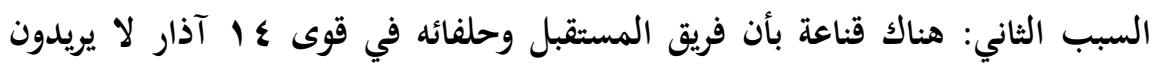

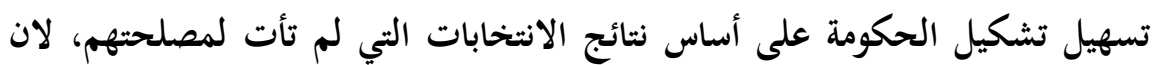

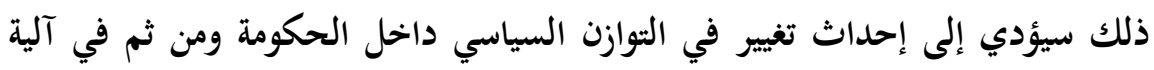
اتخاذ القرارات المرتبطة بالسياسات الداخلية والاقتصادية والمالية، والسياسات

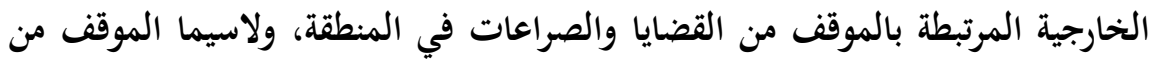

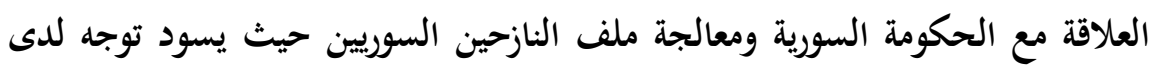

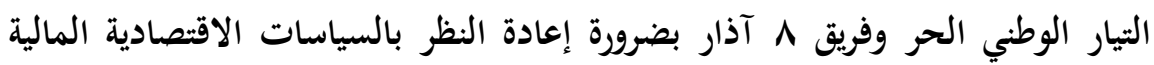

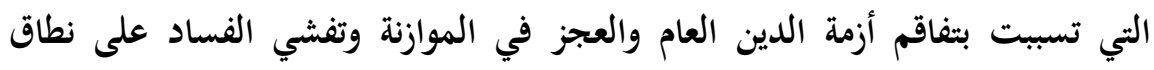

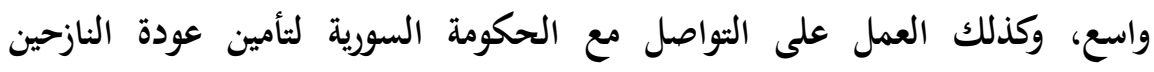

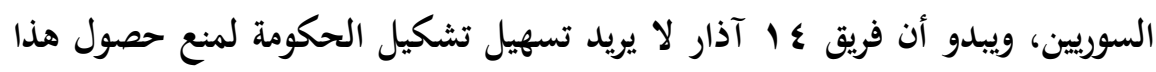

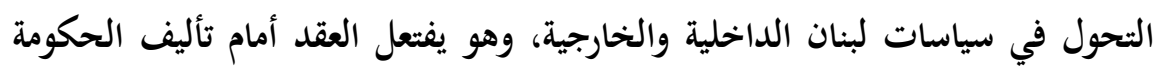

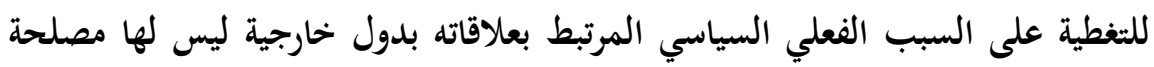

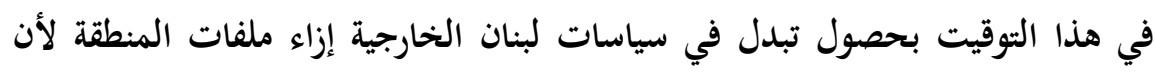
ذلك سيؤثر سلبا عليها بإضعاف موقفها.

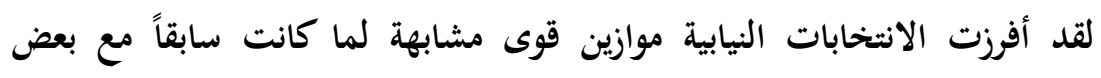

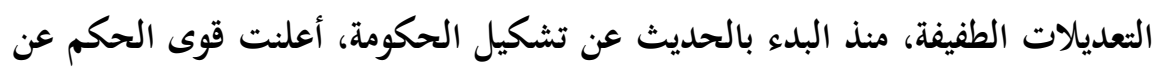

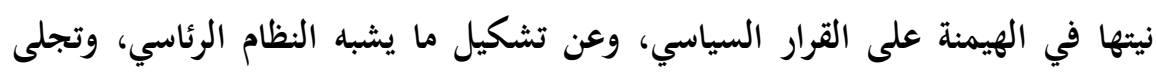

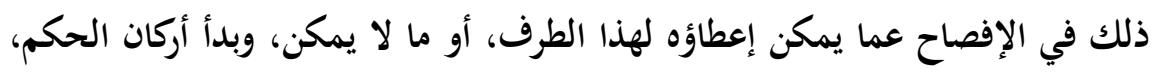

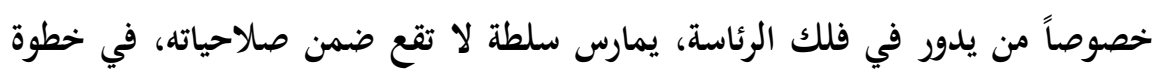

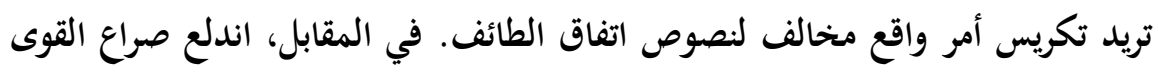

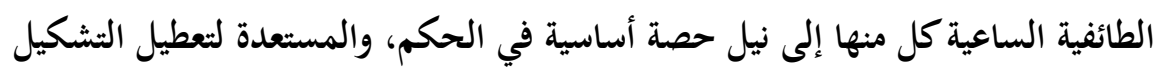
إذا لم تُلبَّ مطالبها. هكذا يقف كل طرف عند متراسه، غير مستعد للتنازل (00). 


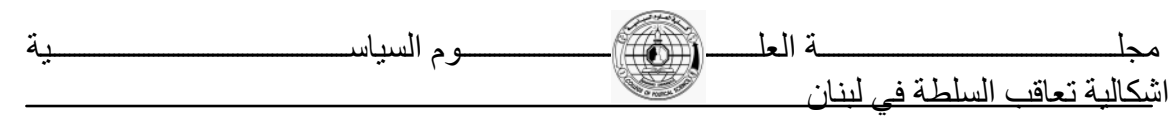

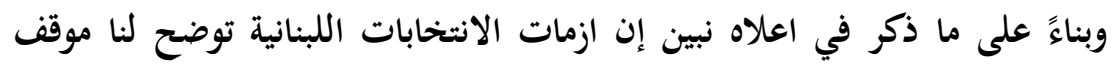

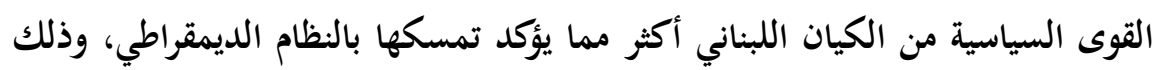

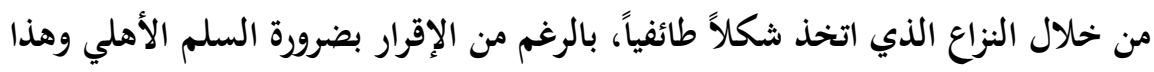

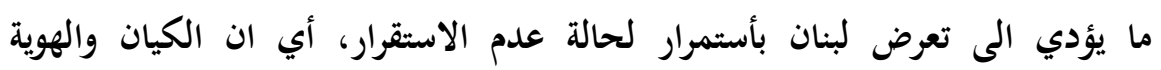
والمؤسسات كانت وما زالت مادة جدل وتفسير بين مختلف القوى اللبنانية(ه).

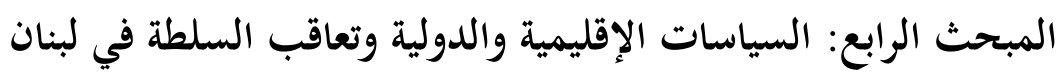

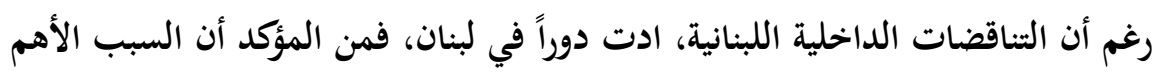

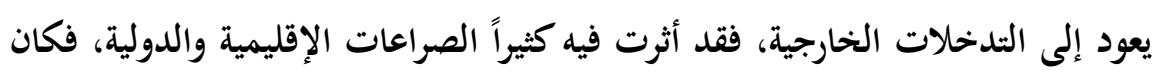

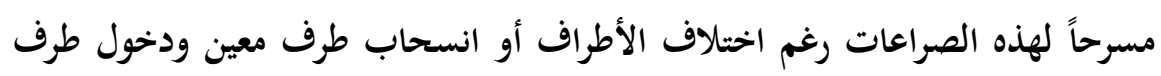

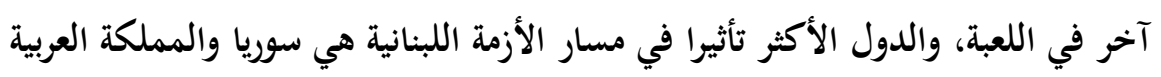

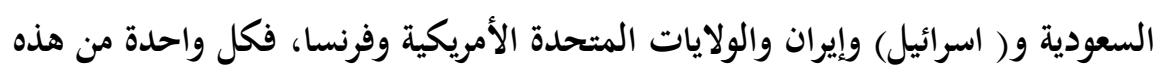

$$
\text { الدول كان لها تأثير مباشر أو غير مباشر في لبنان. }
$$

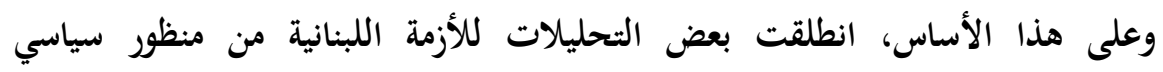

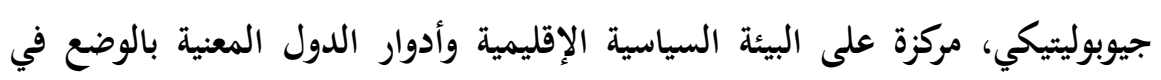

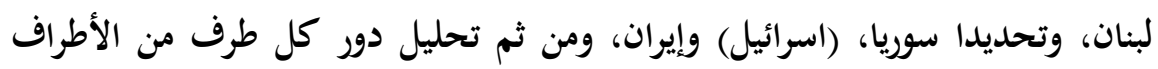

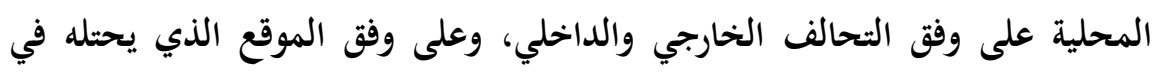

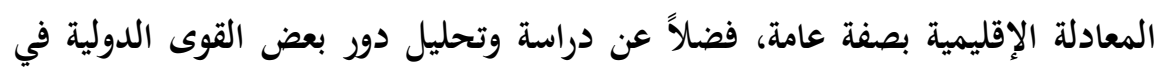

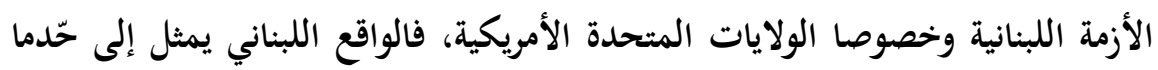

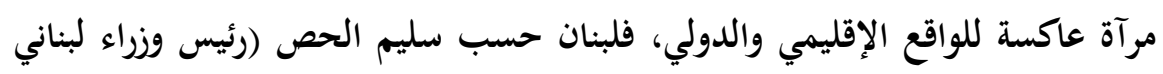

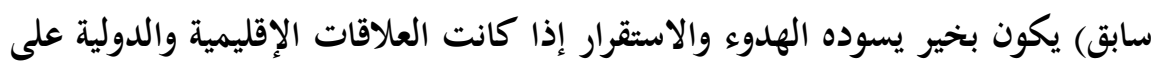

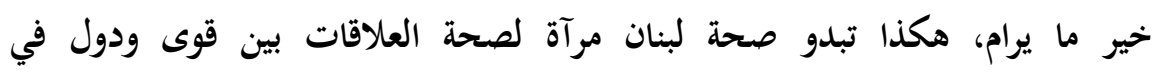

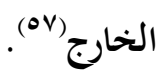
المطلب الاول: السياسات الاقليمية 


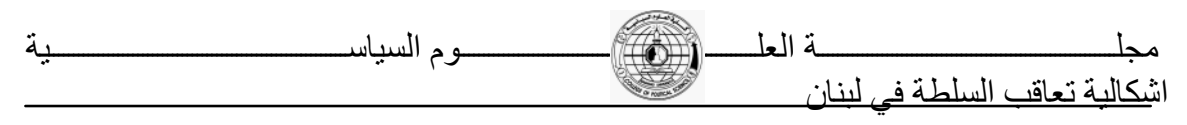

$$
\text { اولاً: سوريا }
$$

يمكن القول ان التدخل السوري في لبنان كان مبكرا، وبشكل مكثف أكثر من أي

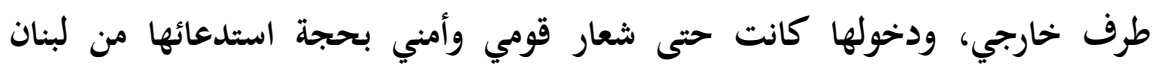

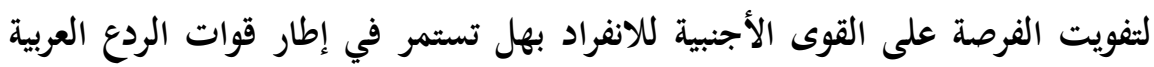

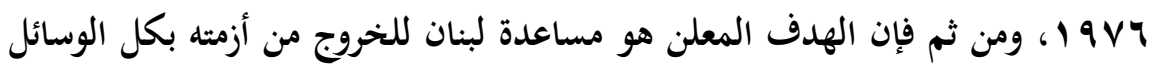

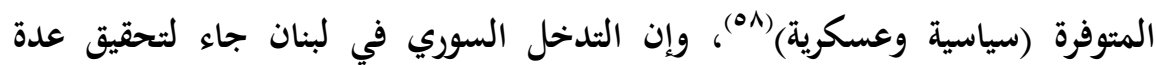

$$
\text { أهداف لعل أهمها: - الميانية }
$$

1- التدخل السوري في لبنان ناجم عن إدراك سوريا لأمنها القومي بعد هجمات

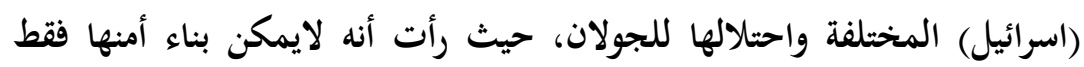

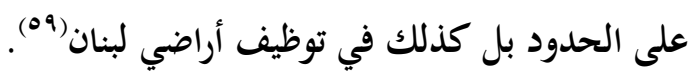
r- بعدما فقدت سوريا سيطرتها على الجولان، ظهرت حاجتها المتزايدة في استعمال

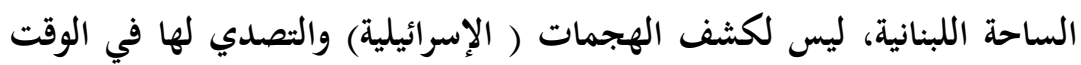

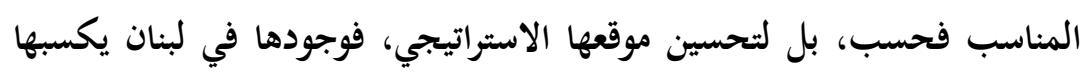

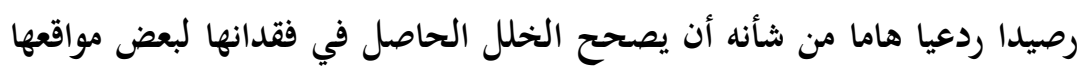

$$
\text { الاستراتيجية. }
$$

r- سعت سوريا من خلال تدخلها إلى الحفاظ على وحدة لبنان، ذلك أن سوريا تتأثر

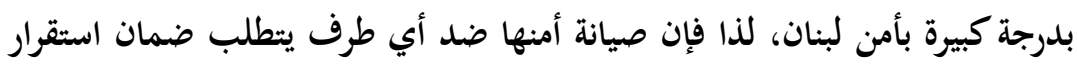

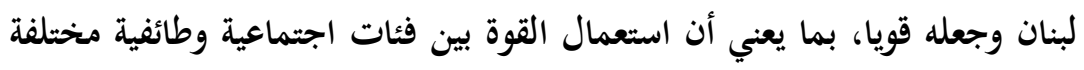

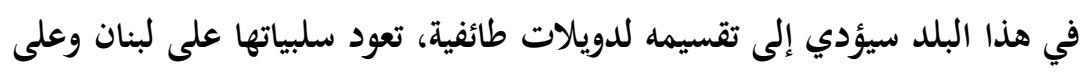

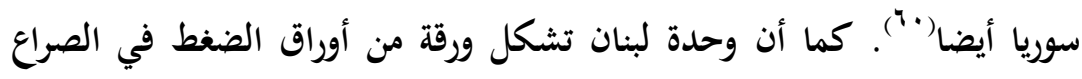

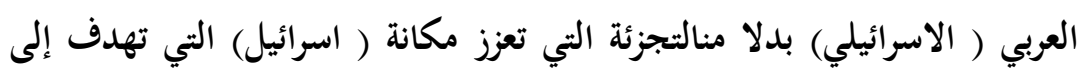
تقسيم لبنان إلى دويلات طائفية. 


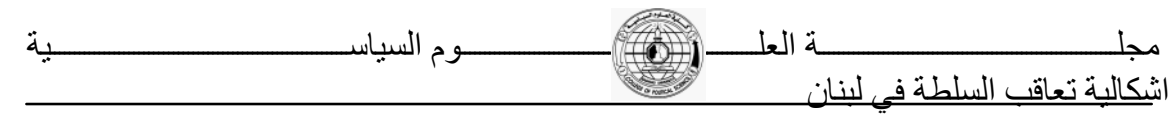

ع- تمثل الورقة اللبنانية بالنسبة لسوريا أحد عناصر قوتها في نطاق عملية التسوية

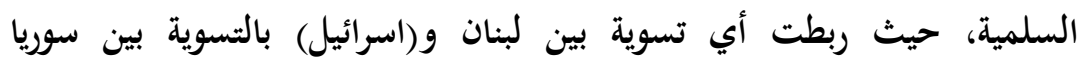

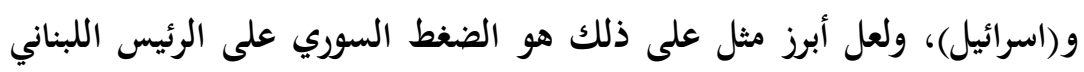

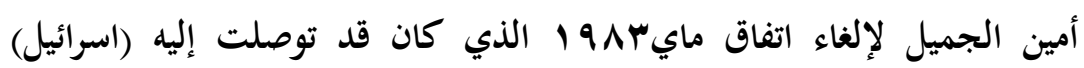

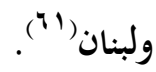

إن التدخل السوري في لبنان جعل سوريا حاضرة في كل الصدامات بين اللبنانيين،

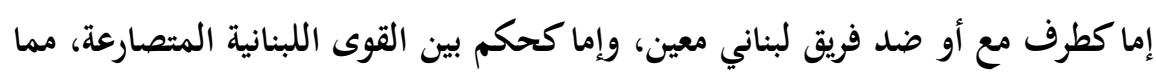

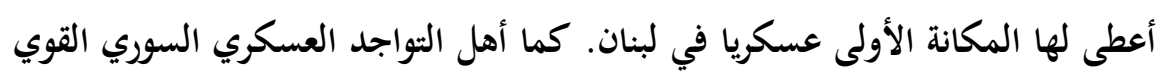

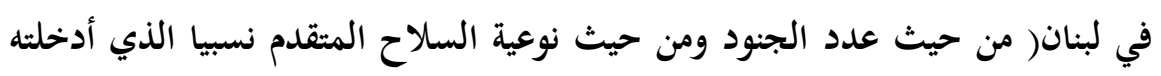

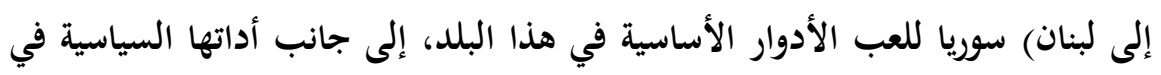

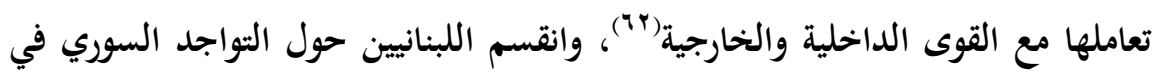

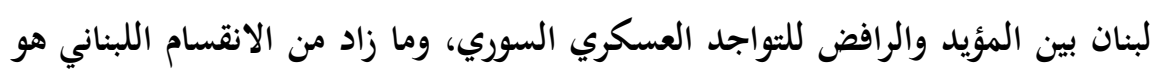

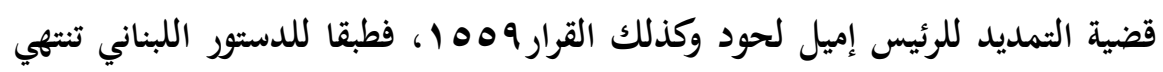

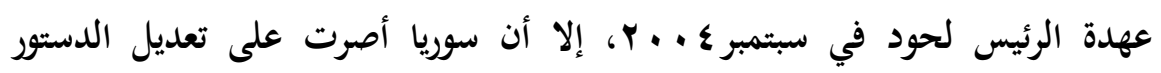

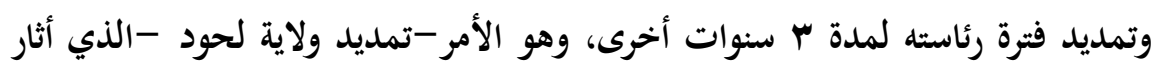

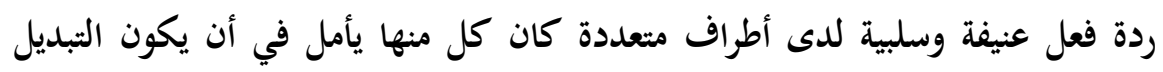

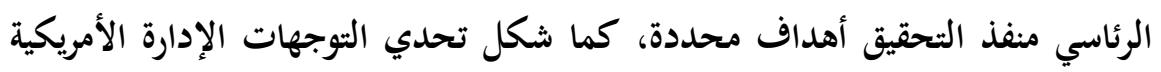

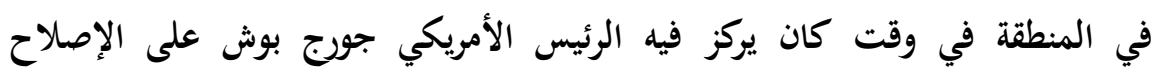

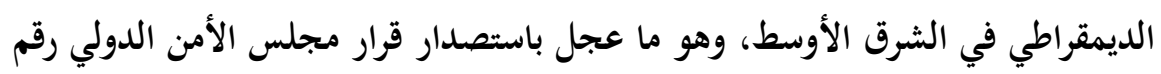

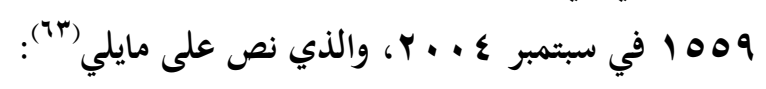

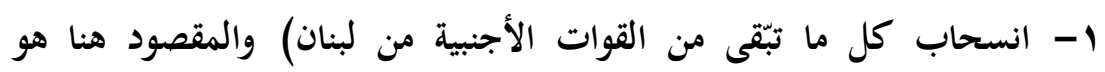

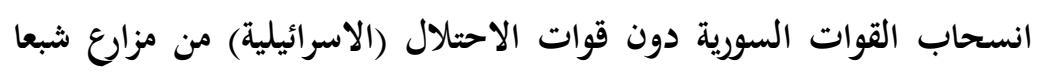

وفقا لعدم اعتراف الأمم المتحدة بأن مزارع شبعا تابعة للسيادة السورية. 


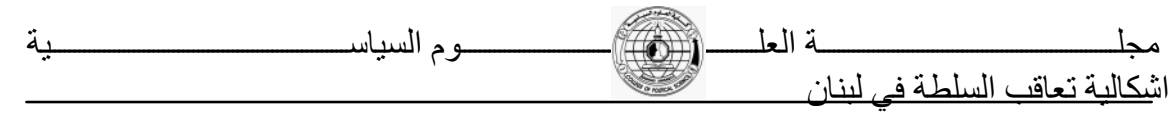

r- تفكيك ونزع سلاح كل الميليشيات اللبنانية وغير اللبنانية (حزب الله).

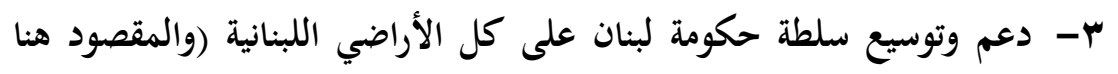

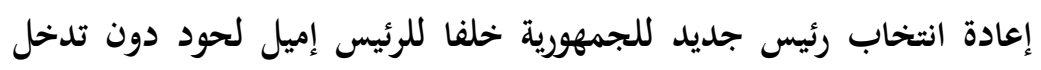

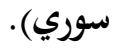
وكذلك انقسم اللبنانيون حول القرار بين مؤيد ورافض للقرار، ولكل من الطرفين حجج وملاحظات.

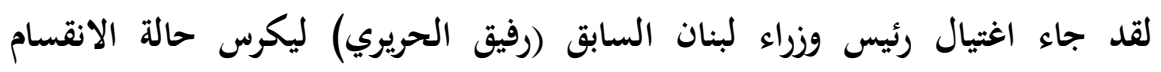

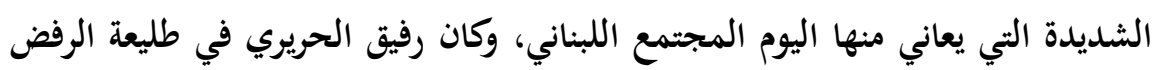

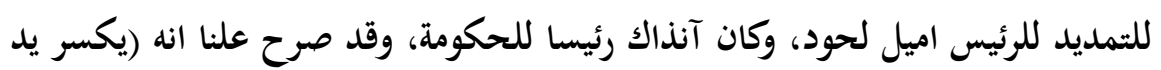

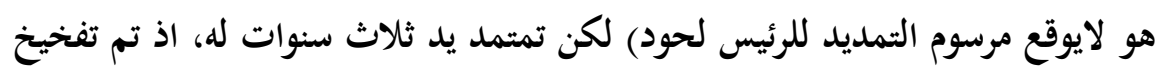

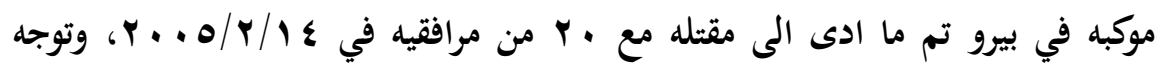

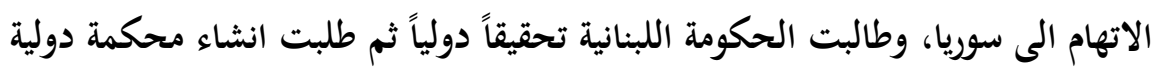

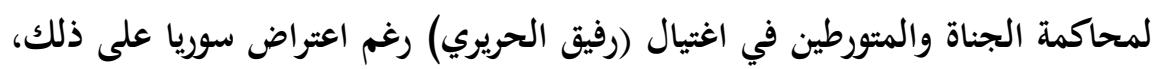
خوفا من تسييس المحاكمة واتهام النظام السوري بالوقوف وراءها، وعقب اغتيال التهال

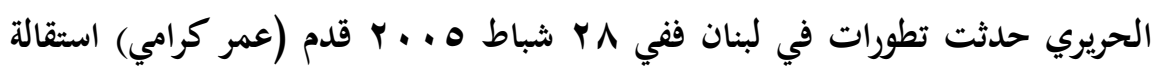

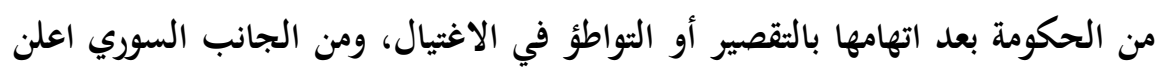

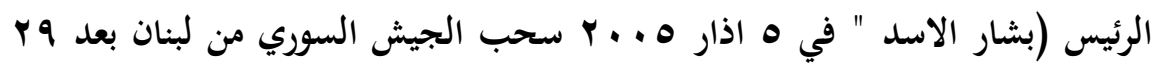

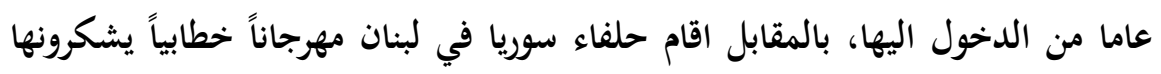

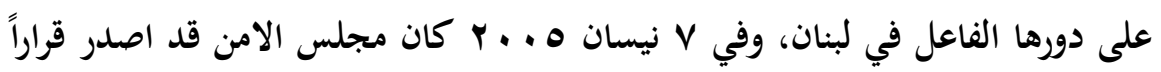

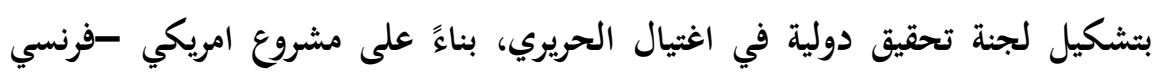

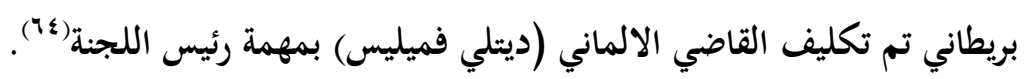

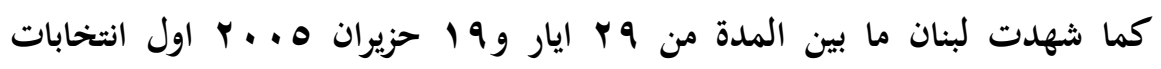

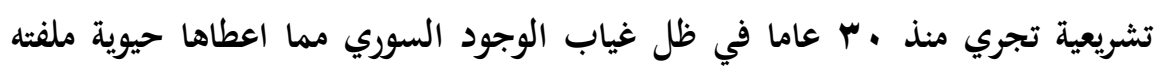




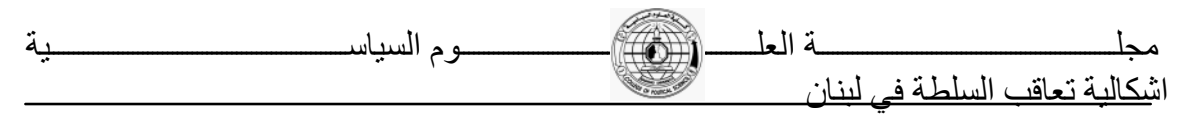

كلنظر، لان هذه الانتخابات تحررت من الهيمنة السورية(19)، لكن تبقى الأزمة السورية

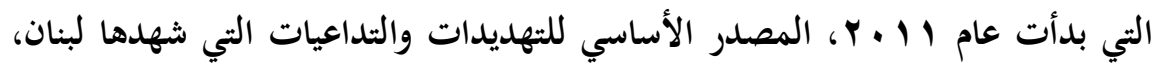

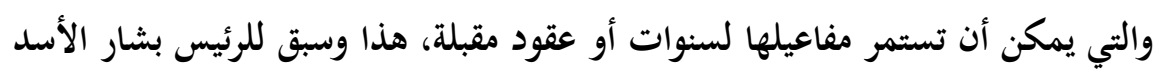

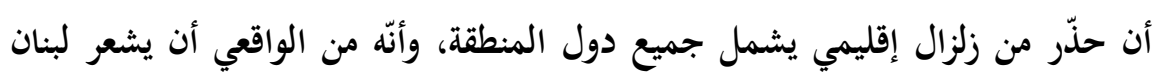

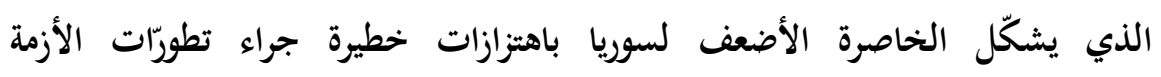

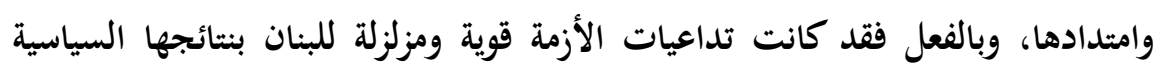

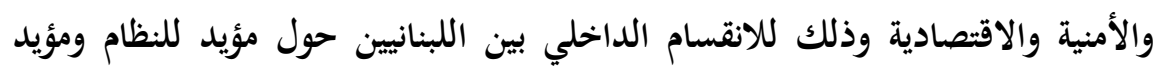

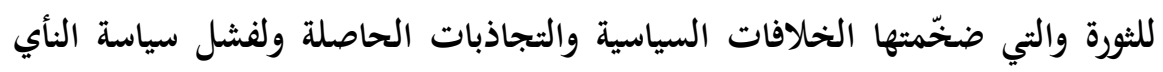

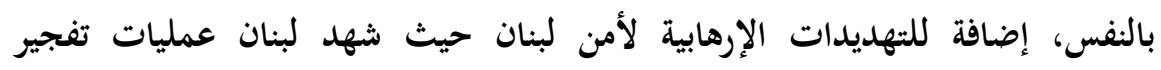

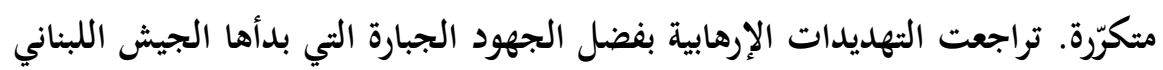

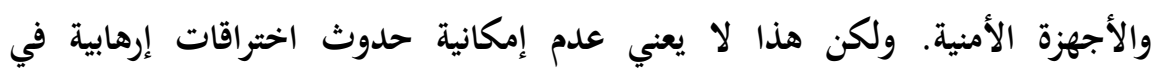

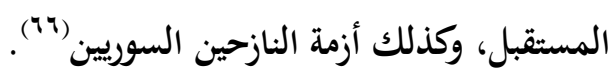

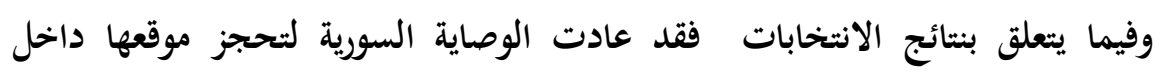

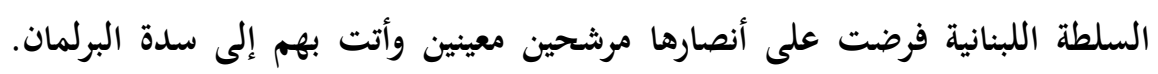

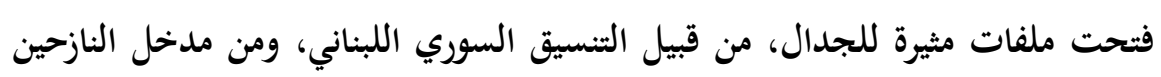

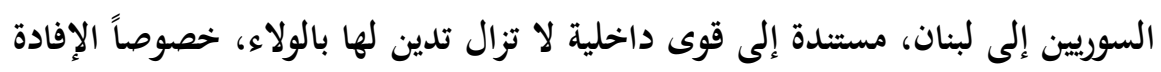

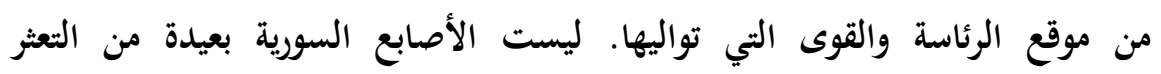

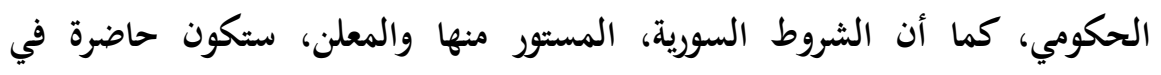

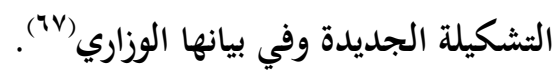
ثانياً: المملكة العربية السعودية

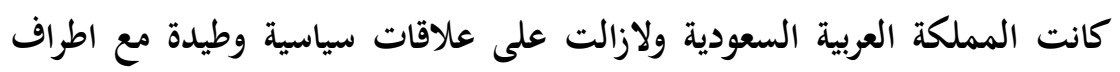

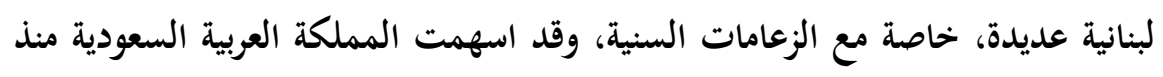

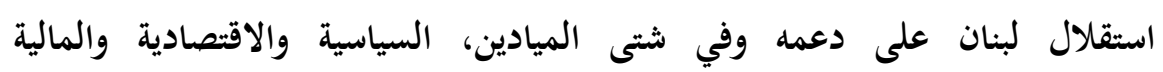

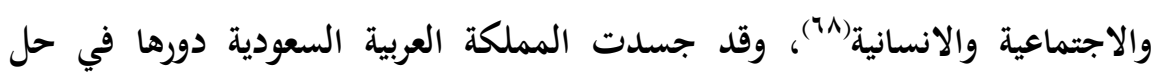




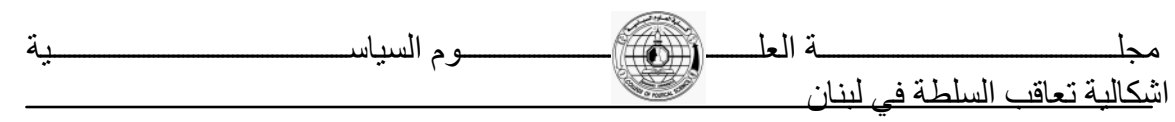

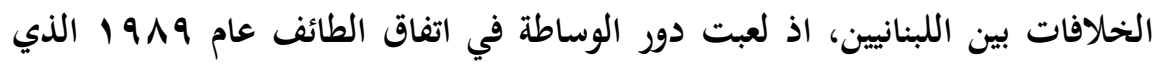

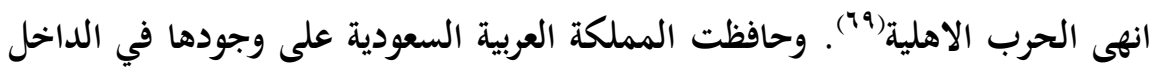

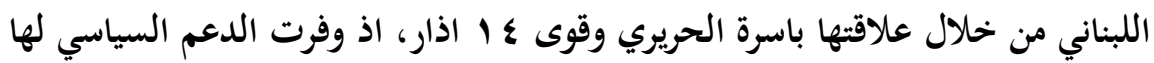

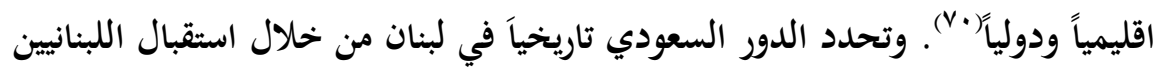
وتأمين فرص عمل لهم بما فيهم رئيس الوزراء الراحل رفيق الحريري، ومحاولة الهانياء

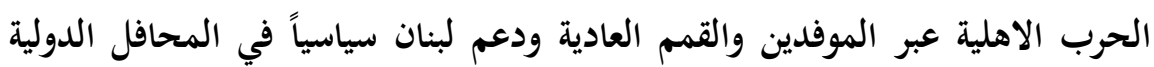

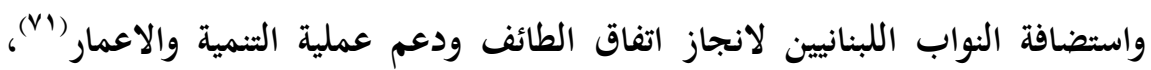
واستمر الدعم السعودي للفرقاء السياسيين في لبنان، على أثر العدوان ( الاسرائيلي)

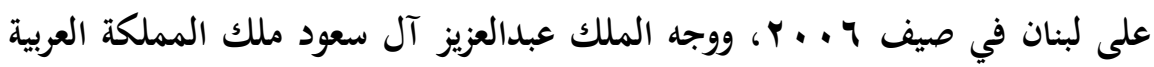

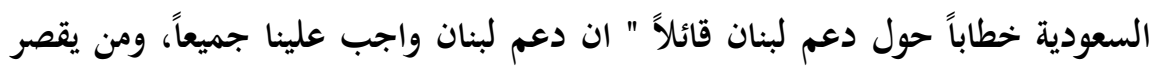

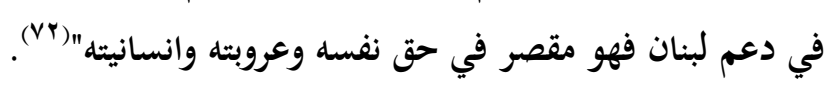

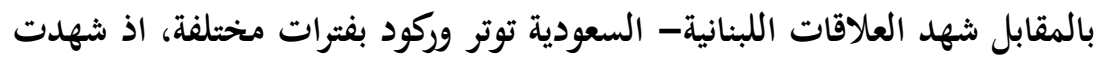

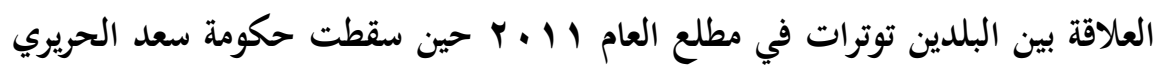

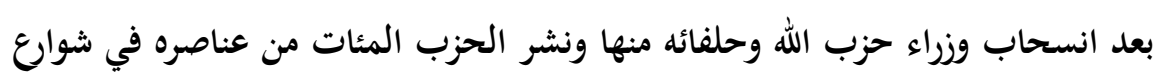

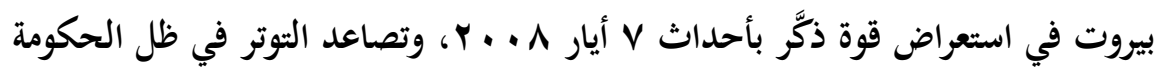

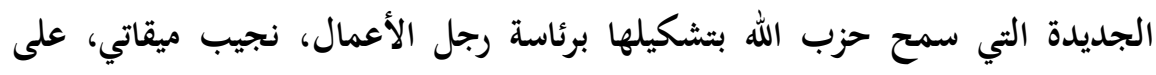

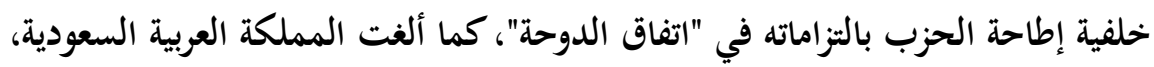

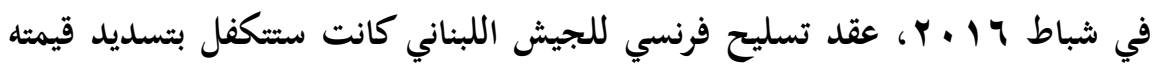

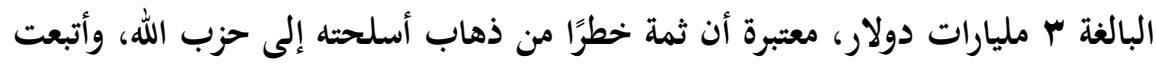

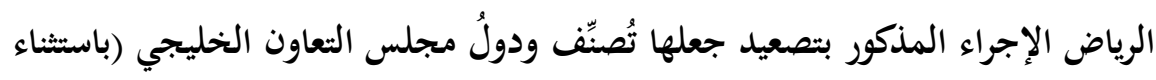

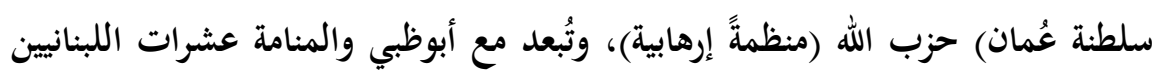

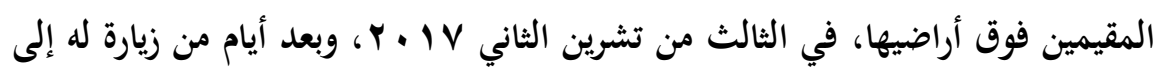

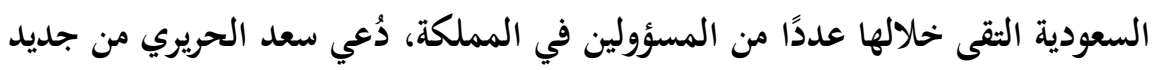

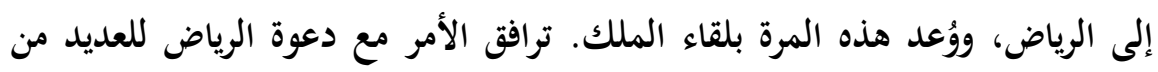




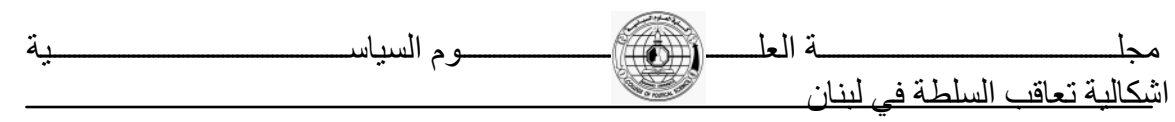

الأمراء ورجال الأعمال والمسؤولين السعوديين السابقين المقيمين في الخارج لزيارتها

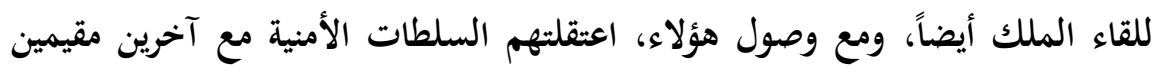

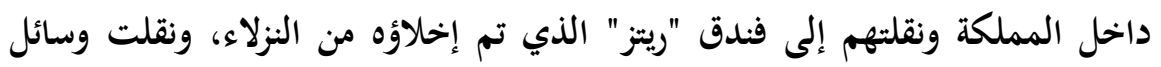

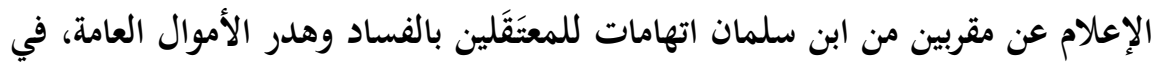

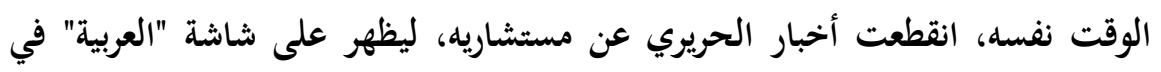

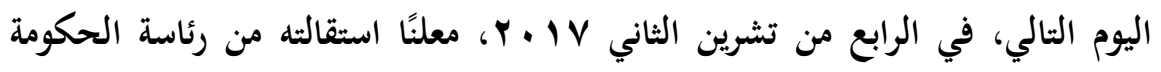

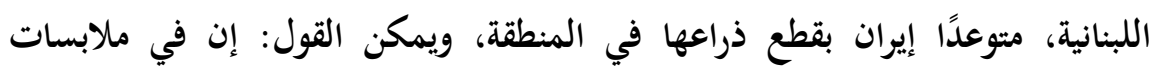

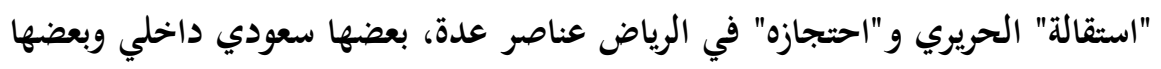

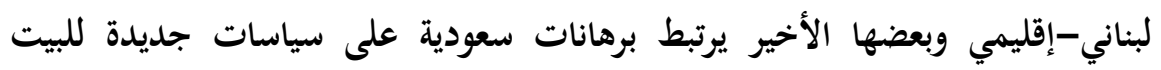
الأبيض تجاه المنطقة (V)".

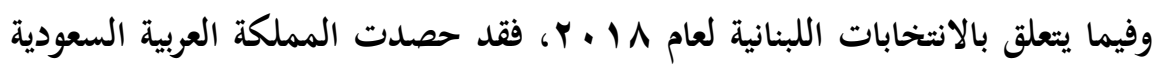

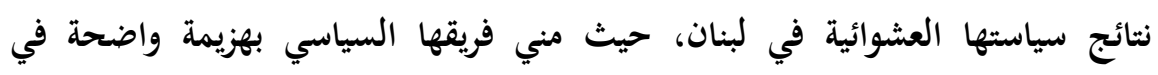

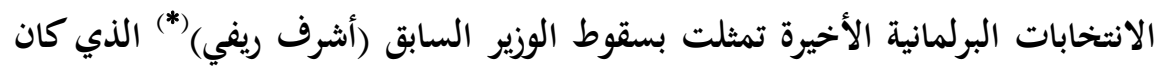

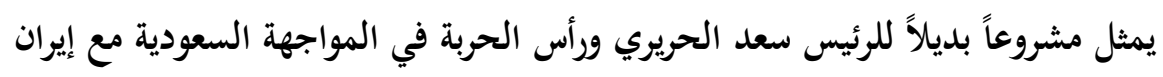

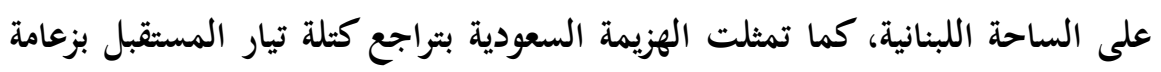
الحريري وسقوط عدد كبير من مرشحي قوى \& ا آذار، في المقابل تقدم النفوذ الإيراني

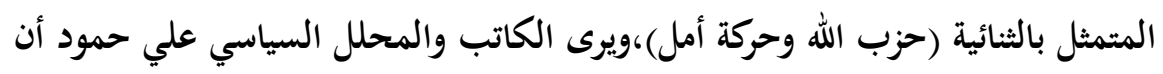

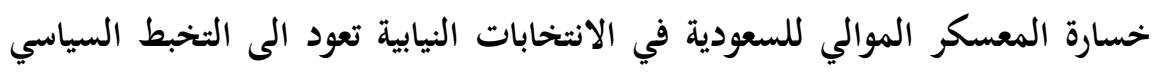

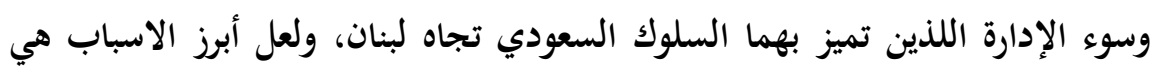

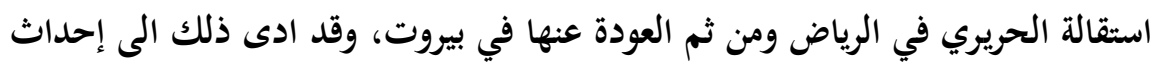

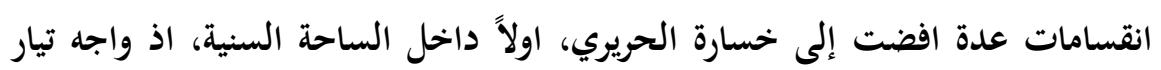

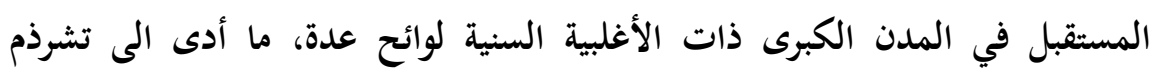

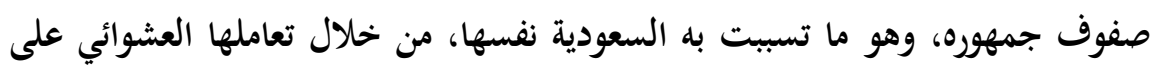

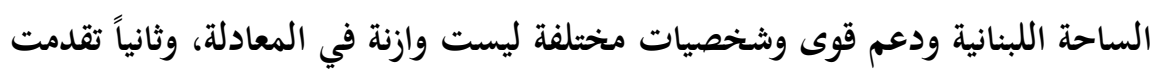




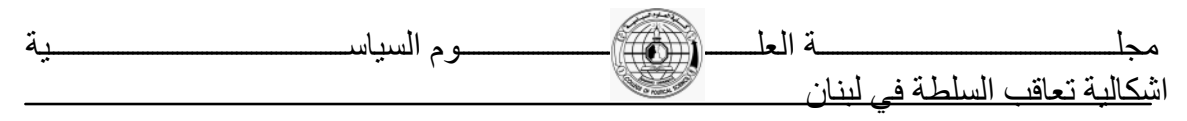

القوات اللبنانية ضمن تجمع \& ا آذار على حساب تيار المستقبل، وهنا يبرز أيضا

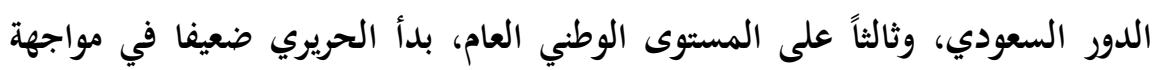

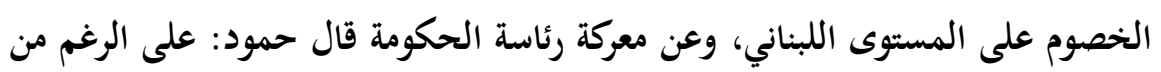

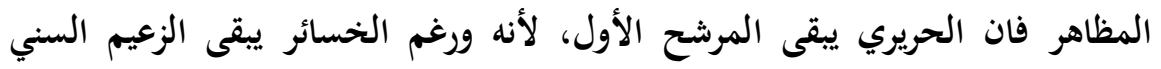

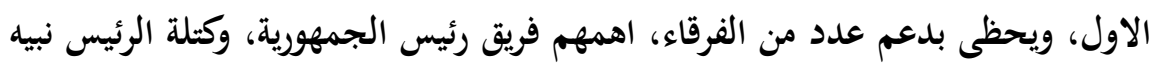

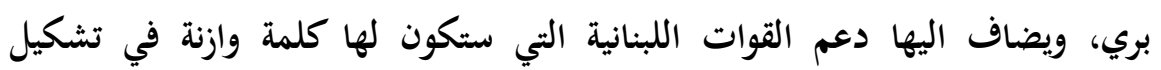

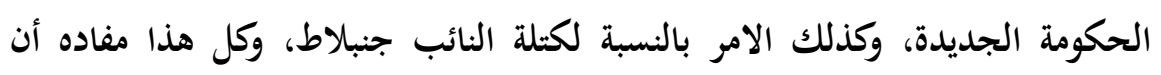

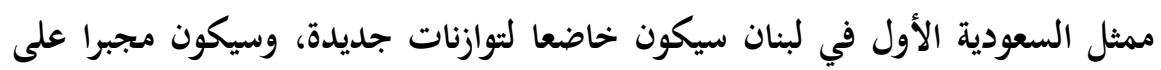

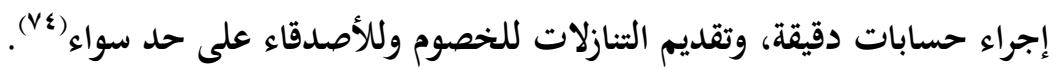

ثانياً: ( اسرائيل)

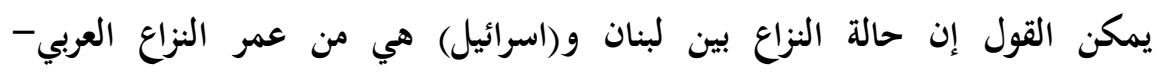

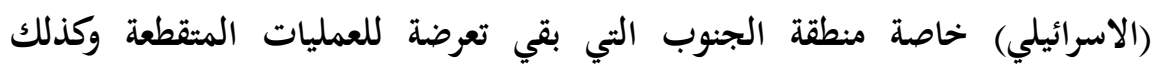

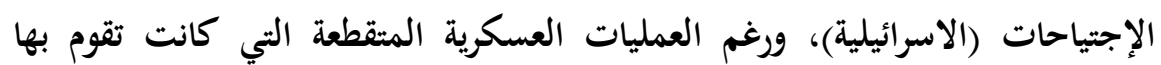

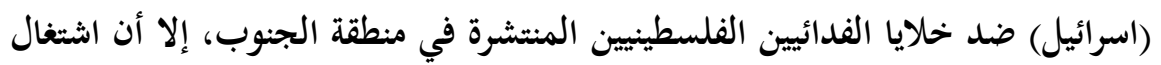

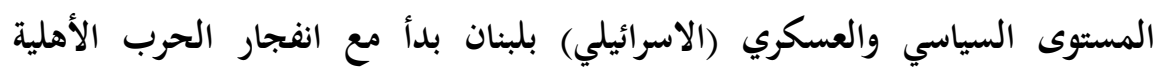

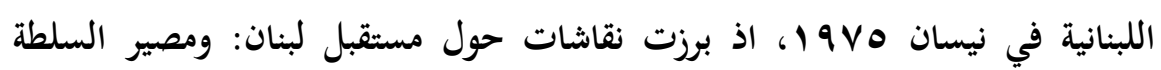

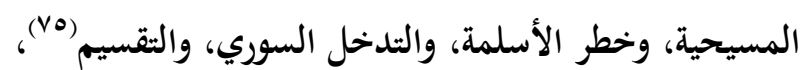

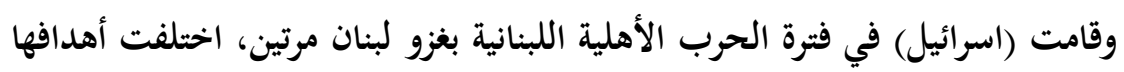

$$
\text { في كل مرة (vi). }
$$

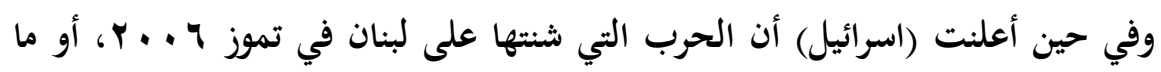

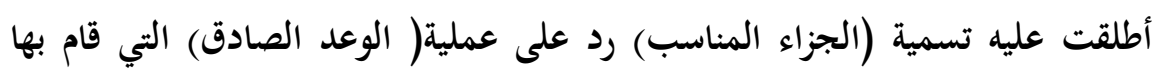

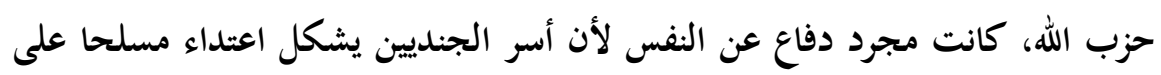




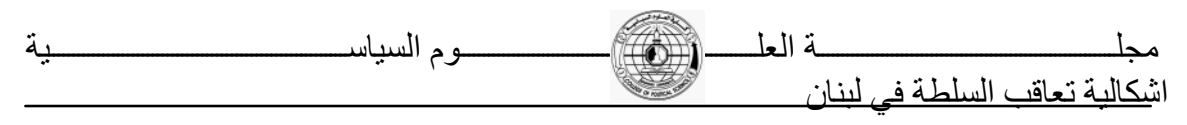

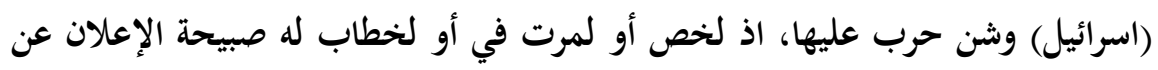

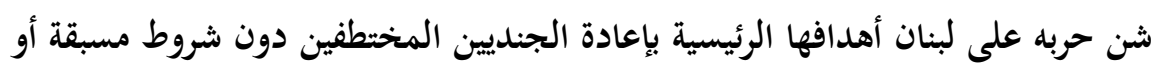

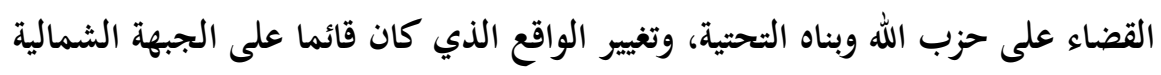

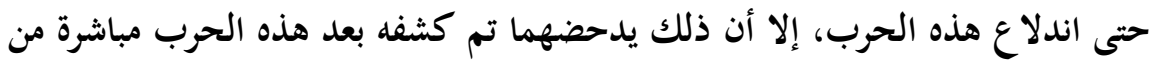

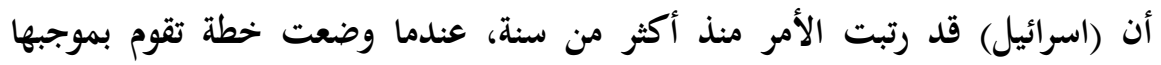

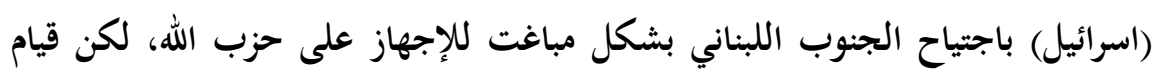

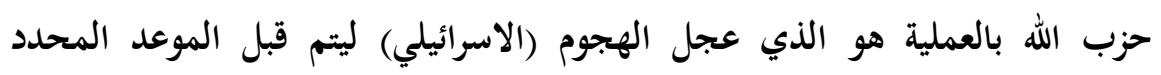
.(vv)d

وعموماً فان (اسرائيل) كانت تهدف من خلال عدوانها على لبنان تحقيق الاتي:(VA) . 1- تغيير قواعد اللعبة السابقة القائمة على (توازن الرعب) وخلق توازنات جديدة في لبنان والمنطقة. r- ت بحرير الجنديين الأسيرين من قبضة حزب الله من دون شروط.

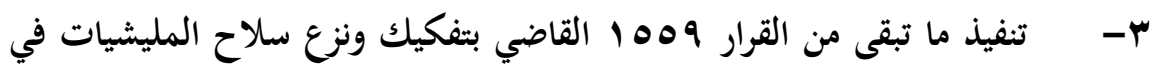
لبنان. ع- القضاء على حزب الله سياسياً عبر تصفية قياداته جسدياً والقضاء على قدراته

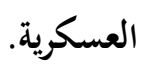
ه- القضاء على البنة التحتية الاجتماعية والخدمية للحزب.

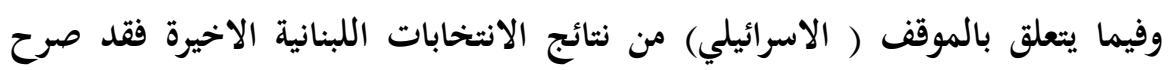

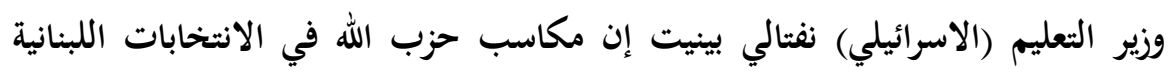

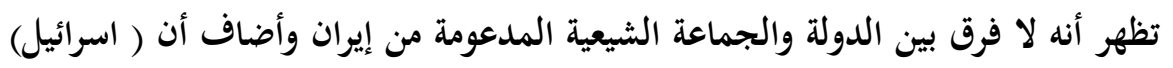

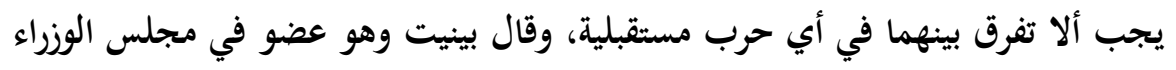

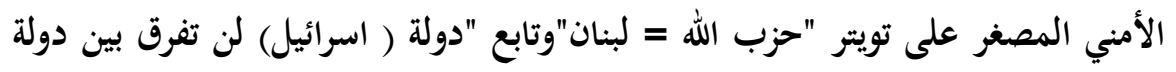




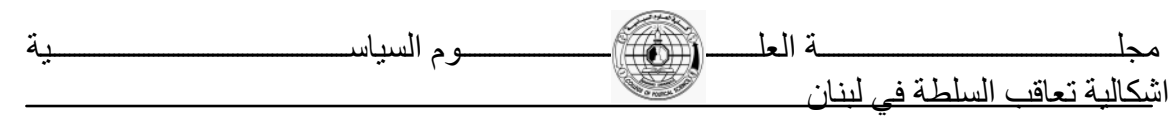

لبنان ذات السيادة وبين حزب الله وستعتبر لبنان مسؤولا عن أي عمل داخل

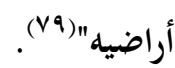
ثالثاً: ايران

اما بخصوص ايران فان لها تاريخ متجذر في منطقة الشرق الاوسط، ولها امتدادات

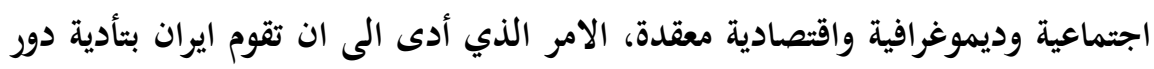

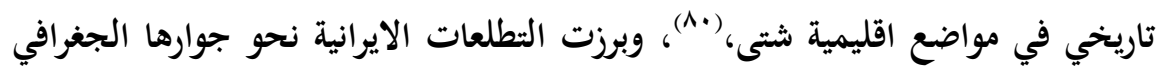

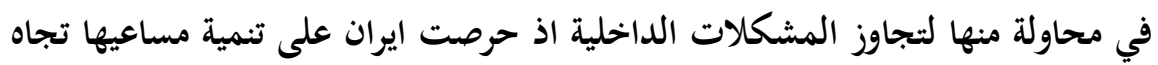

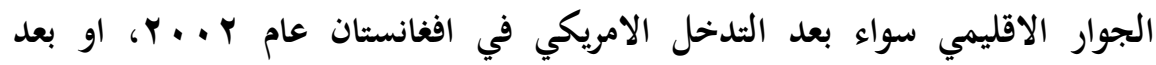

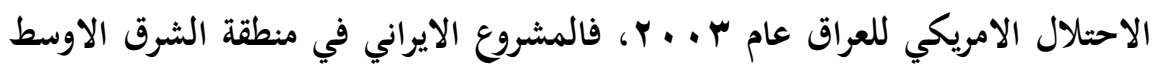

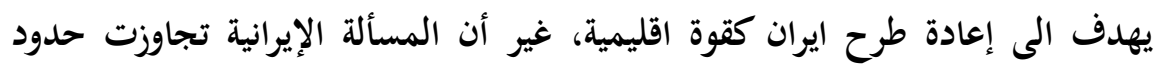

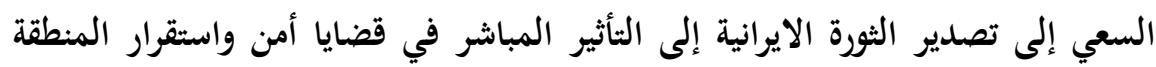

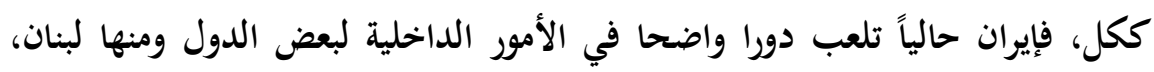

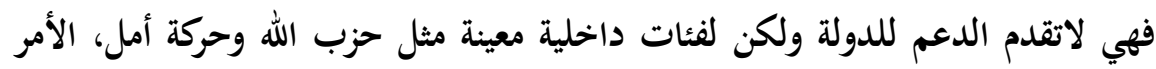
الذي يهدد الشرعية السياسية لهذه الدولة ويخلق أزمات داخلية (1).

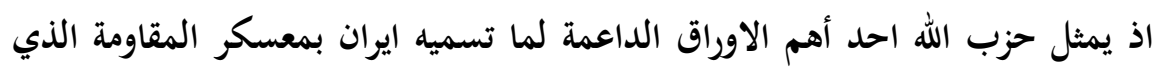

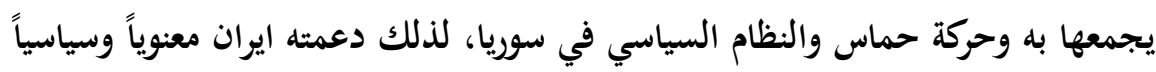

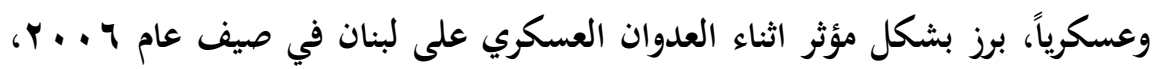

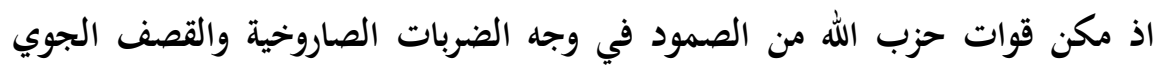

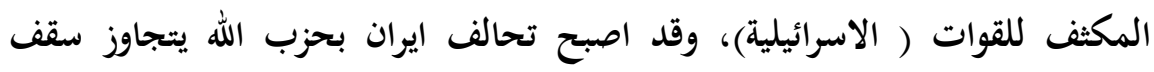

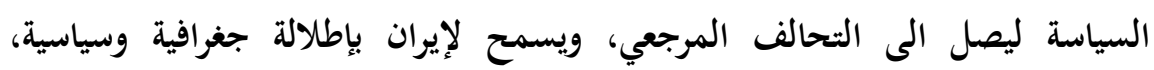

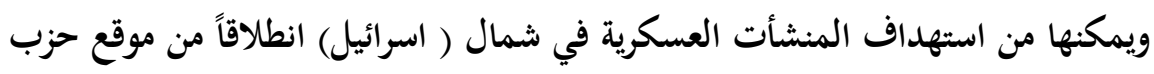

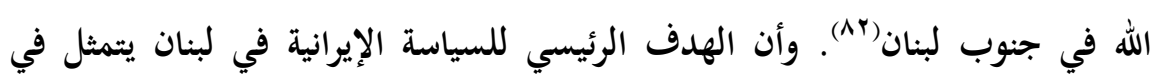

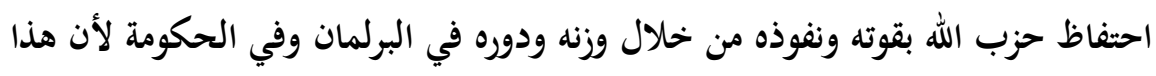

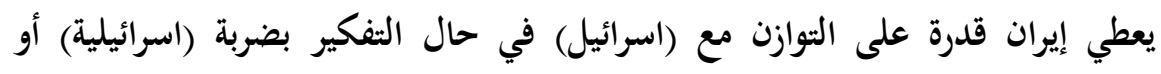




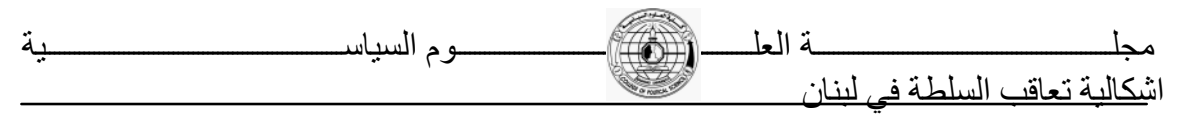

أمريكية لإيران فإن جبهة جنوب لبنان هي المرشحة للاشتعال والرد العنيف إلى قلب

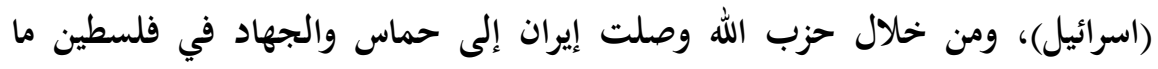

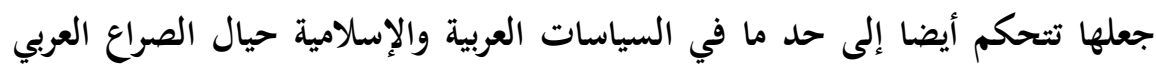

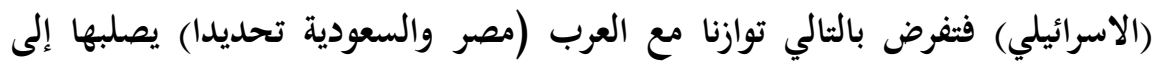

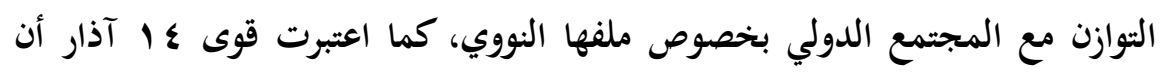

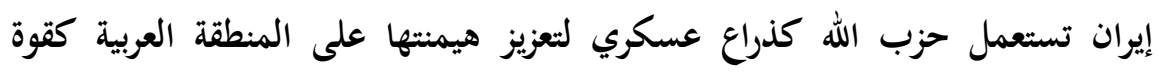

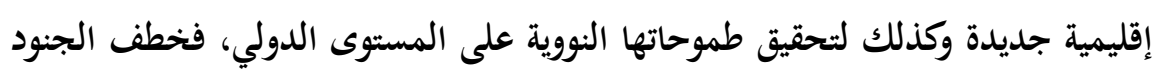

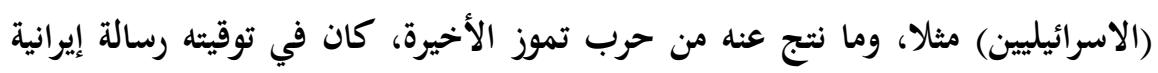

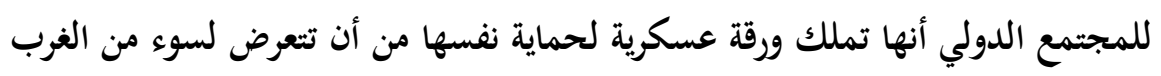

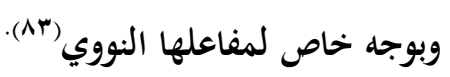

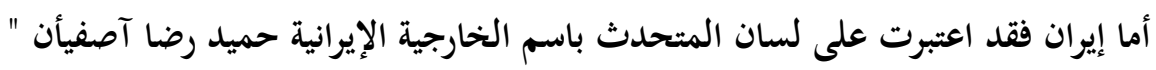

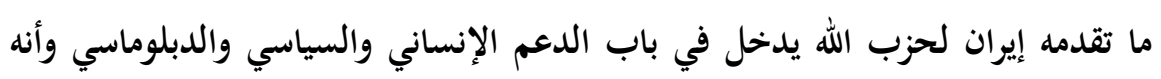

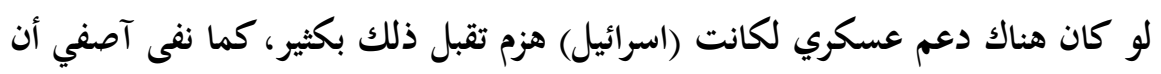

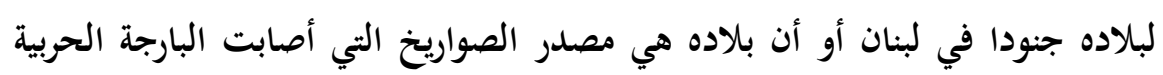

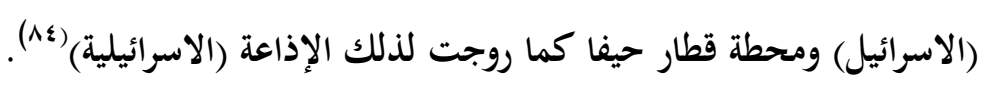

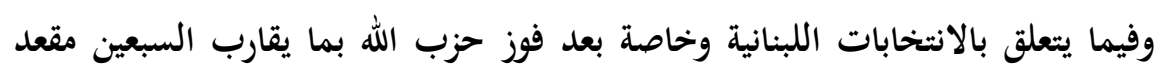

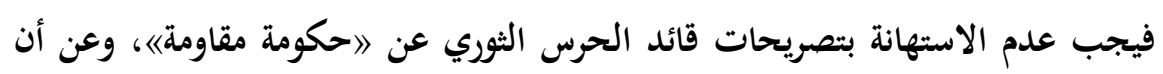

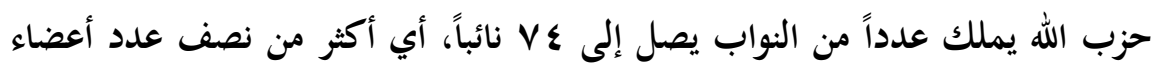

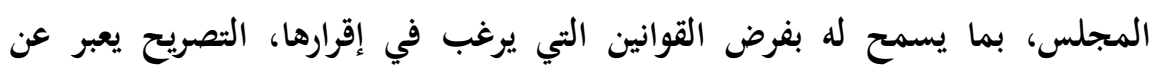

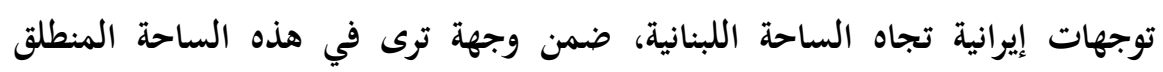

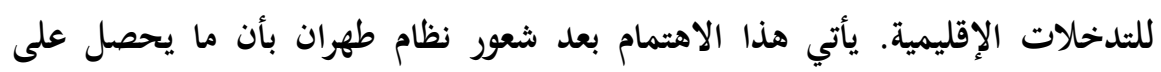

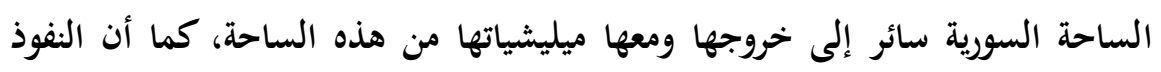

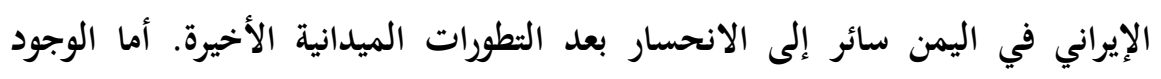

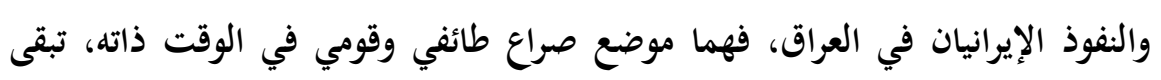




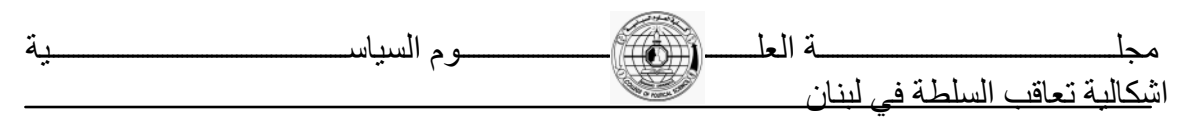

الساحة اللبنانية الوحيدة الهائة، وتملك فيها النفوذ بلا منازع، وعندما احتسب الكبان

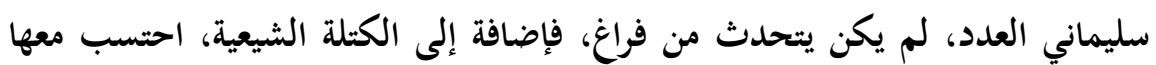

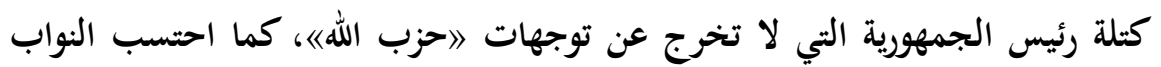

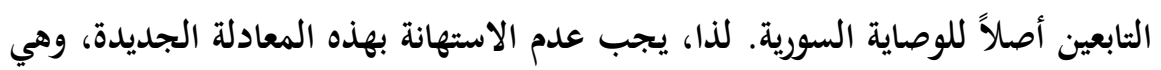

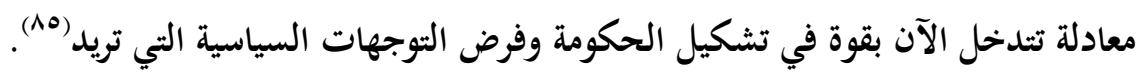
المطلب الثاني: السياسات الدولية

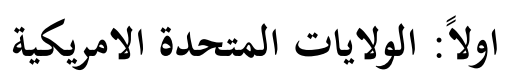

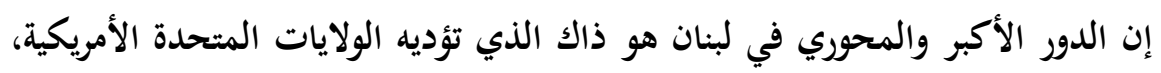

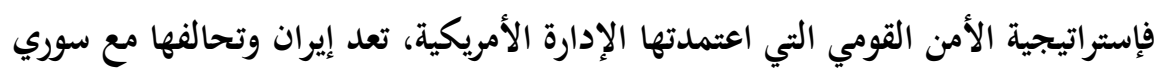

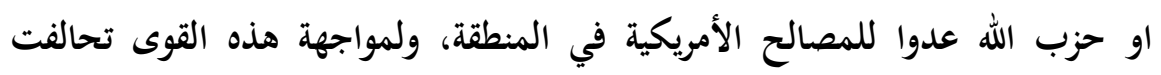

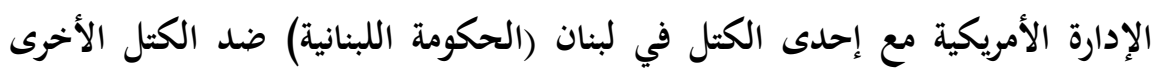

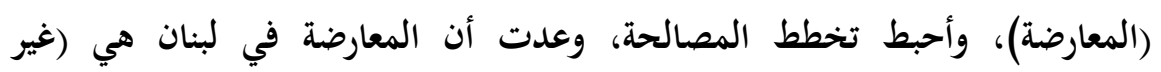

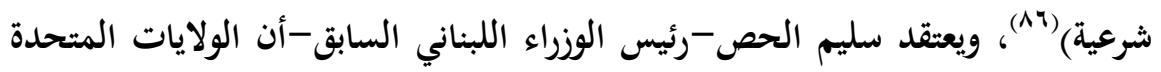

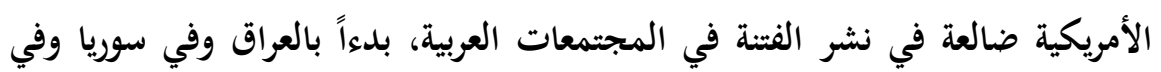

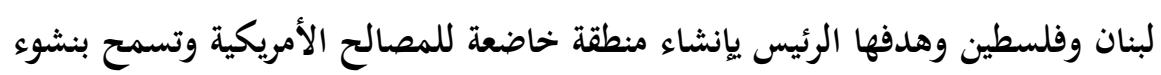

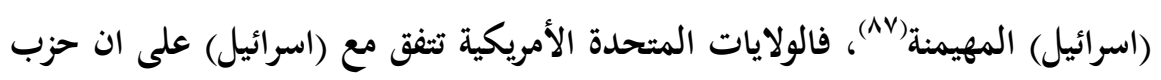

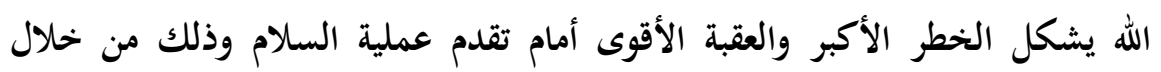

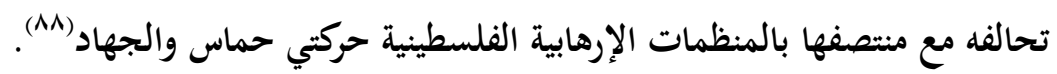

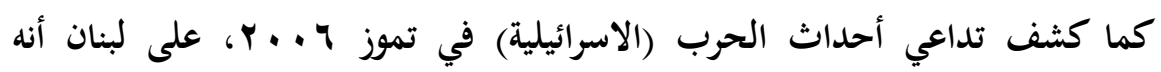

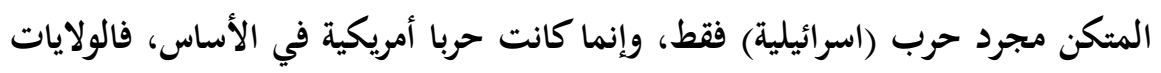

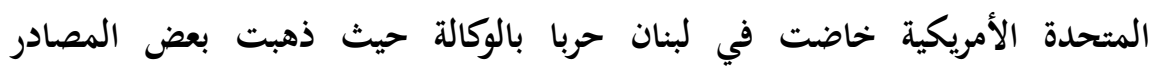

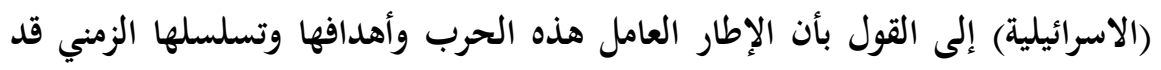

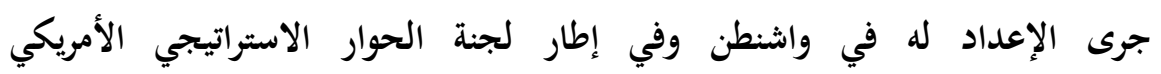




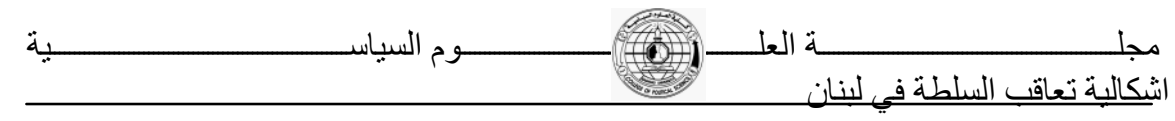

(الاسرائيلي)(م9)، ويؤكد هذا الأمر ما جاء على لسان مستشار في وزارة الدفاع من أن

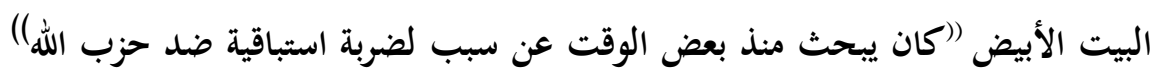

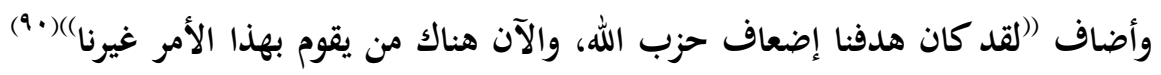

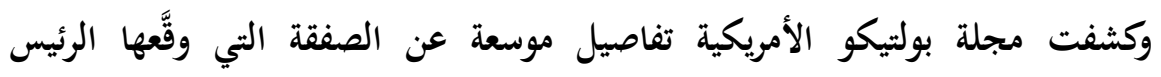

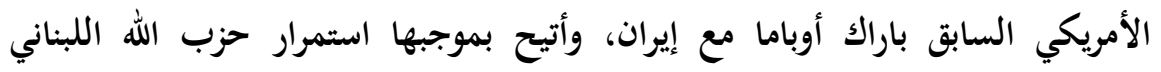

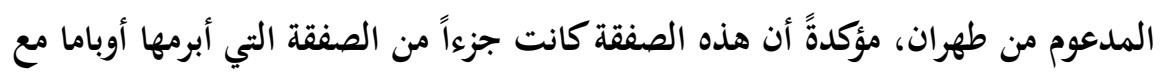

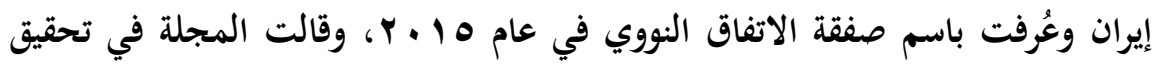

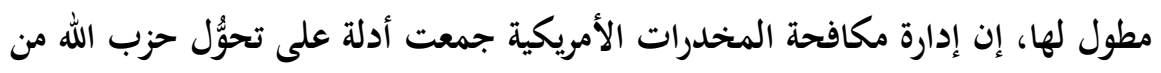

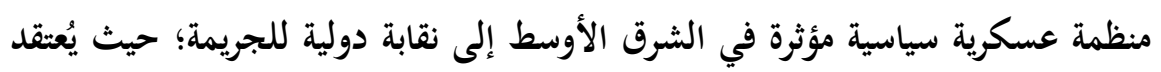

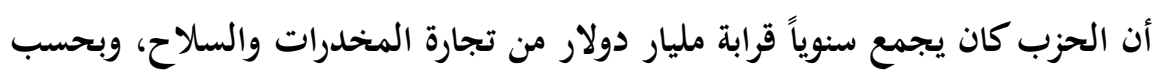

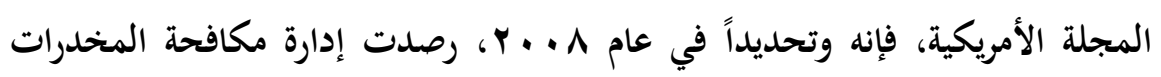

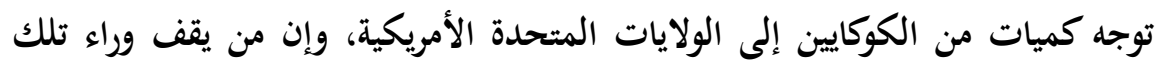

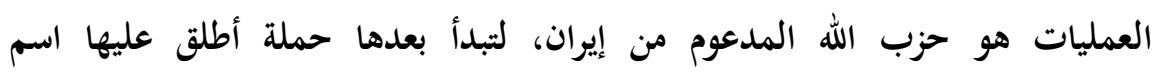

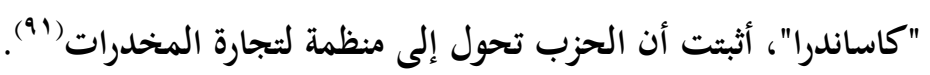

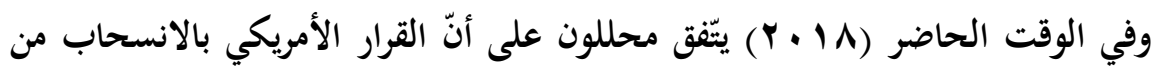

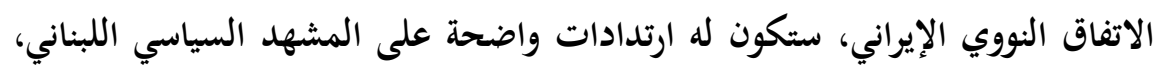

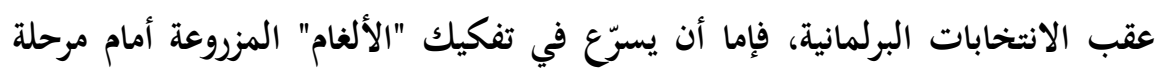

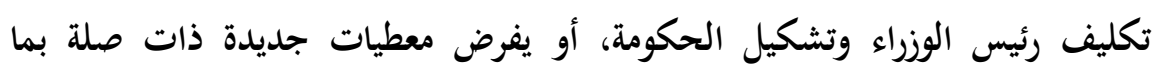

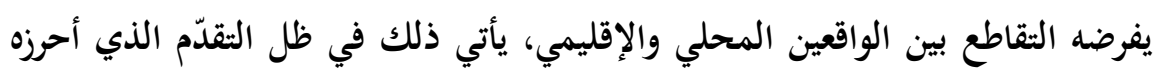

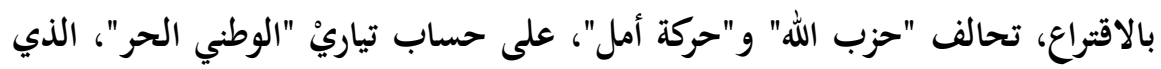

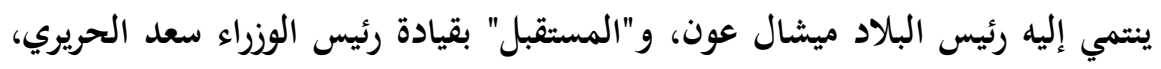

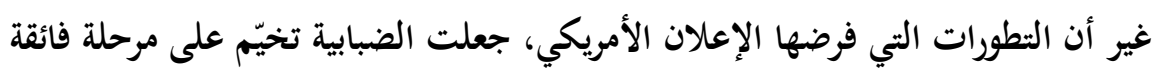

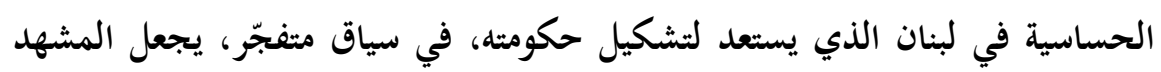

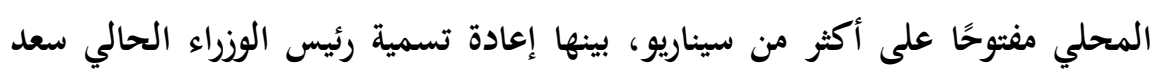




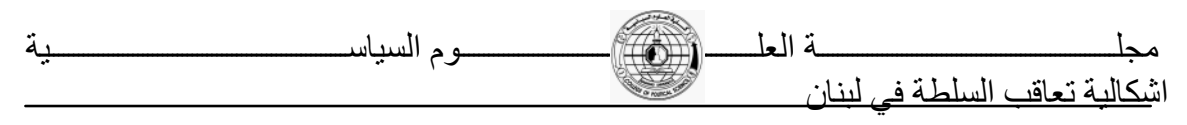

الحريري، لتشكيل الحكومة، وذلك رغم امتلاك "حزب الله" الغالبية، وهو ما حصل

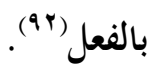

الباحث اللبناني وليد الأيوبي، اعتبر في حديث للأناضول، أن انسحاب واشنطن من الاتفاق الإيراني ، يشكّل "استدارة كبيرة ونقطة تحوّل في المنطقة"، الأيوبي أشار أن الن النيان

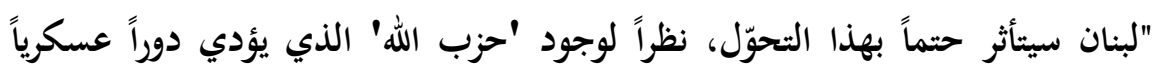

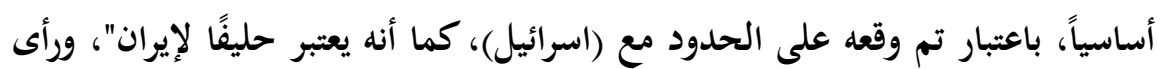

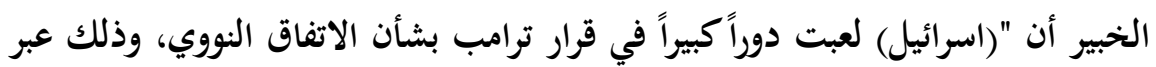

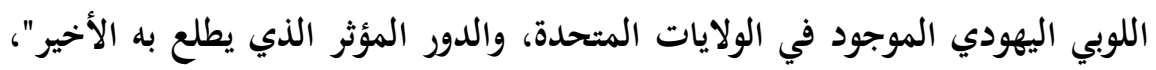

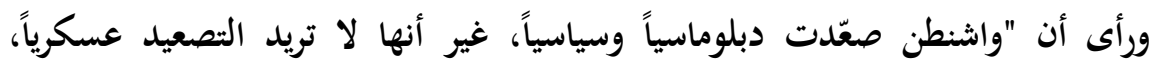

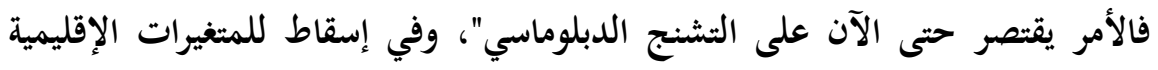

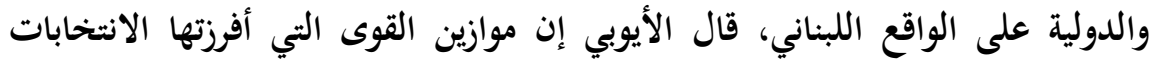

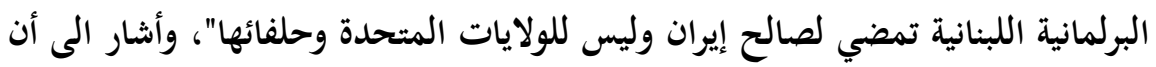

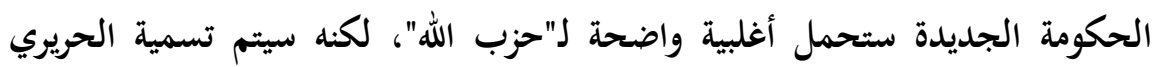

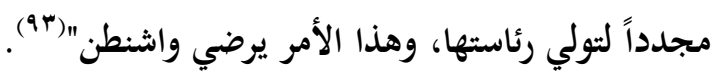

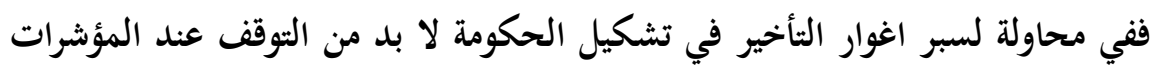
الخارجية التالية:(9).

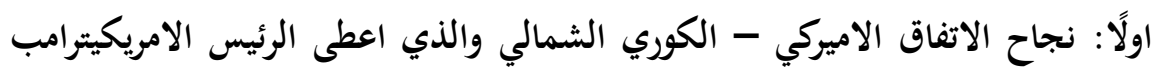

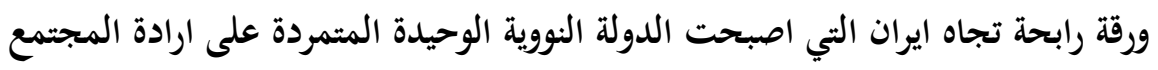

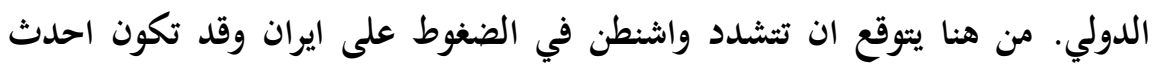

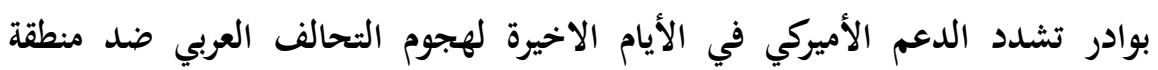
الحديدة اليمنية الاستراتيجية لأسقاط واحدة من اهم اوراق ضغط ايران (عبر الحير الحوثيين)

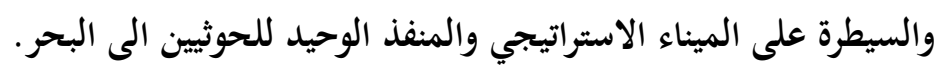

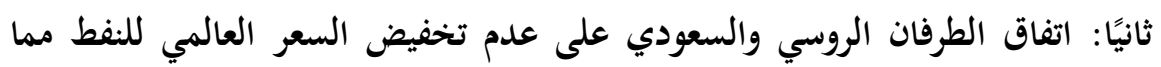

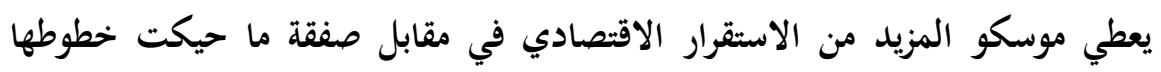




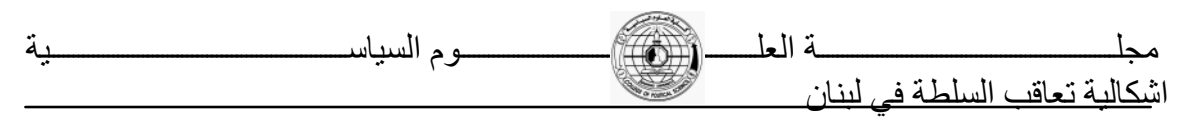

العريضة، باتجاه التضييق على الوجود الايراني من خلال تولي موسكو الضغط على فلى

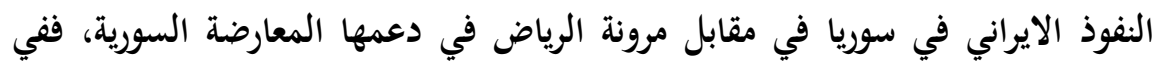

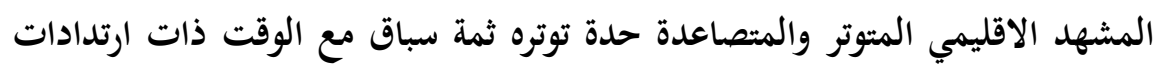

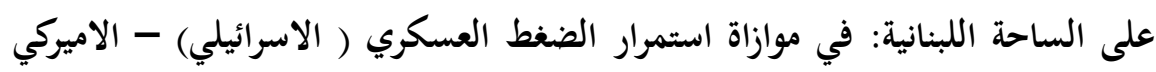

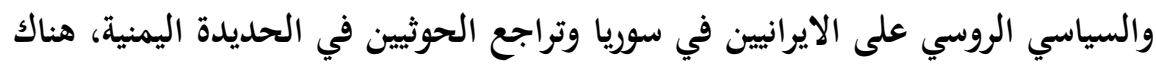

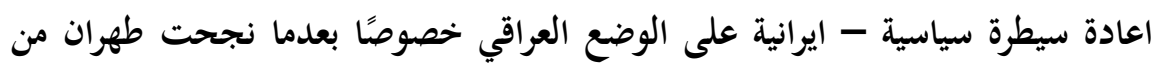

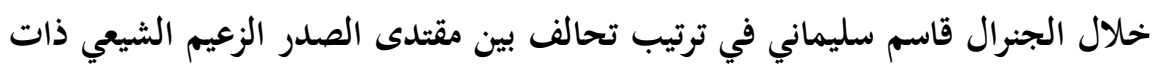

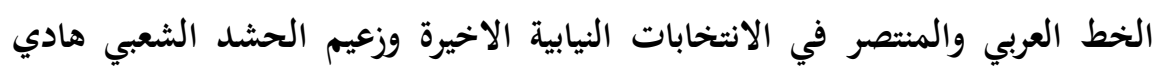

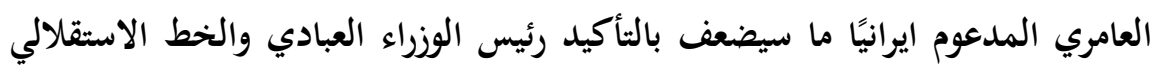

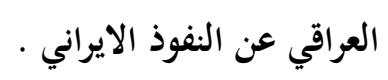

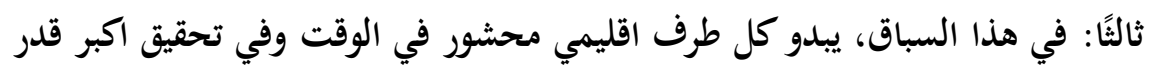

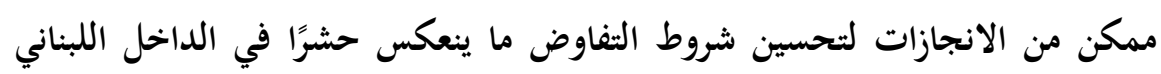

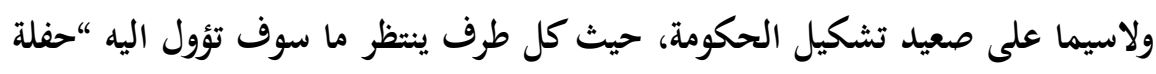

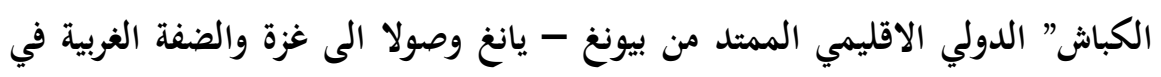

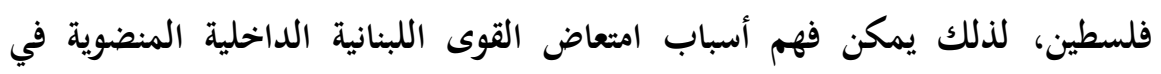

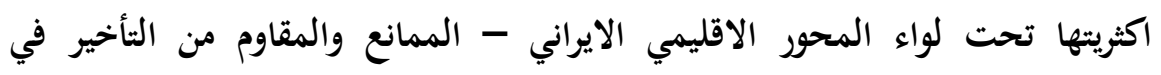

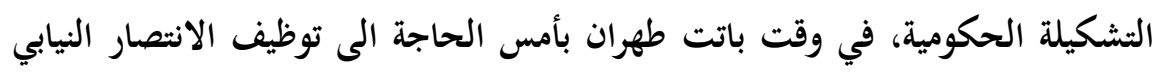

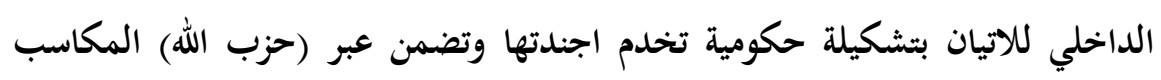

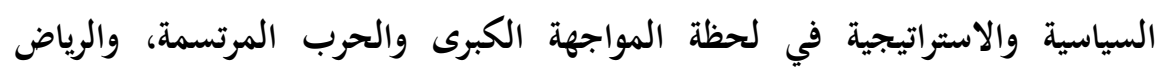

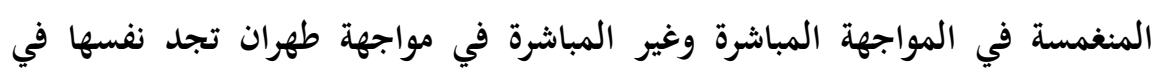

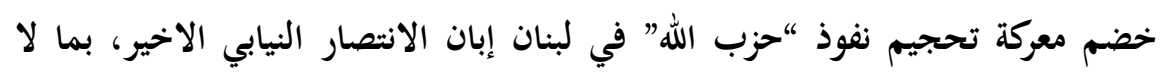
يسمح بتشكيل حكومة مقاومة موالية سياسيًا لايران.

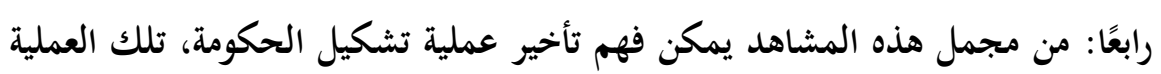
الواقفة اليوم امام مفترق طرق متناقضة ومتصارعة في لحظة ارتسام معالم الحسابات 


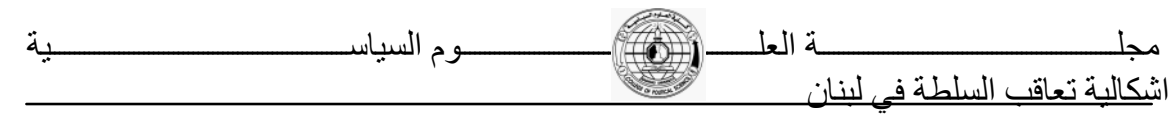

الدولية والاقليمية المتصادمة وتكريسها على ارض واقع الجبهات العربية المندلعة بدءًا

$$
\text { ثنانياً: فرويا }
$$

تعتبر فرنسا اللاعب الدولي الأول على الساحة اللبنانية منذ إصدار الدستور اللبناني لعام

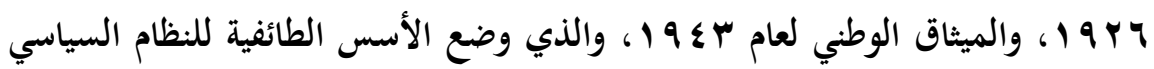

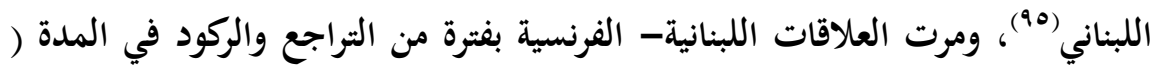

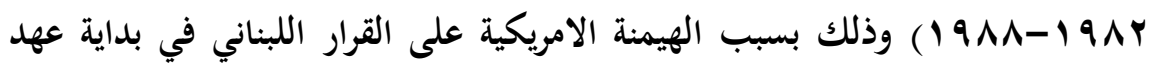

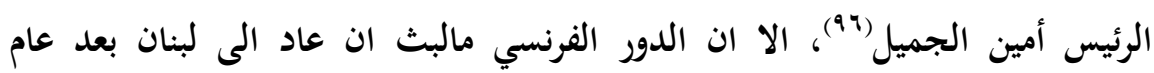

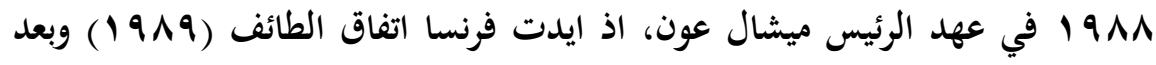
رحيل ميشال عون ووصول إلياس الهراوي الى رئاسة الجمهورية تراجع الدور الفرنسي

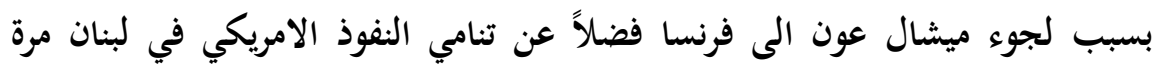

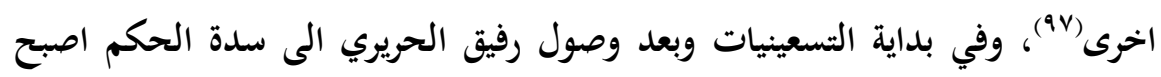

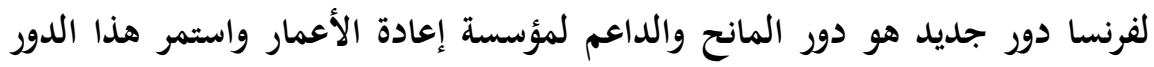

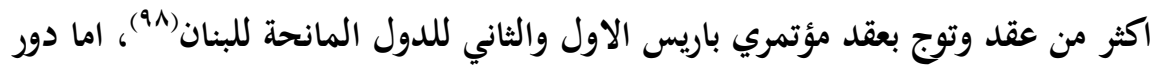

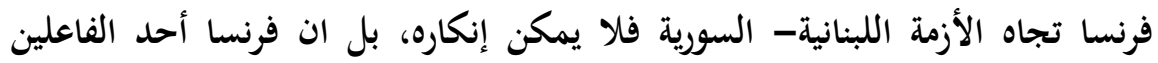

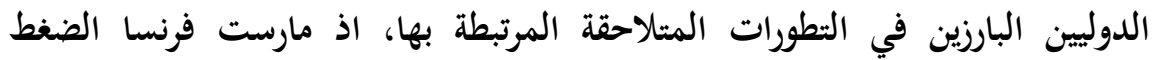

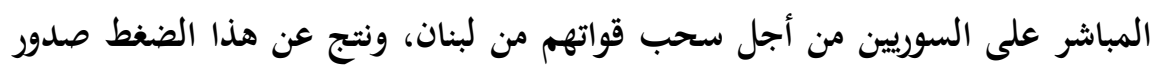

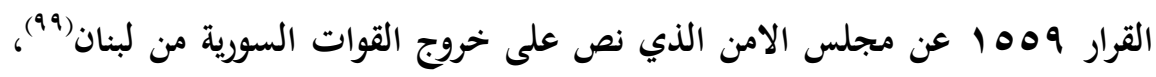

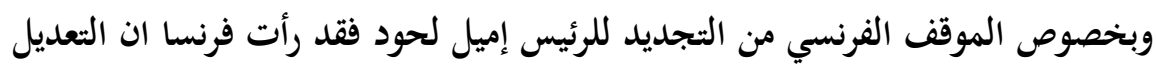
الدستوري بتجديد ولاية لحود شكل تحدياً للمجتمع الدولي وفتح الباب امام تطورات

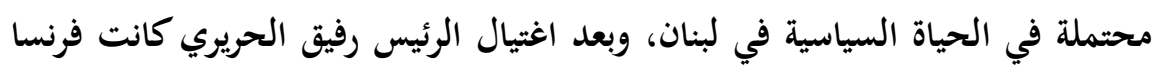

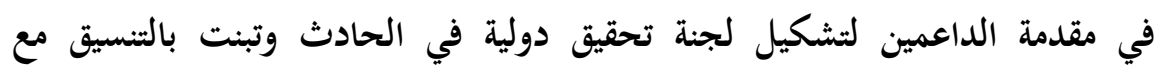
الولايات المتحدة الامريكية وبريطانيا مشروع قرار يقضي بتشكيل هذه اللجنة لُ.'). 


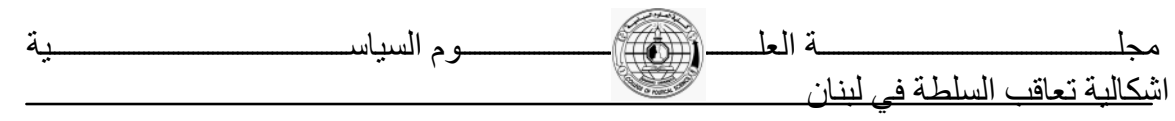

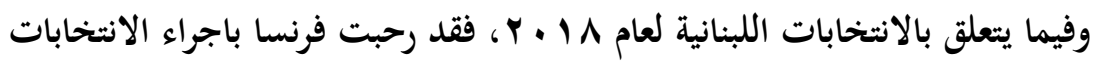

التشريعية في لبنان والتي جرت للمرة الأولى منذ تسع سنوات، وقالت المتحدثة الرسمية باسم وزارة الخارجية الفرنسية أني يسفوندير مول في تصريح لها، إن بلادها تهنىء لبنان

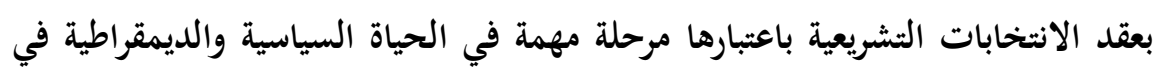

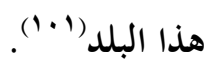

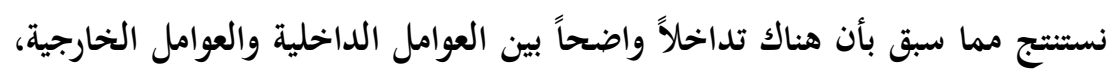
اذ ان سبب الازمات الداخلية في لبنان هو العامل الخارجي، فالتركيبة الاجتماعية

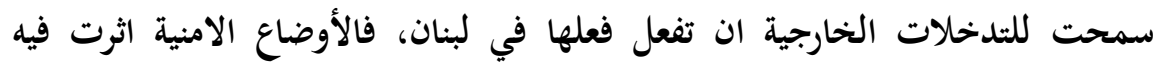

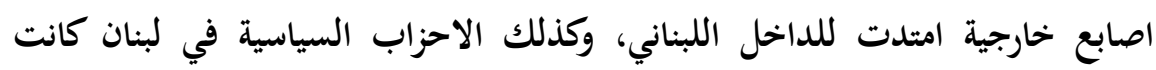

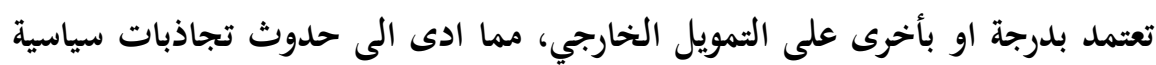

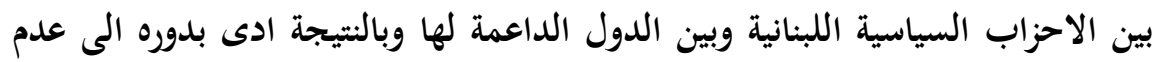
الاستقرار السياسي في لبنان.

الخاتمة

في ضوء الطرح السابق نجد ان لبنان عاشت وتعيش في ظل اوضاع صعبة ناجمة من

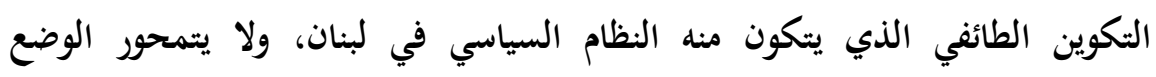
السياسي في لبنان حول الدولة بل حول المجتمع، مما جعل لبنان محوراً أساسياً في لئي ظلال تخطيط الاقليمي والدولي، وادى ذلك الوضع الى وقوعها في فخ الطائفية السياسية الذي انعكس بشكل واضح على النظام السياسي اللبناني وعلى التشكيل

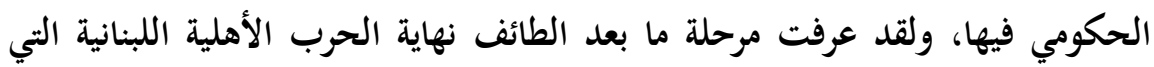

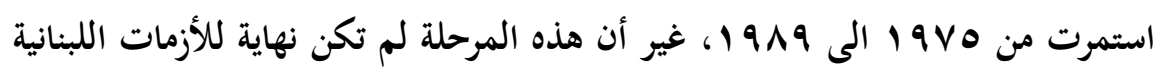

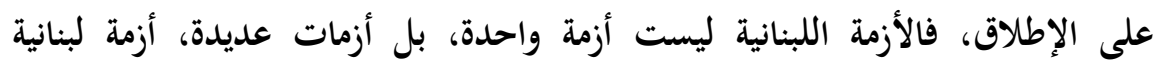
داخلية، أزمة مرتبطة بالعلاقات السورية اللبنانية، النزاع اللبناني (الاسرائيلي)، ولهذا،

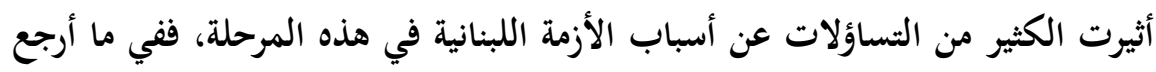
فريق من الدارسين الأسباب إلى العوامل الخارجية التي مصدرها البيئة الإقليمية والدولية 


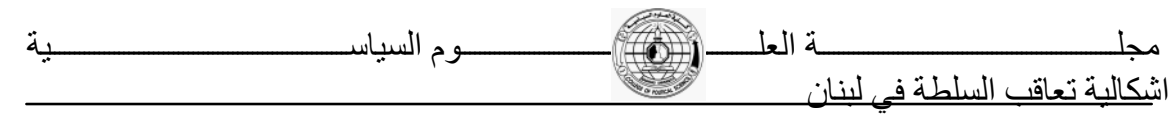

والتدخلات الأجنبية، ذهب فريق آخر للحديث عن أسباب نابعة من البيئة الداخلية اللبنانية بمختلف مكوناتها.

ومن خلال هذه الدراسة حاولنا إلقاء الضوء على اشكالية التعاقب على السلطة في لبنان

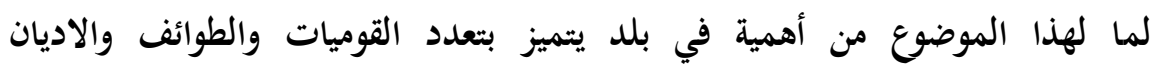

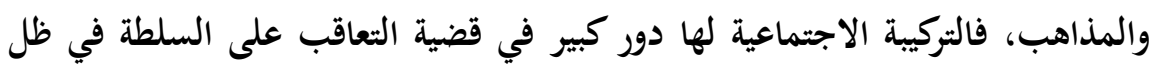
الديمقراطية التوافقية التي يرتكز عليها النظام السياسي في لبنان، اضافة الى البئئة البئل

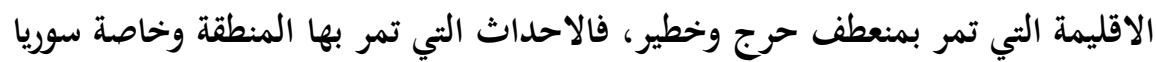
لا شك ان لها الاثر الكبير على مجمل العملية السياسية في لبنان.

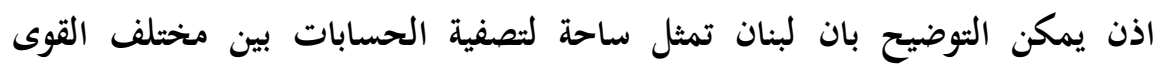

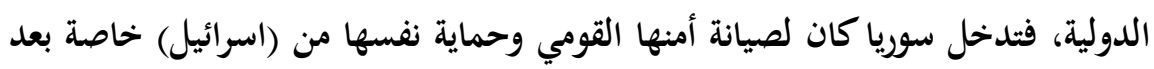

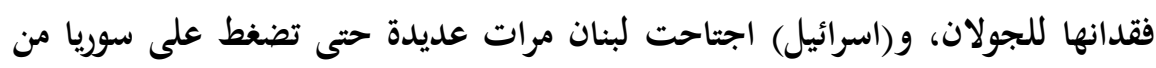

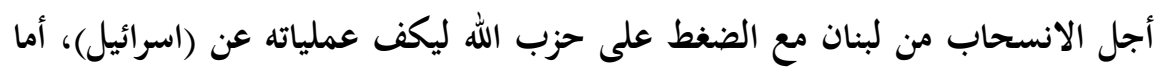

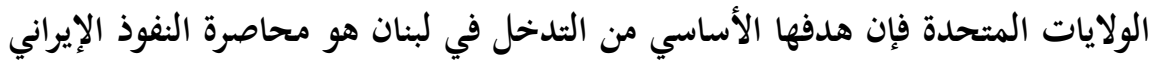

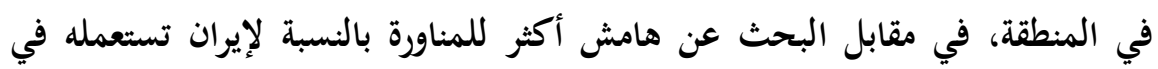
تجاذبها مع الولايات المتحدة و(اسرائيل) بخصوص قضية السلاح النووي.

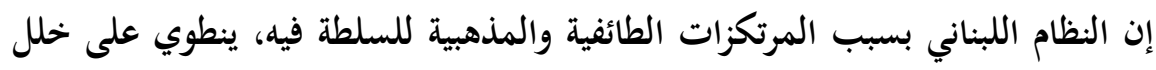

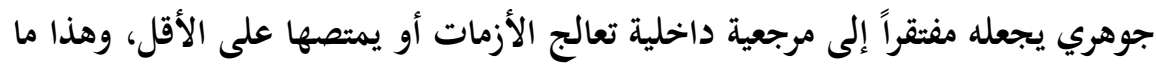

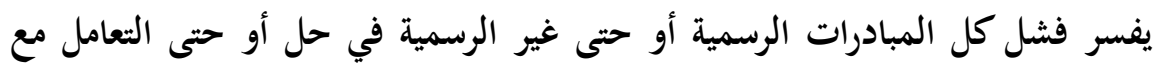

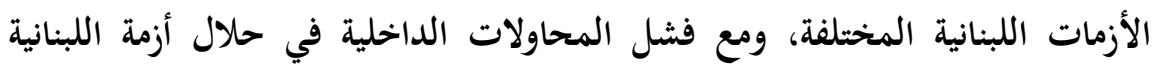

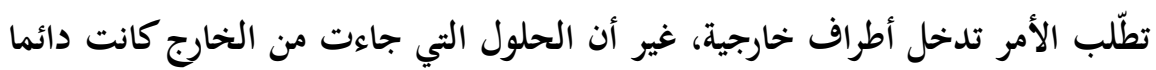

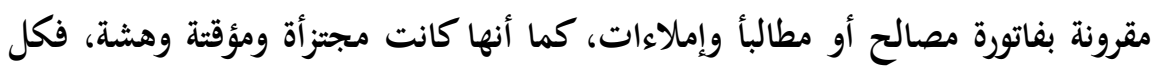

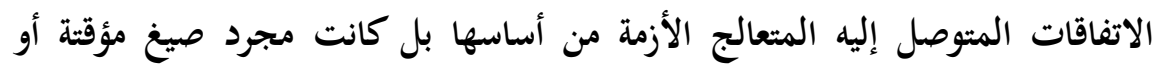
اتفاقات مرحلية لمعالجة زمنية محدودة.

\section{Thesuccession of power'sproblem in Lebanon}




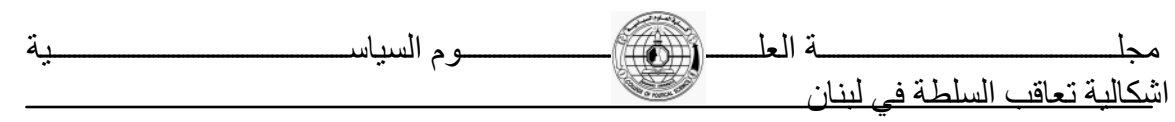

\section{Abstract}

Political power in Lebanon is a fundamental objective of any political organization, whether political party or political group. Thus, there is a conflict of power. There are two kinds of political conflict that are differentiated by the idea of legitimacy. The competition is in the political system when the agreement between the social forces is considered legitimate, and the conflict is on the political system when the agreement between these forces ceases to be legitimate and Are working to topple it and seek to establish an alternative system. Therefore, the succession of power in Lebanon is a result of the competition and political conflict, which is in turn a result of the large number of regional and international players on the Lebanesearena.

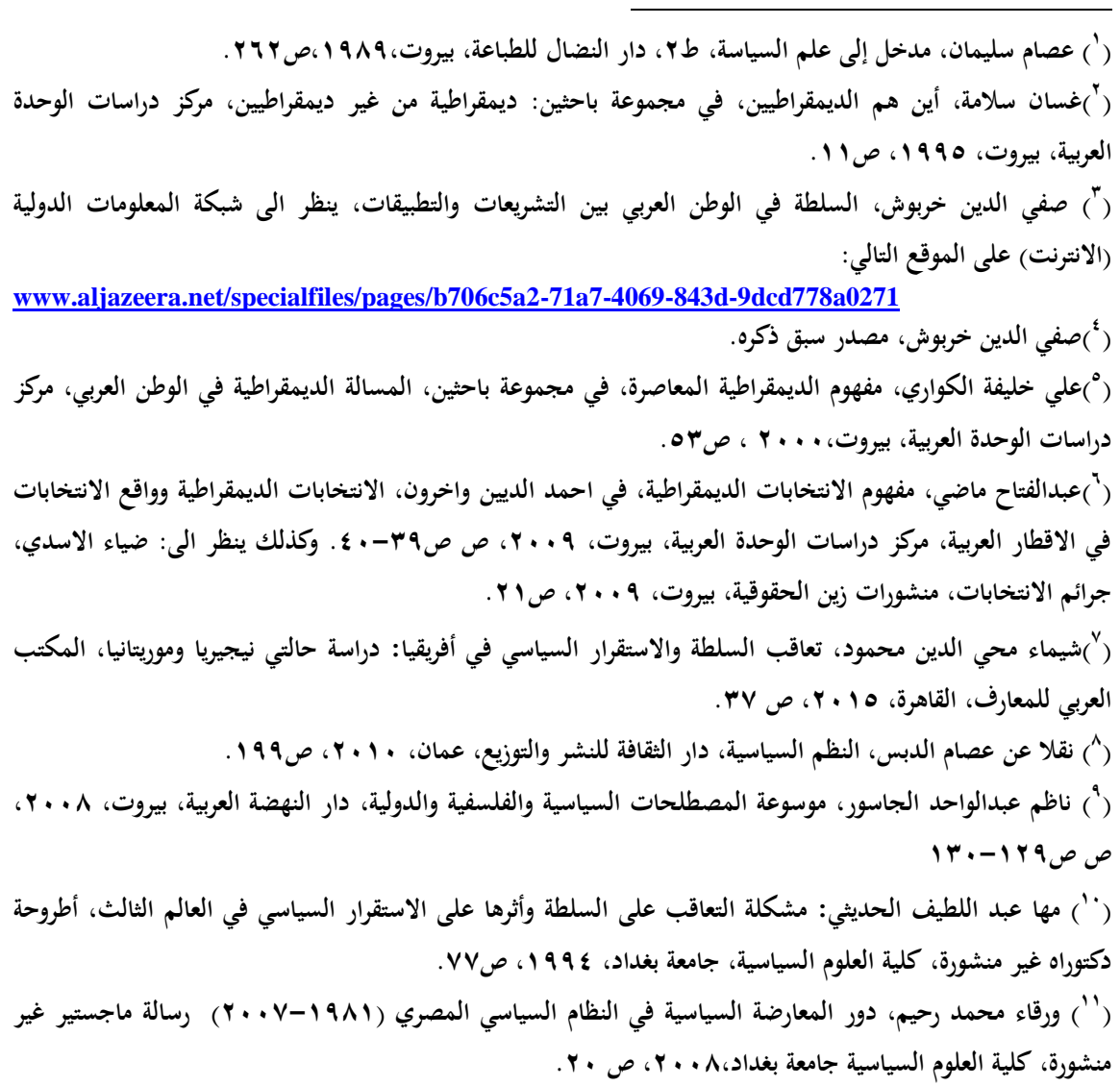




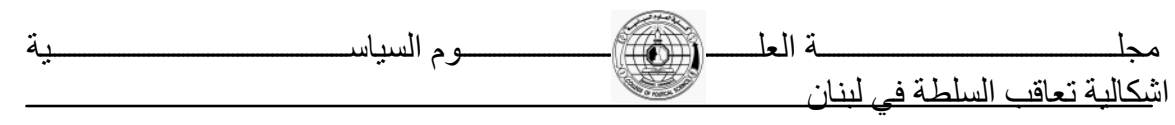

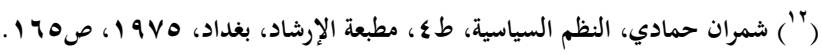

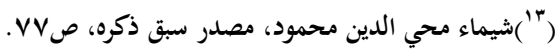

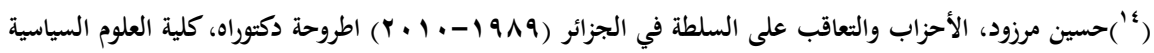

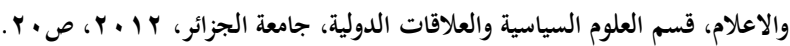

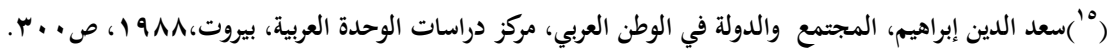

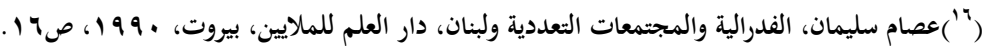

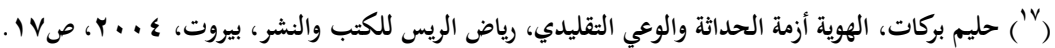

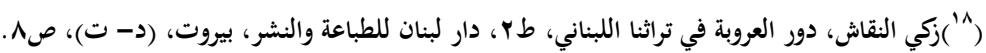

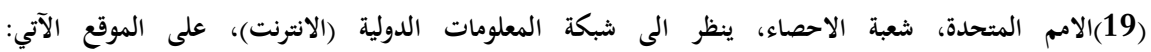
https://data.albankaldawli.org/indicator/SP.POP.TOTL

( • ( • (السكان في لبنان، مؤسسة فنك، :ينظر الى شبكة المعلومات الدولية (الانترنت) https://fanack.com/ar/lebanon/population/

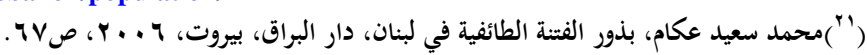

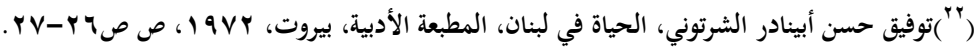

(rr)ملحم شاوول، مفهوم المواطنة في التجربة الغربية والتجربة اللبنانية، في جاك قبانجي (محرراً) إثكالية الدولة

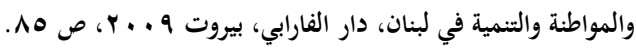

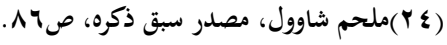
(Ө)(الخوند مسعود، الموسوعة التاريخية الجغرافية (لبنان)، الجزء السادس عشر، الشركة العالمية للموسوعات،

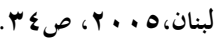

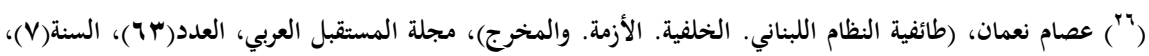

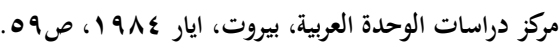
( ) (Yليم الحص، لبنان على المفترق، لبنان على المفترق، طب، المركز الاسلامي للإعلام والانماء، بيروت، Ir.

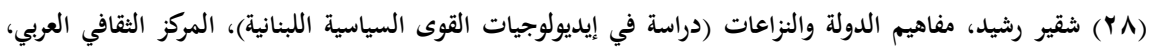

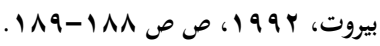

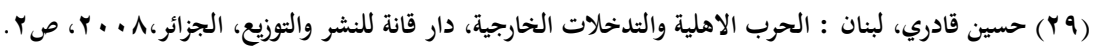
( • (ب) للمزيد عن النظام السياسي في لبنان ينظر الى: خالد قباني، النظام اللبناني بين ثوابت هو مستقبله، المؤسسة اللبنانية

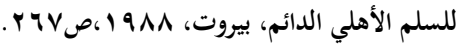

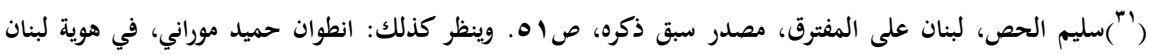

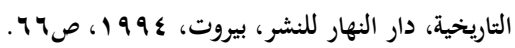

( )

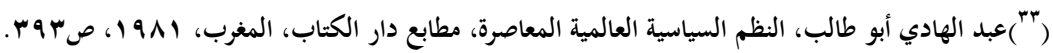




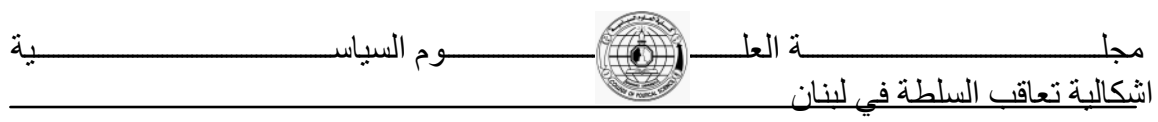

(") جوزيف مغيزل، في التشريع والاجتهادات القانونية، في حقوق الانسان وشؤون البيئة، في المسالة القومية، في القضية

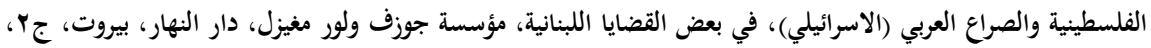
199V

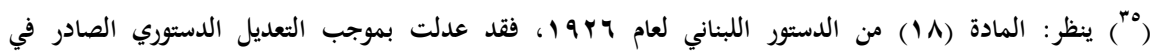

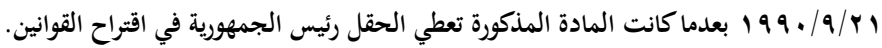

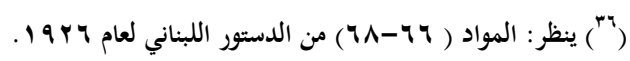

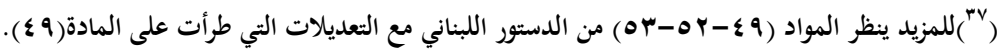

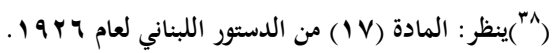

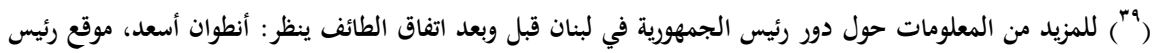

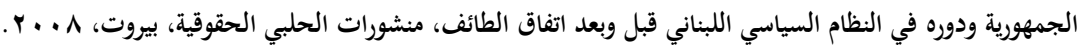

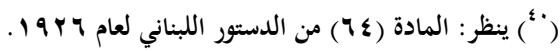

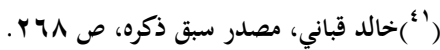

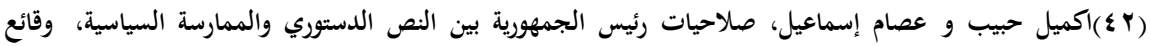

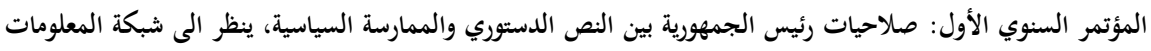

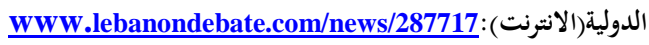

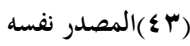
(") ؛ الدستور اللبناني كمحدد تاريخي للحرب الاهلية اللبنانية، ينظر الى شبكة المعلومات الدولية (الانترنت): http://www.mogatel.com

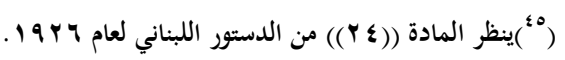

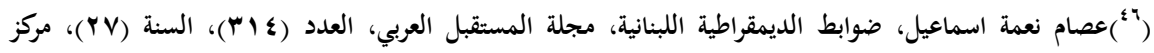

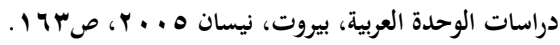
(")

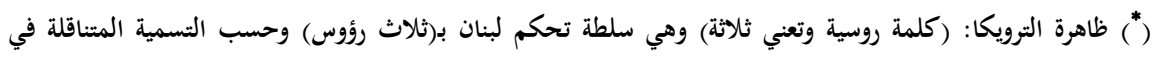

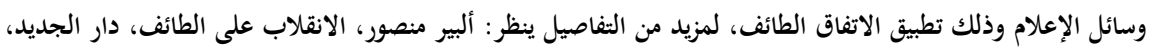

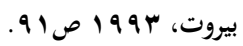

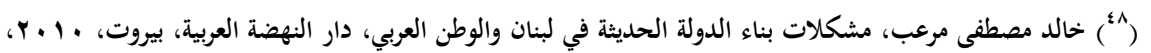

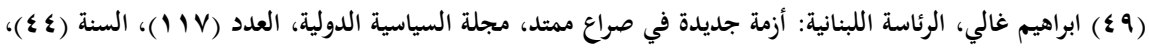

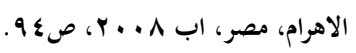

(•)علي مراد، الدستور اللبناني والسياسيين وعقدة الفراغ الرئاسي، ينظر الى شبكة المعلومات الدولية (الانترنت): https://lb.boell.org/ar/2014/07/04/ldstwr-llbnny-wlsysyyn-wqd-lfrg-lrysy

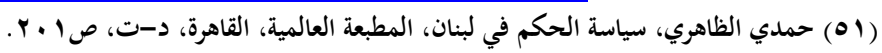

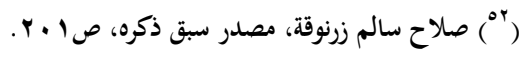




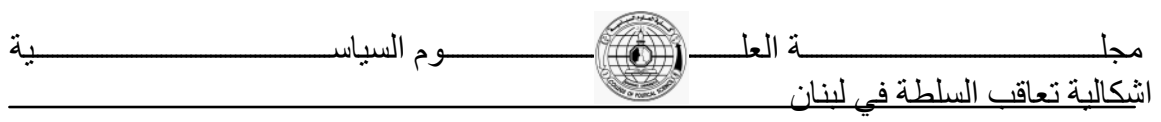

(Tه).حسين عطوي، تشكيل الحكومة اللبنانية.. وتحدي الإقرار بالتوازنات الجديدة، جريدة الوطن، ينظر الى شبكة

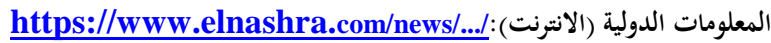
(0) (ه) حسين عطوي، مصدر سبق ذكره. (ه) خالد غزال، تشكيل الحكومة اللبنانية بين صراعات الداخل وتدخلات الخارج، ينظر الى شبكة المعلومات الدولية www.alhayat.com/.../ : الانترنت (ه7) منى جلال عواد، العامل الخارجي وإشكالية تعاقب السلطة في لبنان، محاضرات لطلبة الدراسات العليا، مرحلة

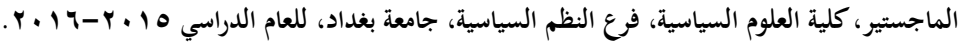

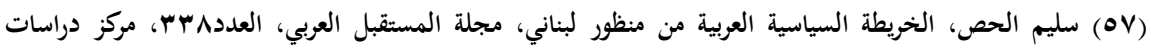

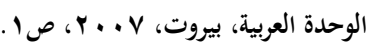
(ه1)

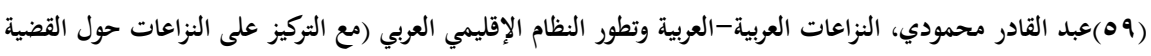

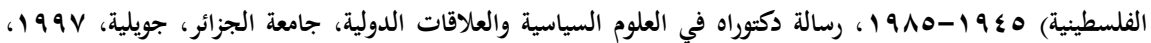

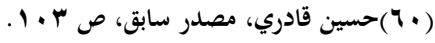

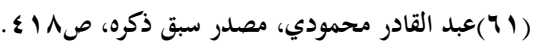

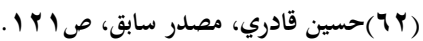

(") صالح محمود الكروي، لبنان بين تداعيات الانسحاب السوري والانتخابات التشريعية، مجلة المستقبل العببي، العدد

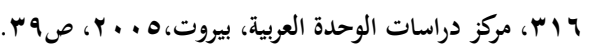

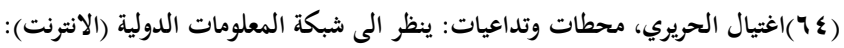
www.aljazeera.net/news/arabic/2010/8/9/

(10) سامح سعيد عبود، غروب شمس الانظمة العربية من نهايات القرن الماضي الى بدايات القرن الواحد والعشرين، مركز

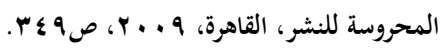

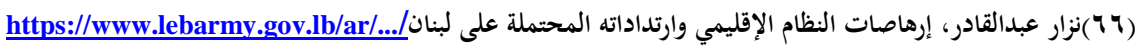

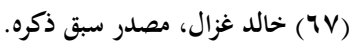

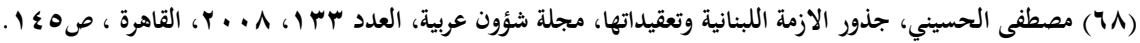

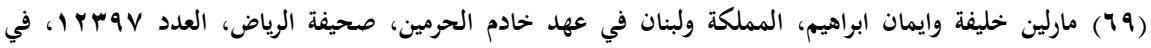

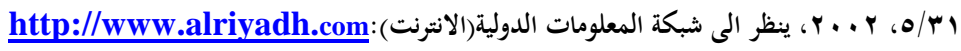

$$
\text { إل }
$$

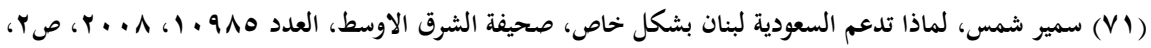

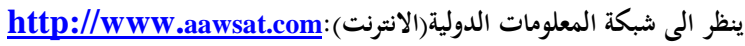

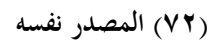

(VT)

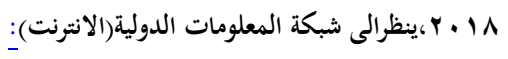




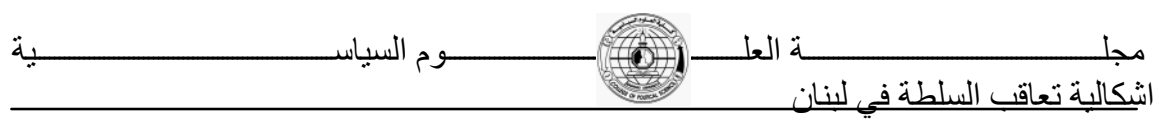

http://www.studies.aljazeera.net/ar/reports/2018/02/180207074333242.htm/

(") ولد اشرف ريفي في طرابلس، لبنان في الأول من ابريل \&9 9 19، درس علم اجتماع الجريمة في جامعة لبنان، ودرس

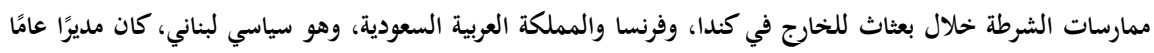

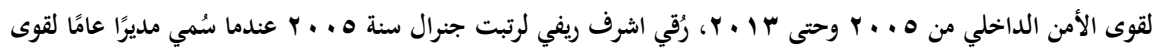

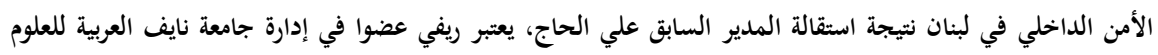

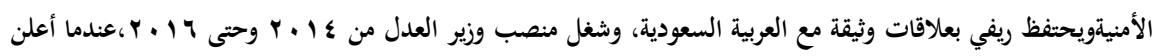

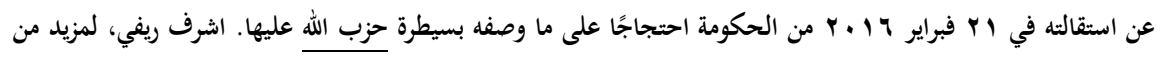
التفاصيل ينظر الى :ويكيبيديا الموسوعة الحرة، شبكة المعلومات الدولية (الانترنت): https://ar.wikipedia.org/wiki/

الانتخابات اللبنانية صفعة قوية للسياسة السعودية، ينظر الى شبكة المعوماتالدولية(الانترنت): (V ع https://www.al-sharq.com/.../2018/

(V0) محمود سويد، الجنوب اللبناني في مواجهة إسرائيل: • ه عاما من الصمود والمقاومة، مؤسسة الدراسات الفلسطينية،

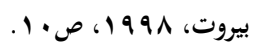

(TY) كميل منصور، الولايات المتحدة و(إسرائيل): العروة الأوثق، ترجمة نصير مروّة، مؤسسة الدراسات الفلسطينية،

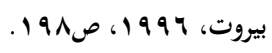

محمد الحموري، إمكانية ملاحقة جرائم الحرب (الإسرائيلية) في لبنان، مجلة المستقبل العببي،العددبrس،مركز

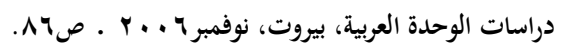

(VA)

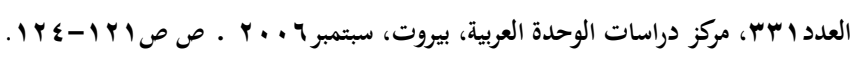

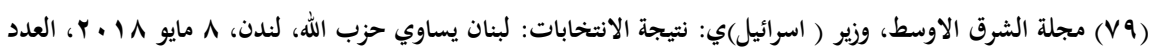

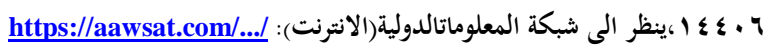

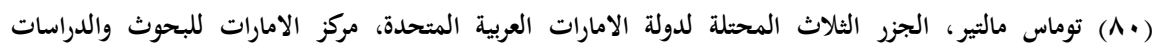

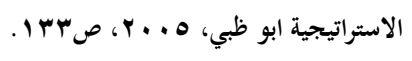

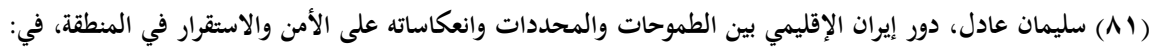

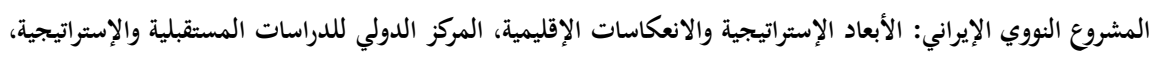

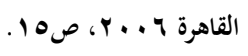

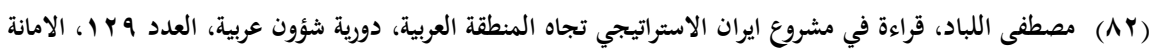

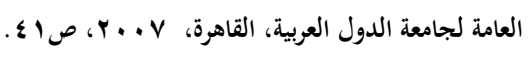

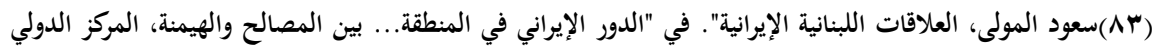

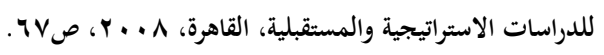

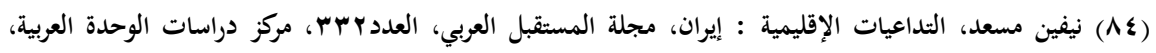

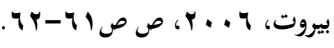

$$
\begin{aligned}
& \text { (^)خالد غزال، مصدر سبق ذكره. }
\end{aligned}
$$




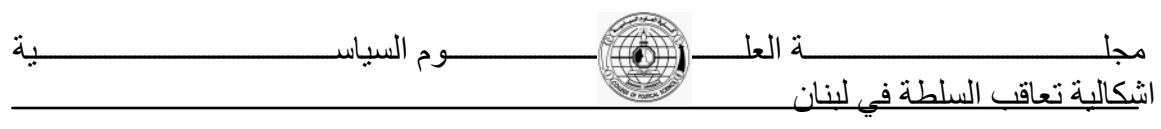

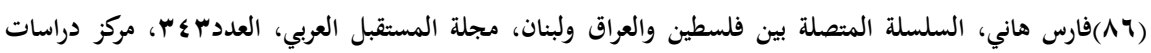

$$
\begin{aligned}
& \text { الوحدة العربية، بيروت، سبتمبر V . . Y، صVV. }
\end{aligned}
$$

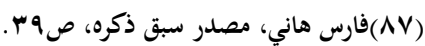

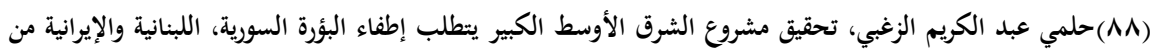

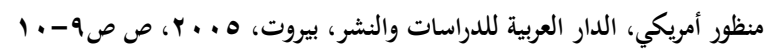

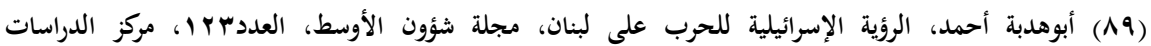

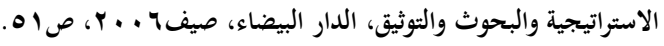

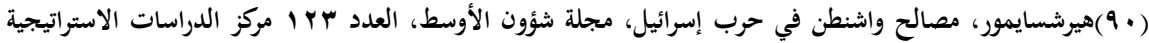

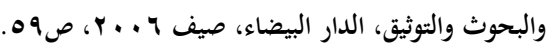

(") مجلة أمريكية: إدارة أوباما منعت ملاحقة "حزب الله، ترجمة منال حميد، تقرير منشور على شبكة المعلومات

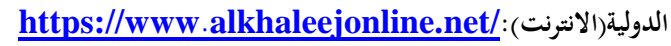

( (9) ادوار حداد، التطورات الأمريكية الإيرانية هل تؤثر على تشكيل الحكومة اللبنانية؟ ينظر الى :شبكة المعلومات

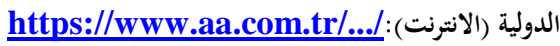

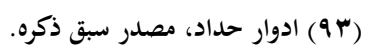

(צو) جورج ابو صعب، قراءة في حيثيات مأزق تشكيل الحكومة، ينظر الى شبكة المعلومات الدولية(الانترنت): https://www.lebanese-forces.com/.../read-the-reasons-for-the-dilemma-of-forming-a-g...

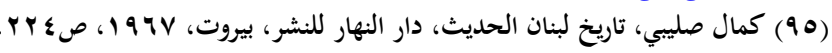

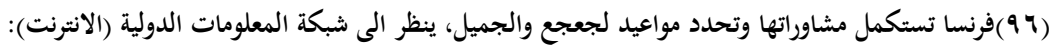

http://www.old.naharnet.com

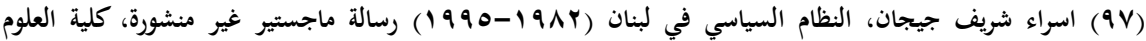

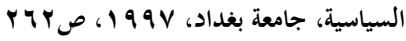

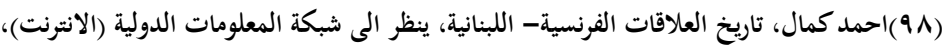

http://www.AIJazeera.net

(99) خالد فياض، حزب الله بين التماسك الايدلوجيوالبراجماتية السياسية، مجلة السياسة الدولية، العدد باج 1، مؤسسة

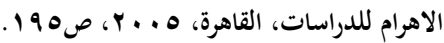

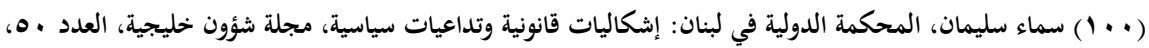

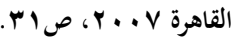

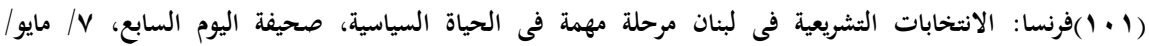

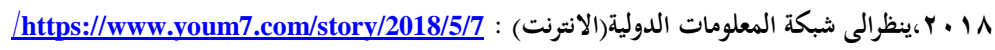

